Technical Task Plan No. AL93-20-03

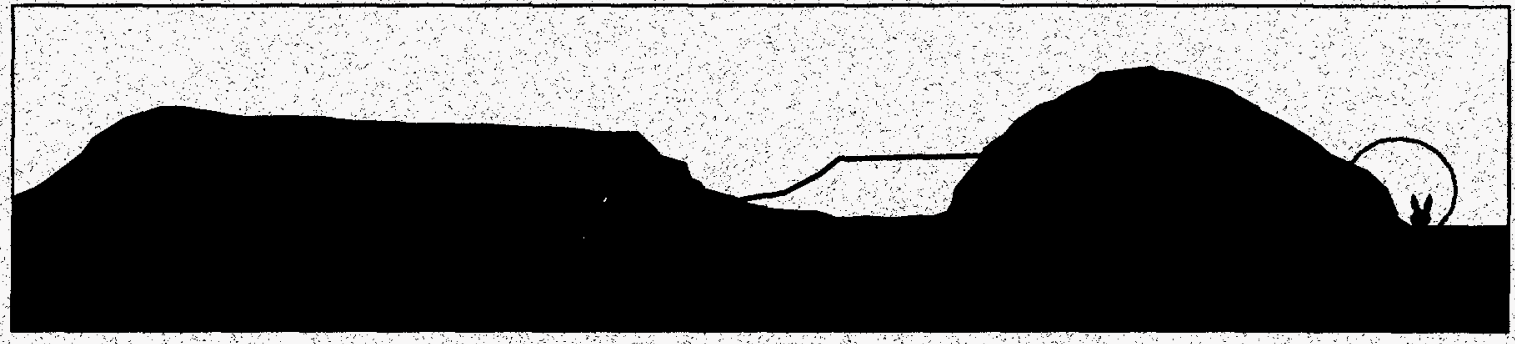

Rabbit Valley Geophysics Performance Evaluation Range

\title{
Geophysical Background and As-Built Target Characteristics
}

J. W. Allen

September 1994

\section{U.S. Department of Energy Grand Junction Projects Office Approved for public release, distribution is unlimited.}

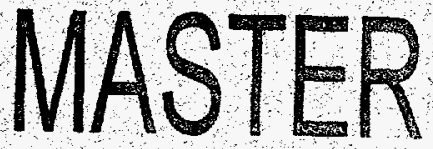

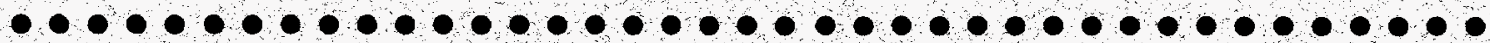
Work Performed Under DOE Contract No. DE-AC04-861012584 for the U.S. Department of Energy 
This report was prepared as an account of work sponsored by an agency of the United States Government. Neither the United States Government nor any agency thereof, nor any of their employees, makes any warranty, express or implied, or assumes any legal liability or responsibility for the accuracy, completeness, or usefulness of any information, apparatus, product, or process disclosed in this report, or represents that its use would not infringe privately owned rights. Reference herein to any specific commercial product, process, or service by trade name, trademark, manufacturer, or otherwise, does not necessarily constitute or imply its endorsement, recommendation, or favoring by the United States Government or any agency thereof. The views and opinions of authors expressed herein do not necessarily state or reflect those of the United States Government or any agency thereof. 
DOE/D/12584-195

GJPO-GP-13

Technical Task Plan No. AL932003

Static Cell As-Builts and Background

Characteristics for

Rabbit Valley Geophysics Performance

Evaluation Range

J. W. Allen

September 1994

U.S. Department of Energy

Grand Junction Projects Office

RUST Geotech Inc.

Grand Junction, Colorado

Approved for public release; distribution is unlimited. 


\section{DISCLAIMER}

Portions of this document may be illegible in electronic image products. Images are produced from the best available original document. 



\section{Contents}

Executive Summary $\ldots \ldots \ldots \ldots \ldots \ldots \ldots \ldots \ldots \ldots \ldots \ldots \ldots$

I. Introduction $\ldots \ldots \ldots \ldots \ldots \ldots \ldots \ldots \ldots \ldots \ldots \ldots \ldots$

II. Rabbit Valley Site Description $\ldots \ldots \ldots \ldots \ldots \ldots \ldots \ldots \ldots \ldots \ldots \ldots$

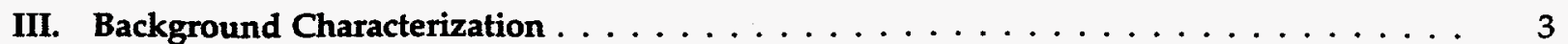

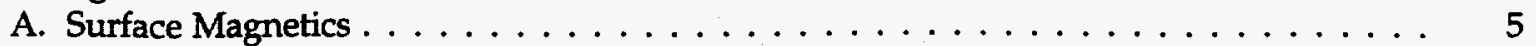

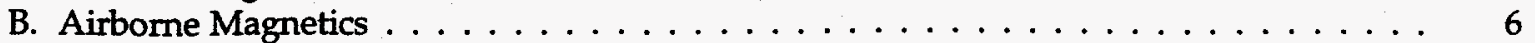

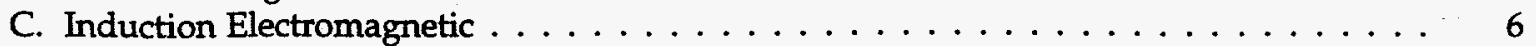

D. Very Low Frequency Electromagnetic . . . . . . . . . . . . . . . . . . 7

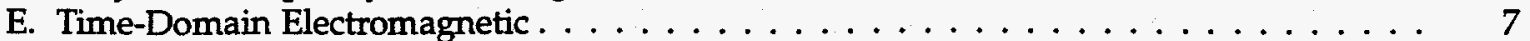

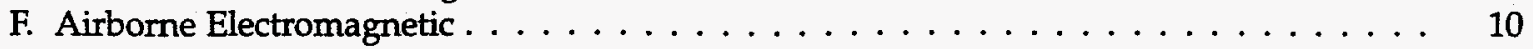

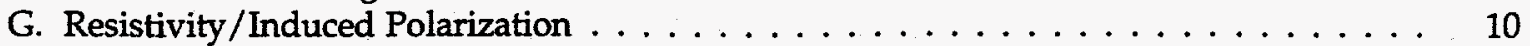

H. Ground-Penetrating Radar . . . . . . . . . . . . . . . . . 11

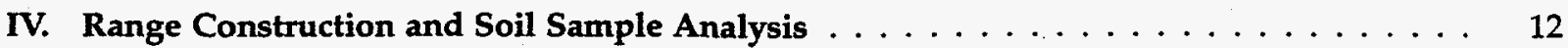

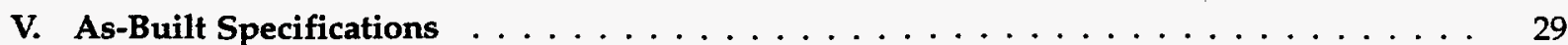

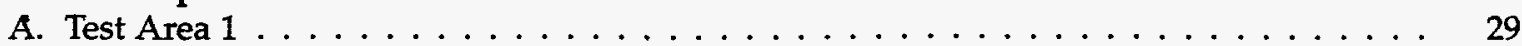

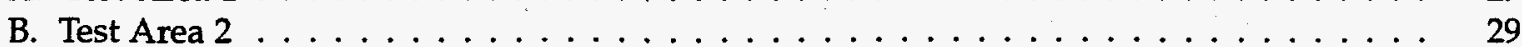

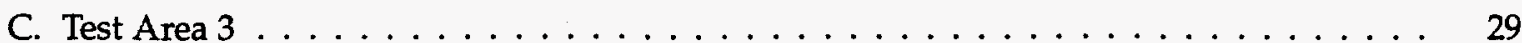

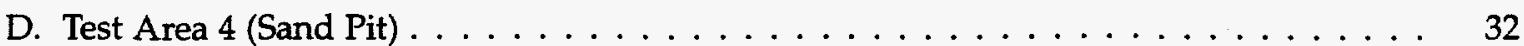

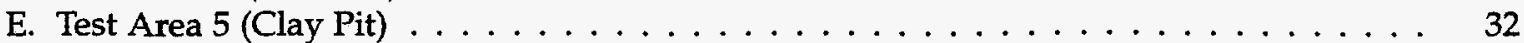

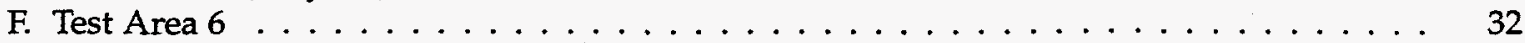

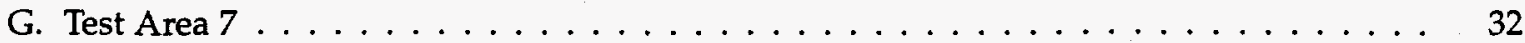

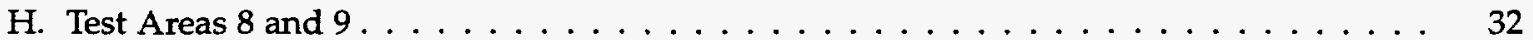

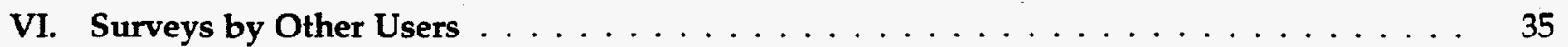

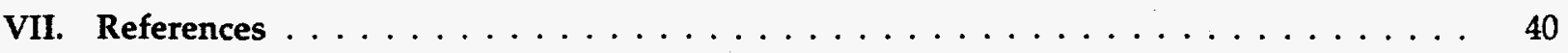

VIII. Acknowledgments $\ldots \ldots \ldots \ldots \ldots \ldots \ldots \ldots \ldots \ldots \ldots \ldots \ldots \ldots$

Appendix A. Maps of Test Areas $\ldots \ldots \ldots \ldots \ldots \ldots \ldots \ldots \ldots \ldots \ldots \ldots \ldots$

Appendix B. Soil Sample Analysis Report $\ldots \ldots \ldots \ldots \ldots \ldots \ldots \ldots \ldots \ldots \ldots$ B-1

Figure $\quad$ 1. Location of Rabbit Valley GPER in Western Colorado . . . . . . . . . . . . 2

2. Area Map Showing Route to Rabbit Valley GPER . . . . . . . . . . . . . . . . 2

3. Rabbit Valley GPER Site . . . . . . . . . . . . . . . . . 3

4. Rabbit Valley GPER Test Area and Target Layout . . . . . . . . . . . . . 4

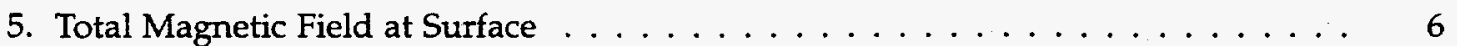

6. Vertical Gradient of Magnetic Field at Surface . . . . . . . . . . . . 7

7. Total Magnetic Field at 50 Meters Above Surface $\ldots \ldots \ldots \ldots$

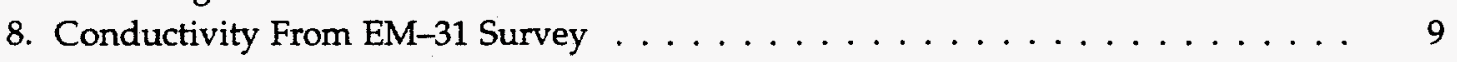

9. In-Phase From EM-31 Survey . . . . . . . . . . . . . . . . . 10

10. In-Phase Anomaly Over Large Steel Culvert . . . . . . . . . . . . . . . . 11

11. Field Strength of $21.4-\mathrm{kHz}$ VLF-EM $\ldots \ldots \ldots \ldots \ldots \ldots \ldots$

12. Apparent Early-Time Conductivity From TDEM Survey Before Construction . . . . 13

13. Apparent Medium-Time Conductivity From TDEM Survey . . . . . . . . . . . 14

14. Apparent Late-Time Conductivity From TDEM Survey . . . . . . . . . . . . . . 15

15. Apparent Resistivity at $4165 \mathrm{~Hz}$ From Airborne EM Survey . . . . . . . . . . 16

16. Apparent Resistivity at $35.6 \mathrm{kHz}$ From Airborne EM Survey . . . . . . . . . . . 17 


\section{Figures (continued)}

Figure 17. Apparent Resistivity From Surface R/IP Survey $\ldots \ldots \ldots \ldots \ldots \ldots \ldots$

18. Induced Polarization From Surface $\mathrm{R} / \mathrm{IP}$ Survey $\ldots \ldots \ldots \ldots \ldots \ldots$

19. GPR Survey at $80 \mathrm{MHz}$ Along Line $440 \mathrm{~S} \ldots \ldots \ldots \ldots \ldots$

20. $500-\mathrm{MHz}$ GPR Survey Over Empty Concrete Vault $\ldots \ldots \ldots \ldots \ldots \ldots$

21. $500-\mathrm{MHz}$ GPR Survey Over PVC Pipe Cache . . . . . . . . . . . . . . 21

22. Construction of Clay Pit (Area 5) Showing Pit Boundary . . . . . . . . . 22

23. Construction of Sand Pit (Area 4) Showing Excavator in Action . . . . . . . . 22

24. Dust Control in Action at Sand Pit . . . . . . . . . . . . . 23

25. Placement of Clay Layer in Clay Pit $\ldots \ldots \ldots \ldots \ldots \ldots \ldots \ldots$

26. Placement of Metal-Sheet Target in Clay Pit . . . . . . . . . . . . . 24

27. Emplacing $0.5-$ Meter Steel Sphere in Area $6 \ldots \ldots \ldots \ldots \ldots$

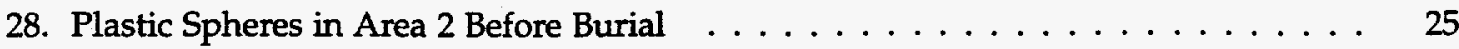

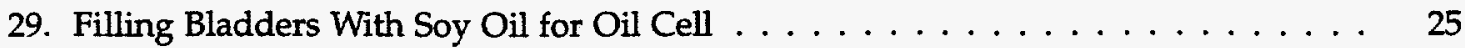

30. Wood Cell Before Burial . . . . . . . . . . . . . . . . . . . 26

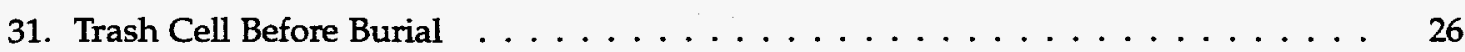

32. Recontoured Surface of Sand Pit . . . . . . . . . . . . . . . 27

33. Deployment Pattern of Targets in Test Area $2 \ldots \ldots \ldots$. . . . . . . . . . . . 29

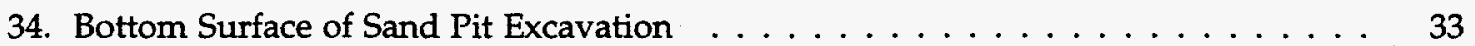

35. Upper Surface of Sand Pit After Recontouring . . . . . . . . . . . . . . 34

36. Bottom Surface of Clay Pit Excavation . . . . . . . . . . . . . 36

37. Upper Surface of Clay Pit After Recontouring . . . . . . . . . . . . . . . . . 37

A-1. Rabbit Valley GPER Area $1 \ldots \ldots \ldots \ldots \ldots \ldots \ldots \ldots$. . . . . . . . . .

A-2. Rabbit Valley GPER Area $2 \ldots \ldots \ldots \ldots \ldots \ldots \ldots \ldots \ldots \ldots$. . . . . . . . .

A-3. Rabbit Valley GPER Area $3 \ldots \ldots \ldots \ldots \ldots \ldots \ldots \ldots \ldots$. . . . . . . . . . . . . . . . . . . . . . . . .

A-4. Rabbit Valley GPER Area $4 \ldots \ldots \ldots \ldots \ldots \ldots \ldots \ldots \ldots$

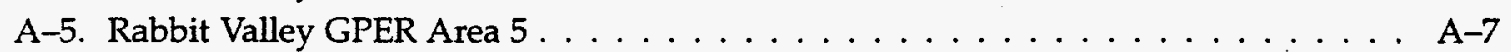

A-6. Rabbit Valley GPER Area $6 \ldots \ldots \ldots \ldots \ldots \ldots \ldots \ldots \ldots$ A . . . . . . . . . . . . . . . . . . . . . . . . .

A-7. Rabbit Valley GPER Area $7 \ldots \ldots \ldots \ldots \ldots \ldots \ldots \ldots \ldots \ldots$

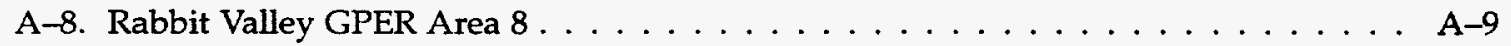

A-9. Rabbit Valley GPER Area $9 \ldots \ldots \ldots \ldots \ldots \ldots \ldots \ldots \ldots$. . . . . . . . . . . .

\section{Tables}

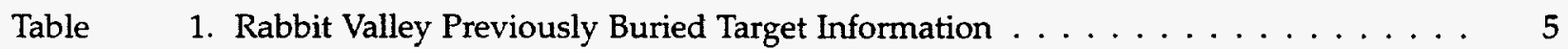

2. RV GPER Site Background Characteristics . . . . . . . . . . . . . . . 5

3. Analytical Results for Soil Samples . . . . . . . . . . . . . . . 28

4. Test Area 1 Target Information . . . . . . . . . . . . . . . . 30

5. Test Area 2 Target Information . . . . . . . . . . . . . . . . 30

6. Test Area 3 Target Information ... . . . . . . . . . . . . . . . . . 31

7. Test Area 4 Target Information . . . . . . . . . . . . . . . . . 35

8. Test Area 5 Target Information . . . . . . . . . . . . . . . . 38

9. Test Area 6 Target Information . . . . . . . . . . . . . . . . . . . . . . 39

10. Test Area 7 Target Information . . . . . . . . . . . . . . . . . . . . . . . . . . . . . . . . . . . . . .

11. Test Areas 8 and 9 Target Information . . . . . . . . . . . . . 40 


\section{Executive Summary}

The U.S. Department of Energy (DOE) Grand Junction Projects Office (GJPO) has provided a facility for DOE, other Government agencies, and the private sector to evaluate and document the utility of specific geophysical measurement techniques for detecting and defining cultural and environmental targets. This facility is the Rabbit Valley Geophysics Performance Evaluation Range (GPER), which includes test cells in the high-desert terrain of Rabbit Valley, 30 miles west of Grand Junction, Colorado, and test cells and calibration models at the DOE-GJPO facility in Grand Junction. The GPER provides facilities to evaluate the performance of instrumentation systems used in a variety of geophysical measurement methods. It permits objective and comprehensive quantification of the relationships among measured geophysical data, computer-modeled responses, and well-defined target and environmental parameters for individual test cells.

Geophysical surveys prior to the fiscal year (FY) 1994 construction of new test cells showed the primary test area to be relatively homogeneous and free from natural or man-made artifacts, which would generate spurious responses in performance evaluation data. Construction of nine new cell areas in Rabbit Valley was completed in June 1994 and resulted in the emplacement of approximately 150 discrete targets selected for their physical and electrical properties. These targets and their geophysical environment provide a broad range of performance evaluation parameters from "very easy to detect" to "challenging to the most advanced systems."

The Rabbit Valley GPER is user friendly; access requires no security clearance or special permission, and user support is available when requested. Data from previous surveys have been archived and are available for review and use by all users who agree to share their data. During FY 1994, users from Government agencies, private industry, and academia conducted various surveys at the Rabbit Valley site and expressed enthusiasm in their praise of the project. 
I

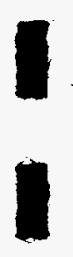

I

I

I

I

I

I

I

,

I

I

I

I

I

I

I

I 


\section{Introduction}

The U.S. Department of Energy (DOE) Office of Technology Development tasked the Grand Junction Projects Office (GJPO) to provide a facility suitable for evaluation and documentation of specific geophysical measurement techniques for detecting and defining cultural and environmental targets. Intended users of the facility are DOE Office of Waste Management and Office of Environmental Restoration programs, DOE Operations Offices, other Government agencies (U.S. Department of Defense, U.S. Geological Survey, U.S. Bureau of Reclamation, U.S. Bureau of Mines, etc.), and the private sector. This facility-the Rabbit Valley Geophysics Performance Evaluation Range (GPER)-includes test cells in the high-desert terrain of Rabbit Valley, 30 miles west of Grand Junction, Colorado, and test cells and calibration models at the DOE-GJPO facility in Grand Junction. The GPER provides facilities to evaluate the performance of instrumentation systems used in a variety of geophysical measurement methods and permits objective and comprehensive quantification of the relationships among measured geophysical data, computer modeled responses, and well-defined target and environmental parameters for individual test cells.

Use of nonintrusive investigative techniques represents a significant improvement over intrusive characterization methods, such as drilling or excavation, because there is no danger of exposing personnel to possible hazardous materials and no risk of releasing or spreading contamination through the characterization activity. Nonintrusive geophysical techniques provide the ability to infer near-surface structure and waste characteristics from measurements of physical properties associated with those targets.

The Rabbit Valley GPER provides known parameters against which the performance of nonintrusive geophysical instruments or methods can be assessed. Comparison of the responses obtained over undisturbed earth (background characteristics) with the responses observed after construction of the test cells determines the response contribution of the materials placed in the GPER cells. Quantification of this response contribution allows a direct assessment of precision and accuracy of geophysical instrumentation and furnishes performance criteria for development or adaptation of emerging geophysical methods and technologies.

\section{Rabbit Valley Site Description}

The Rabbit Valley site is an 80-acre tract of public land administered by the Bureau of Land Management (BLM). It is authorized for use as a geophysical test site under an Interagency Agreement between BLM and DOE-GJPO and has been approved for a Categorical Exclusion under the National Environmental Policy Act (NEPA). No aboveground structures are employed in the Rabbit Valley GPER, and all geophysical targets have been placed underground. All construction activities at the site were conducted in accordance with approved Health and Safety Plans and were conducted to minimize damage or permanent changes to the natural terrain. Interim remediation includes recontouring and scarifying the surface over test cells, with revegetation to be conducted at the most effective time of year.

The Rabbit Valley area is a multiple land-use area and is a favorite area for recreational bikers, campers, and four-wheel-drive vehicles. It is also used for grazing of cattle and sheep in the winter and spring. Signs posted at the road access points to the site request that vehicles remain on roads designated by the BLM for vehicle use, unless otherwise authorized. This restriction minimizes the possibility of damage to the terrain, to the survey grids, and to the target burial areas.

Figure 1 shows the location of the Rabbit Valley GPER in relation to Colorado and surrounding States. Figure 2 shows the route from Grand Junction to the Rabbit Valley Site via U.S. Interstate 70 to the Rabbit Valley exit, thence south and east via BLM gravel roads to the GPER. Figure 3 is a view looking across the site to the southwest from the northeast quarter-section corner, which is the reference for the site survey grids. The majority of the recently constructed static test cells are located in the flat area near the center of the photo, while several previously implanted cells are located in the right foreground of the photo. 


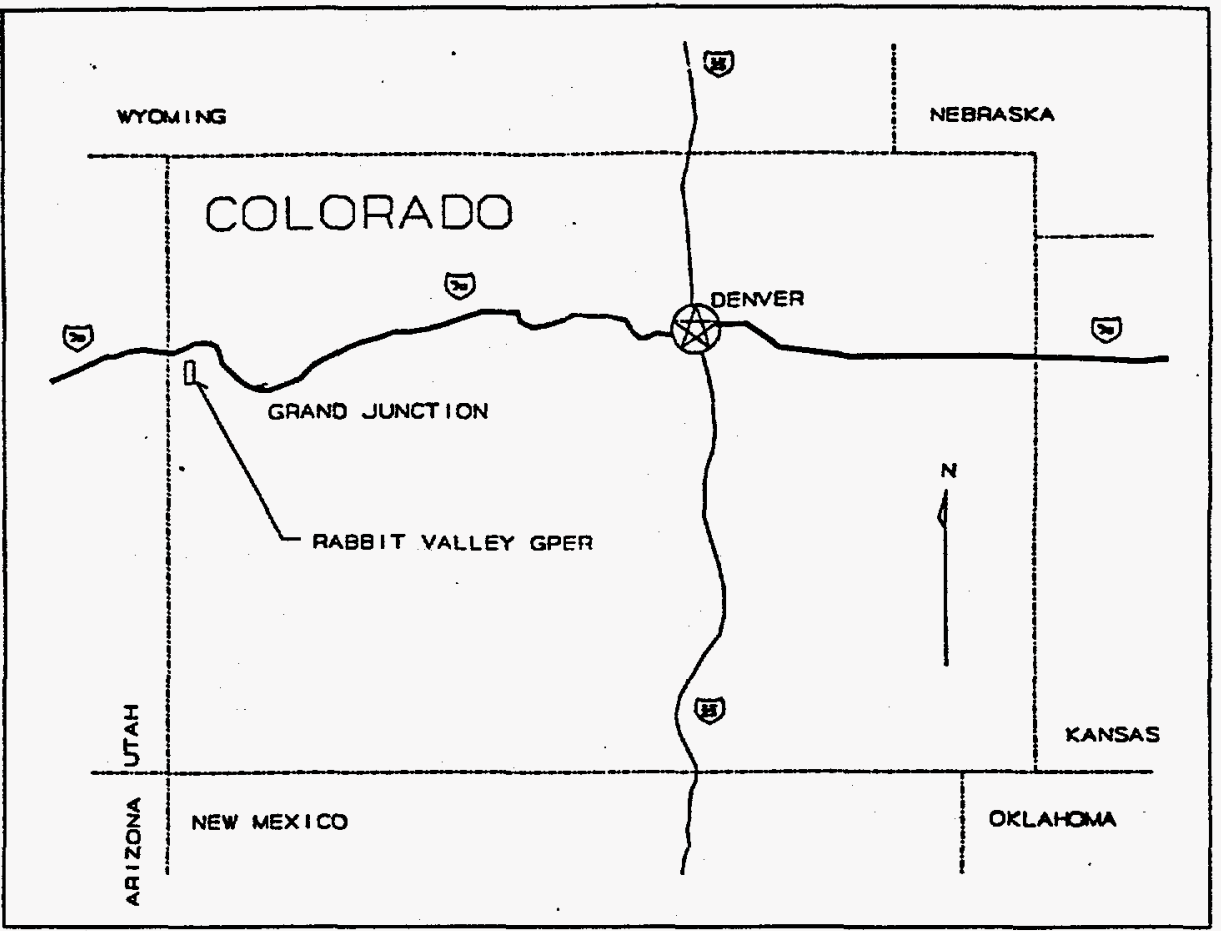

Figure 1. Location of Rabbit Valley GPER in Western Colorado

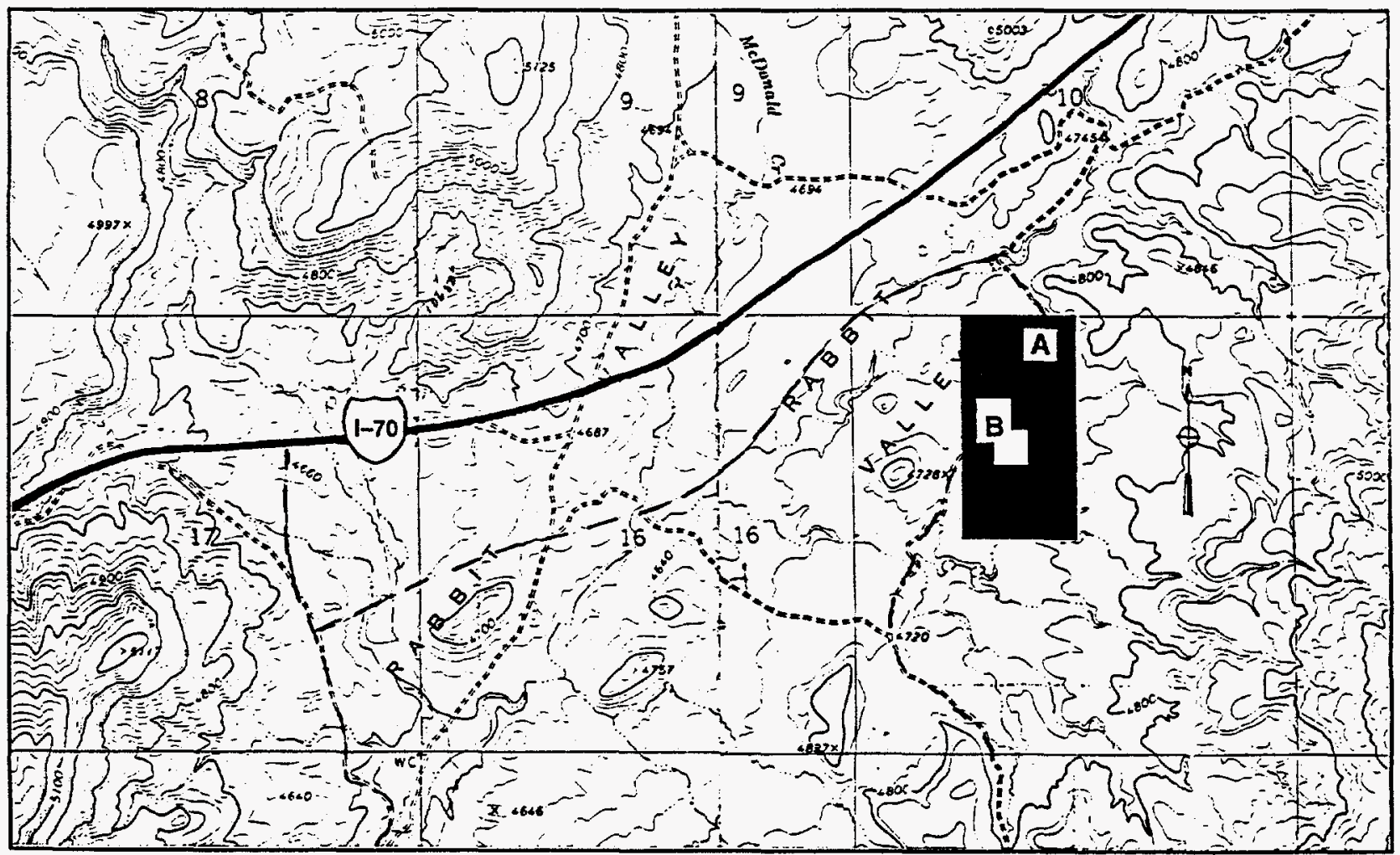

Figure 2. Area Map Showing Route to Rabbit Valley GPER 


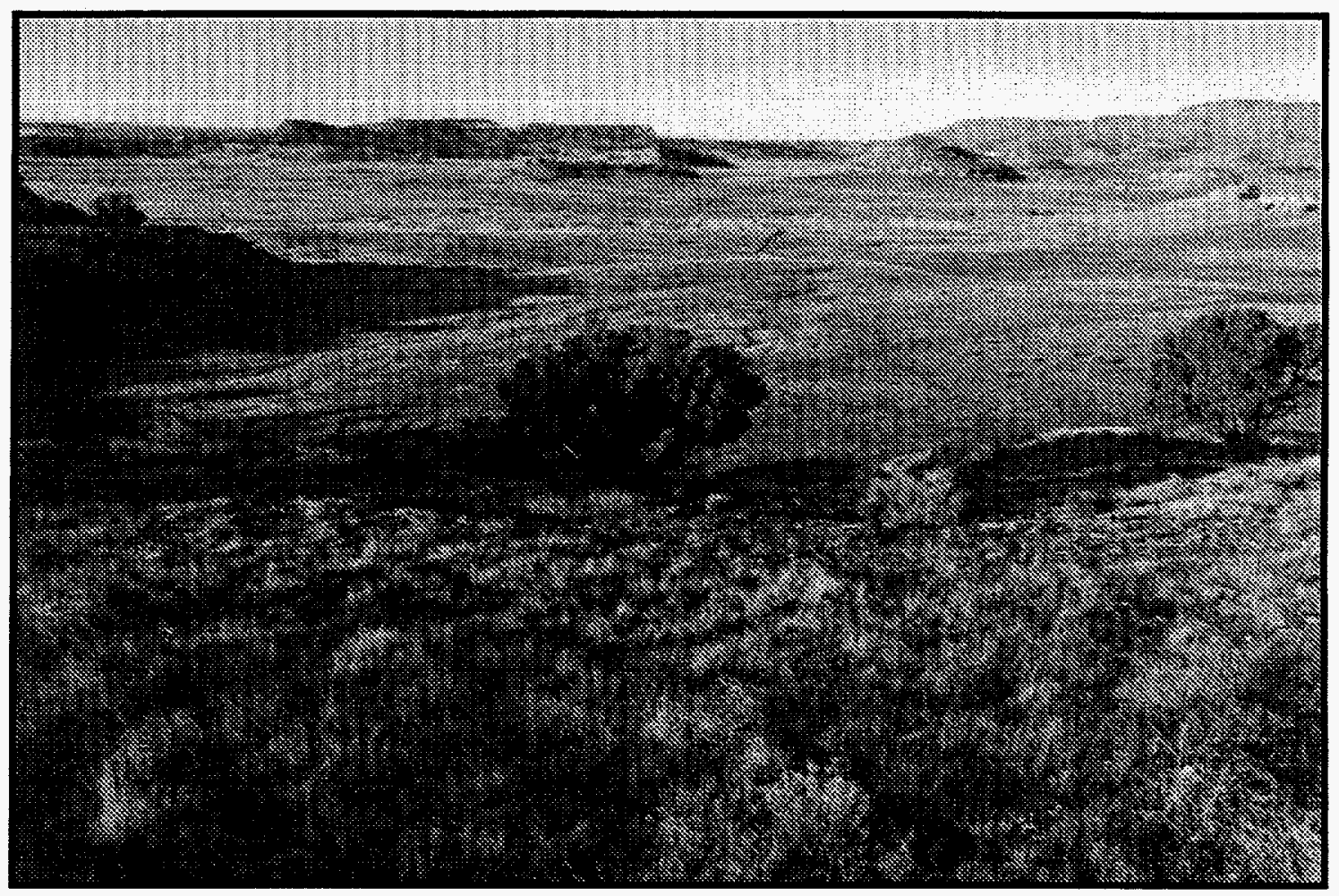

Figure 3. Rabbit Valley GPER Site

Figure 4 shows the relative layout of the static cells with grid coordinates relative to the northeast quarter-section corner. The recently constructed test cells extend over an area of approximately 20 acres to provide isolation between cells and adequate area around each cell for characterization of the background environment. Appendix A includes detailed maps showing target locations within the cells; Section V, "As-Built Specifications," presents target and cell descriptions.

\section{Background Characterization}

Geophysical surveys were conducted during the first quarter of fiscal year 1994 to characterize the natural background environment before construction of the test cells. Survey results showed the primary test area to be relatively homogeneous and free from natural or man-made artifacts that would generate spurious responses in performance evaluation data. Target responses over the previously implanted targets were characterized during the background surveys and during surveys conducted by several other users. Background surveys were performed with surface geophysical methods, including inductive electromagnetic (IEM) with a Geonics EM-31, magnetic/very low frequency electromagnetic (MAG/VLF-EM) with an EDA OMNI-PLUS, resistivity/induced polarization (R/IP) with an Androtex TDR-6 receiver and a Phoenix IPT-1 transmitter, time-domain electromagnetic (TDEM) with a Geonics TEM-47 system, and ground-penetrating radar (GPR) with a GSSI/SIR-8 system. An airborne magnetic/electromagnetic survey was also conducted by a subcontractor, High Sense Geophysics Ltd. The airborne equipment included a Ranger 4 EM system, a Picodas PDAS-1000 magnetometer with a Scintrex H8 cesium-vapor sensor, a global positioning system, a radar altimeter, and a video flight-path camera and recorder.

Surface surveys were conducted in two areas of the Rabbit Valley 80-acre site. The two areas were previously surveyed and gridded on 10-meter $(\mathrm{m})$ station centers by RUST Geotech Inc.* land surveyors. Oak hubs were emplaced at the $10-\mathrm{m}$ grid nodes. Measurement stations spaced $4 \mathrm{~m}$ apart

\footnotetext{
*Rust Geotech Inc. (Geotech) is the operating contractor for the GJPO
} 


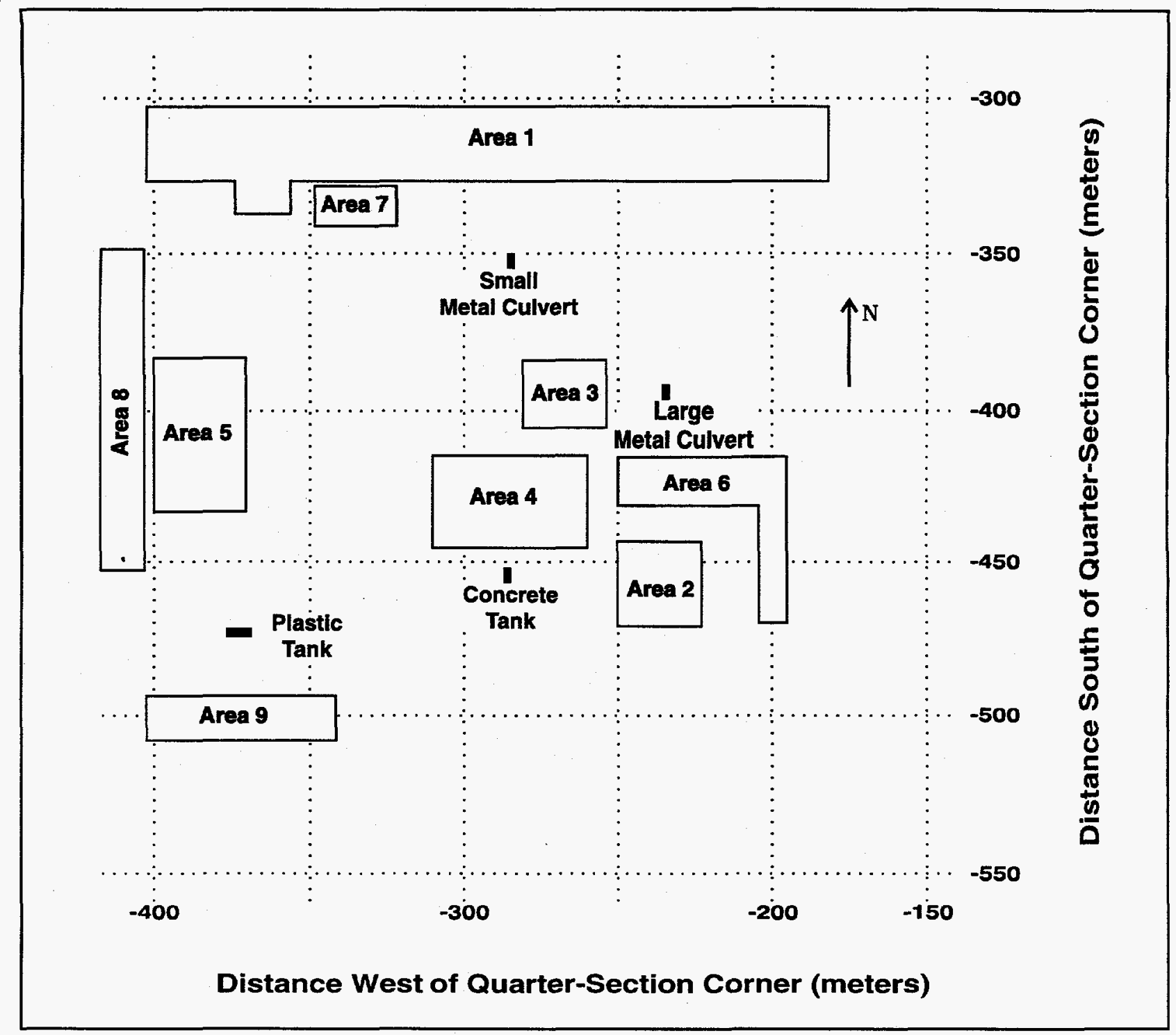

Figure 4. Rabbit Valley GPER Test Area and Target Layout

were superimposed over the surveyed grid by geophysical survey personnel, and data were collected at more than 4,800 stations for each method used.

Area $A$ is near the northeast corner of the site and includes previously buried nonmagnetic targets (see Table 1). The portion of Area A that was surveyed extends from station 50 West, 0 North $(-50,0)$ to 150 West, 100 South $(-150,-100)$. Area B is near the center of the 80 -acre tract and extends from 100 West to 400 West and from 300 South to 550 South.

Area B contains both magnetic and nonmagnetic targets that were buried previously (see Table 1). The exact boundaries of the GPER are somewhat irregular because of topographical restrictions. Figure 2 shows the relative locations of the two areas surveyed. The airborne surveys covered the entire 80 -acre tract using 50 east-west flight lines spaced $16 \mathrm{~m}$ apart. North-south tie lines were flown along the edges of the tract.

Table 2 presents a summary of the primary results of the background characterization surveys. The overall character of the data suggests a relatively homogeneous environment over the two areas of interest with only small variations in magnetic and resistive/conductive parameters. Surface and 
Table 1. Rabbit Valley Previously Buried Target Information

\begin{tabular}{|c|c|c|c|}
\hline Target Description & Location & Orientation/Depth & Primary Use \\
\hline $\begin{array}{l}\text { Nonreinforced concrete vault } \\
\text { and removable wood lid } \\
\text { covered with } 0.3 \mathrm{~m} \text { of earth } \\
\text { Width: } 1.5 \mathrm{~m} \\
\text { Height: } 1.2 \mathrm{~m}\end{array}$ & $-180,-80$ & Axis vertical/0.3 $\mathrm{m}$ to top & $\begin{array}{l}\text { GPR, } R / I P \text {, seismic, gravity, } \\
\text { magnetic, and EM }\end{array}$ \\
\hline $\begin{array}{l}\text { Plastic box filled with paraffin } \\
\text { Length: } 0.8 \mathrm{~m} \\
\text { Width: } 0.5 \mathrm{~m} \\
\text { Height: } 0.5 \mathrm{~m}\end{array}$ & $-160,-30$ & Axis horizontal/0.25 $\mathrm{m}$ to top & GPR, R/IP, and seismic \\
\hline $\begin{array}{l}\text { Corrugated steel culvert } \\
\text { Length: } 1.2 \mathrm{~m} \\
\text { Width: } 0.6 \mathrm{~m}\end{array}$ & $-285,-355$ & $\begin{array}{l}\text { Axis horizontal, oriented } \\
\text { north-south } / 2 \mathrm{~m} \text { to top }\end{array}$ & $\begin{array}{l}\text { GPR, TDEM, magnetic, } \\
\text { seismic, R/IP, and gravity }\end{array}$ \\
\hline $\begin{array}{l}\text { Corrugated steel culvert } \\
\text { Length: } 3.7 \mathrm{~m} \\
\text { Width: } 1.8 \mathrm{~m}\end{array}$ & $-235,-395$ & $\begin{array}{l}\text { Axis horizontal, oriented } \\
\text { north-south } / 2 \mathrm{~m} \text { to top }\end{array}$ & $\begin{array}{l}\text { GPR, TDEM, magnetic, } \\
\text { seismic, } R / I P \text {, and gravity }\end{array}$ \\
\hline $\begin{array}{l}\text { Reinforced concrete box } \\
\text { Length: } 2.3 \mathrm{~m} \\
\text { Width: } 2 \mathrm{~m} \\
\text { Height: } 1.75 \mathrm{~m}\end{array}$ & $-286,-453$ & $\begin{array}{l}\text { long axis horizontal, oriented } \\
\text { north-south/1.35 } \mathrm{m} \text { to top }\end{array}$ & $\begin{array}{l}\text { GPR, TDEM, magnetic, } \\
\text { seismic, and R/IP }\end{array}$ \\
\hline $\begin{array}{l}\text { Plastic tank: } \\
\text { Length: } 2.5 \mathrm{~m} \\
\text { Width: } 1.25 \mathrm{~m} \\
\text { Height: } 1 \mathrm{~m}\end{array}$ & $-374,-473$ & $\begin{array}{l}\text { Long axis horizontal, oriented } \\
\text { east-west/1 } \mathrm{m} \text { to top }\end{array}$ & $\begin{array}{l}\text { GPR, seismic, } R / / P \text {, and } \\
\text { gravity }\end{array}$ \\
\hline
\end{tabular}

airborne survey results show good agreement after consideration of the factors that control their individual responses.

\section{A. Surface Magnetics}

Surface magnetic surveys were conducted on a 4-m grid with an EDA Instruments OMNI-PLUS proton-precession magnetometer/gradiometer with a sensor height of $2 \mathrm{~m}$. Figure 5 is a map of the total

Table 2. RV GPER Site Background Characteristics

\begin{tabular}{|c|c|c|c|c|c|}
\hline \multirow{2}{*}{ Parameter } & \multicolumn{5}{|c|}{ Geophysical Survey Method } \\
\hline & $\begin{array}{c}\text { Airborne } \\
\text { Magnetic/EM }\end{array}$ & $\begin{array}{l}\text { Surface } \\
\text { Magnetic }\end{array}$ & $\begin{array}{l}\text { Surface } \\
\text { R/IP }\end{array}$ & $\begin{array}{l}\text { Surface } \\
\text { TDEM }\end{array}$ & $\begin{array}{l}\text { Surface } \\
\text { IEM }\end{array}$ \\
\hline Total Magnetic Field & $\begin{array}{l}53,456 \text { nanoteslas } \\
(\mathrm{nT}) \pm 9 \mathrm{nT}\end{array}$ & $53,467 \pm 4 n T$ & & & \\
\hline Vertical Magnetic Gradient & $0 \pm 0.25 \mathrm{nT} / \mathrm{m}$ & $-19 \pm 10 \mathrm{nT} / \mathrm{m}$ & & & \\
\hline $\begin{array}{l}\text { Near-Surface Apparent } \\
\text { Resistivity }\end{array}$ & $\begin{array}{l}25 \text { ohm-meters } \\
(\Omega-m)\end{array}$ & & $50 \Omega-m$ & $5 \Omega-m$ & \\
\hline Deep Apparent Resistivity & $7 \Omega-m$ & & $10-20 \Omega-m$ & $5 \Omega-m$ & \\
\hline Near-Surface Conductivity & & & & & $\begin{array}{l}40 \pm 10.2 \text { millisiemens } \\
\text { per meter }\end{array}$ \\
\hline Near-Surface In-Phase & & & & & $\begin{array}{l}1 \pm 0.2 \text { parts per } \\
\text { thousand }\end{array}$ \\
\hline
\end{tabular}




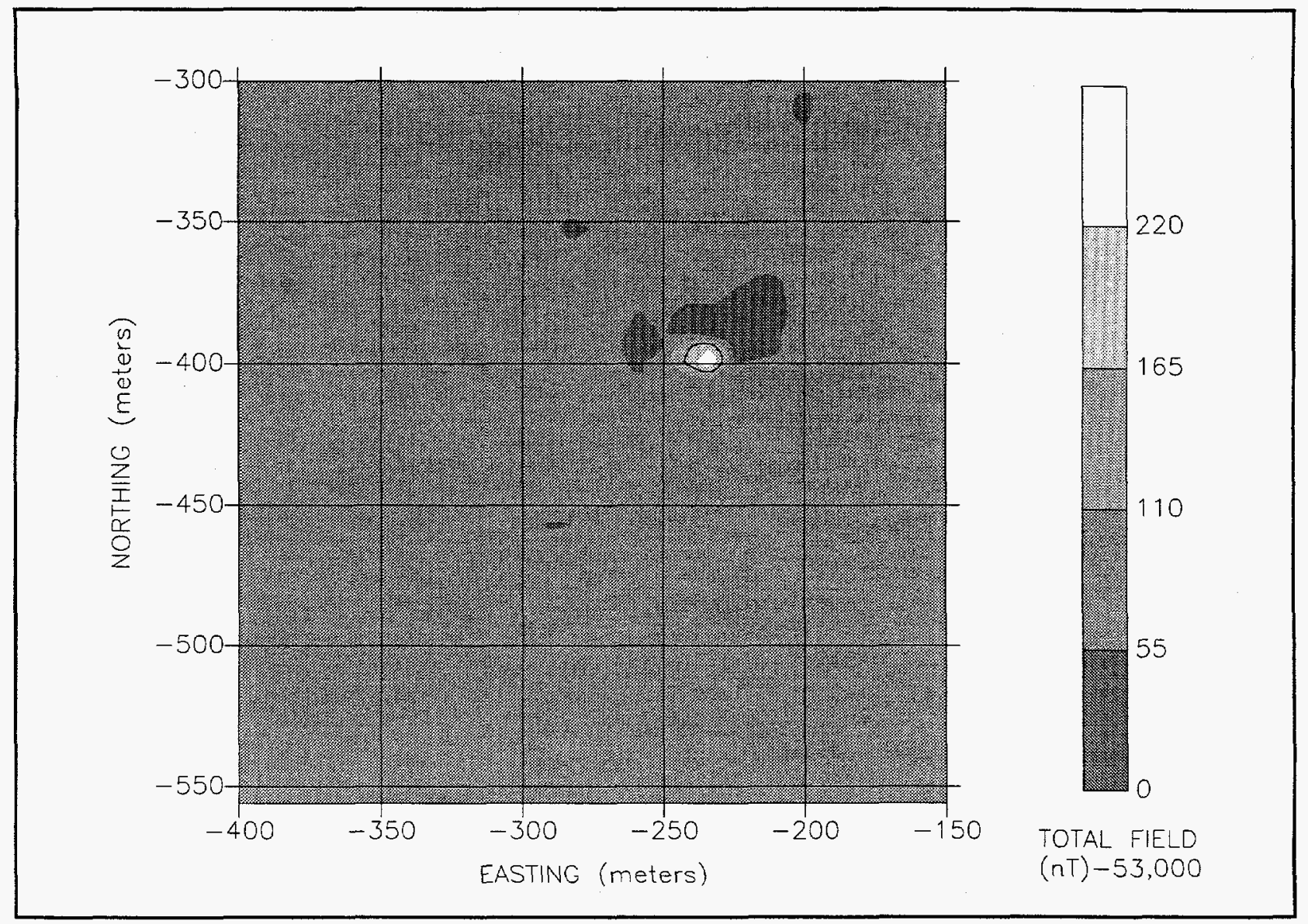

Figure 5. Total Magnetic Field at Surface

field, while Figure 6 shows the vertical gradient. The average total field was $53,477 \pm 4$ nanoteslas (nT) with a mean vertical gradient of $-19 \pm 10$ nanoteslas per meter $(\mathrm{nT} / \mathrm{m})$ over the site. Total field and vertical gradient anomalies were apparent over the magnetic targets previously buried at the site.

\section{B. Airborne Magnetics}

Airborne magnetic surveys were conducted along east-west flight lines spaced $16 \mathrm{~m}$ apart. The surveys were conducted by a subcontractor, High-Sense Geophysics Ltd., with a Picodas PDAS-1000 magnetometer coupled to a Scintrex H8 cesium-vapor sensor. The sensor was flown in a "bird" suspended $24.4 \mathrm{~m}$ below a Bell Long Ranger 3 helicopter. Sensor altitude was nominally $30 \mathrm{~m}$ above the terrain. Survey results indicate an average total field of $53,456 \pm 9 \mathrm{nT}$, as shown in Figure 7 . This value is readily reconciled with the value recorded on the surface. Identifiable total field anomalies were recorded over the large steel culvert previously buried at the site. Responses from the small steel culvert and the steel-reinforced concrete tank were not as prominent.

\section{Induction Electromagnetic}

IEM surveys were performed on a 4-m grid with a Geonics EM-31 ground conductivity meter.

Measurements were conducted using the vertical magnetic dipole (VMD) mode with the boom oriented parallel to the survey lines. Figures 8 and 9 show the conductivity and in-phase components, respectively. Near-surface conductivity ranged from 20 to 70 millisiemens per meter $(\mathrm{mS} / \mathrm{m})$, with an average value of $40 \pm 0 \mathrm{mS} / \mathrm{m}$. Conductivity values reflect some rather large lithologic features centered 


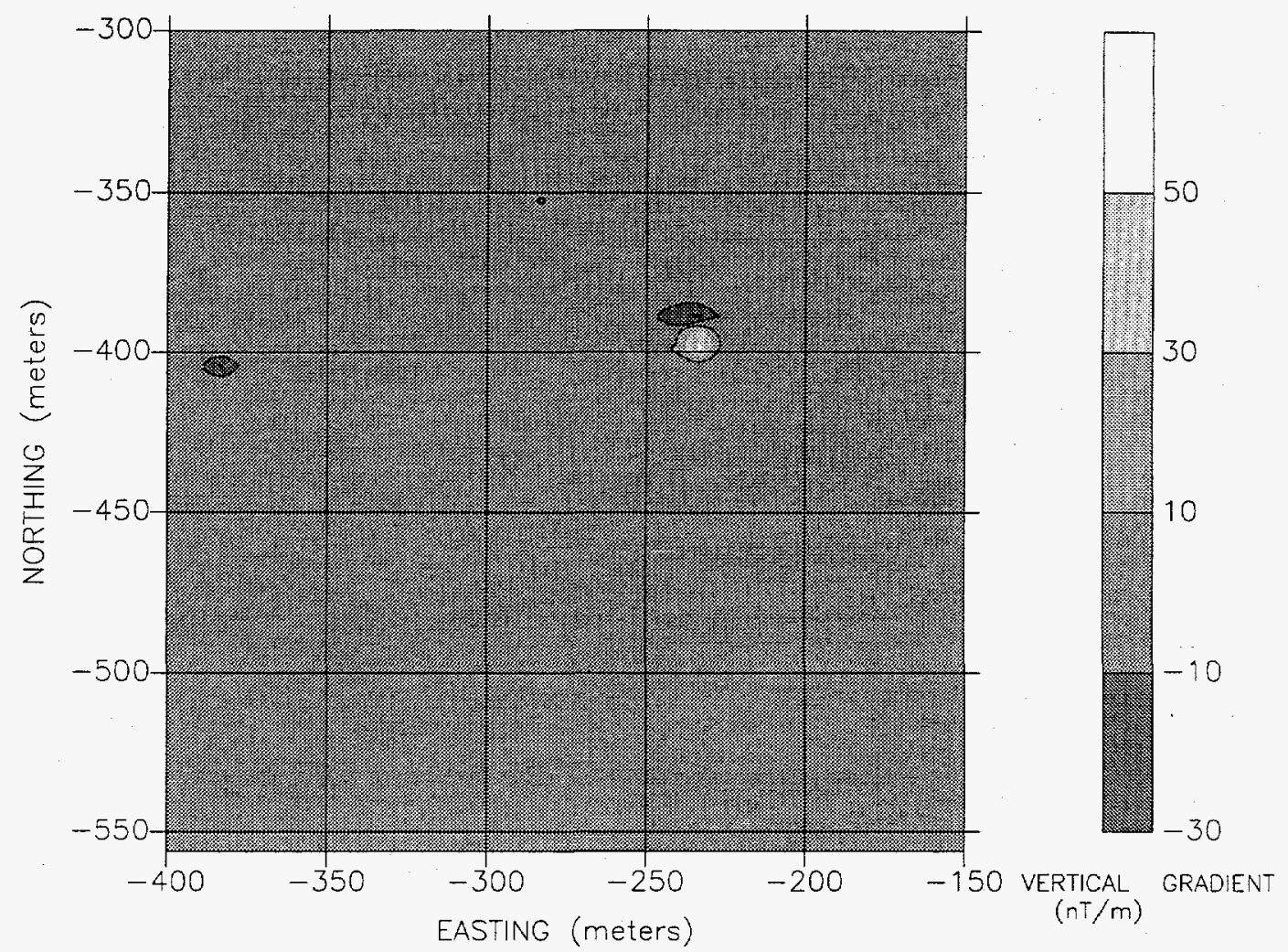

Figure 6. Vertical Gradient of Magnetic Field at Surface

around $(-320,-460)$ and $(-200,-480)$. The in-phase component ranged from -1.8 to +8 parts per thousand (ppt) with an average value of $0.5 \mathrm{ppt}$. Note the prominent anomalies over the large steel culvert at $(-235,-395)$ and the steel reinforced concrete box at $(-286,-453)$. Figure 10 is an expanded-scale contour plot of the in-phase anomaly over the large steel culvert. The smaller steel culvert did not produce a readily discernible in-phase anomaly as expected.

\section{Very Low Frequency Electromagnetic}

VLF-EM data were recorded on a 4-m grid with an EDA OMNI-PLUS magnetometer/VLF system concurrently with the surface magnetic surveys. Although field strengths were adequate from the three VLF transmitters recorded (Cutler, Maine, 24.0 kilohertz [kHz]; Annapolis, Maryland, $21.4 \mathrm{kHz}$; and Jim Creek, Washington, $24.8 \mathrm{kHz}$ ), the background data were generally uninteresting. Figure 11 is typical of the results obtained using signals from NSS, Annapolis, Maryland, at $21.4 \mathrm{kHz}$.

\section{E. Time-Domain Electromagnetic}

TDEM surveys were conducted on a 4-m grid with a Geonics TEM-47 system and a GJPO-developed rigid transmitter loop. The rigid transmitter loop provided a constant moment of 100 ampere turns meters squared $\left(\mathrm{Atm}^{2}\right)$ and was easily moved from station to station. Transmitter-antenna-to-receiverantenna spacing was maintained at $10 \mathrm{~m}$, edge-to-edge. Figures 12,13, and 14 show apparent resistivity at early, medium, and late times, respectively. 


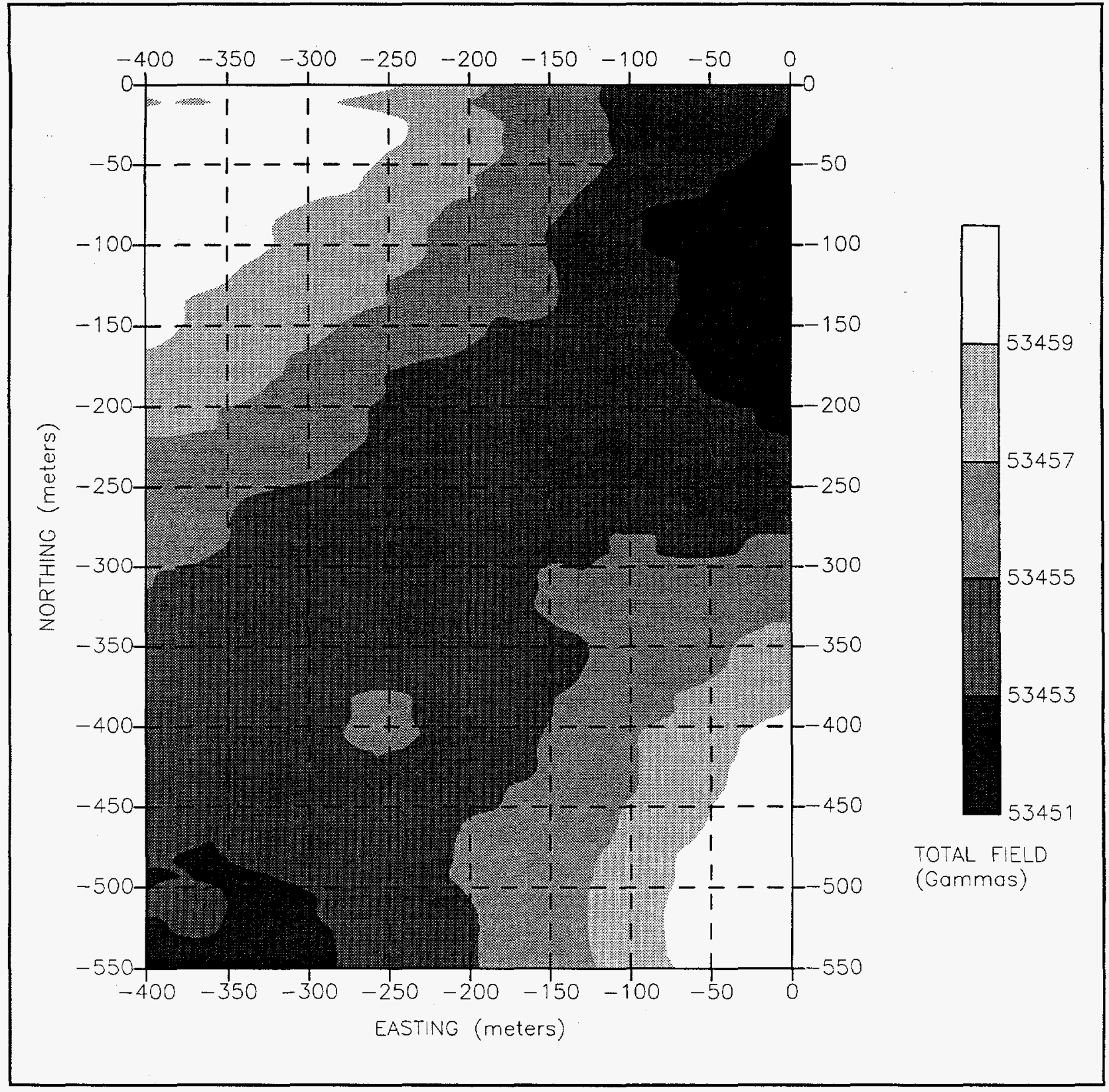

Figure 7. Total Magnetic Field at 50 Meters Above Surface 


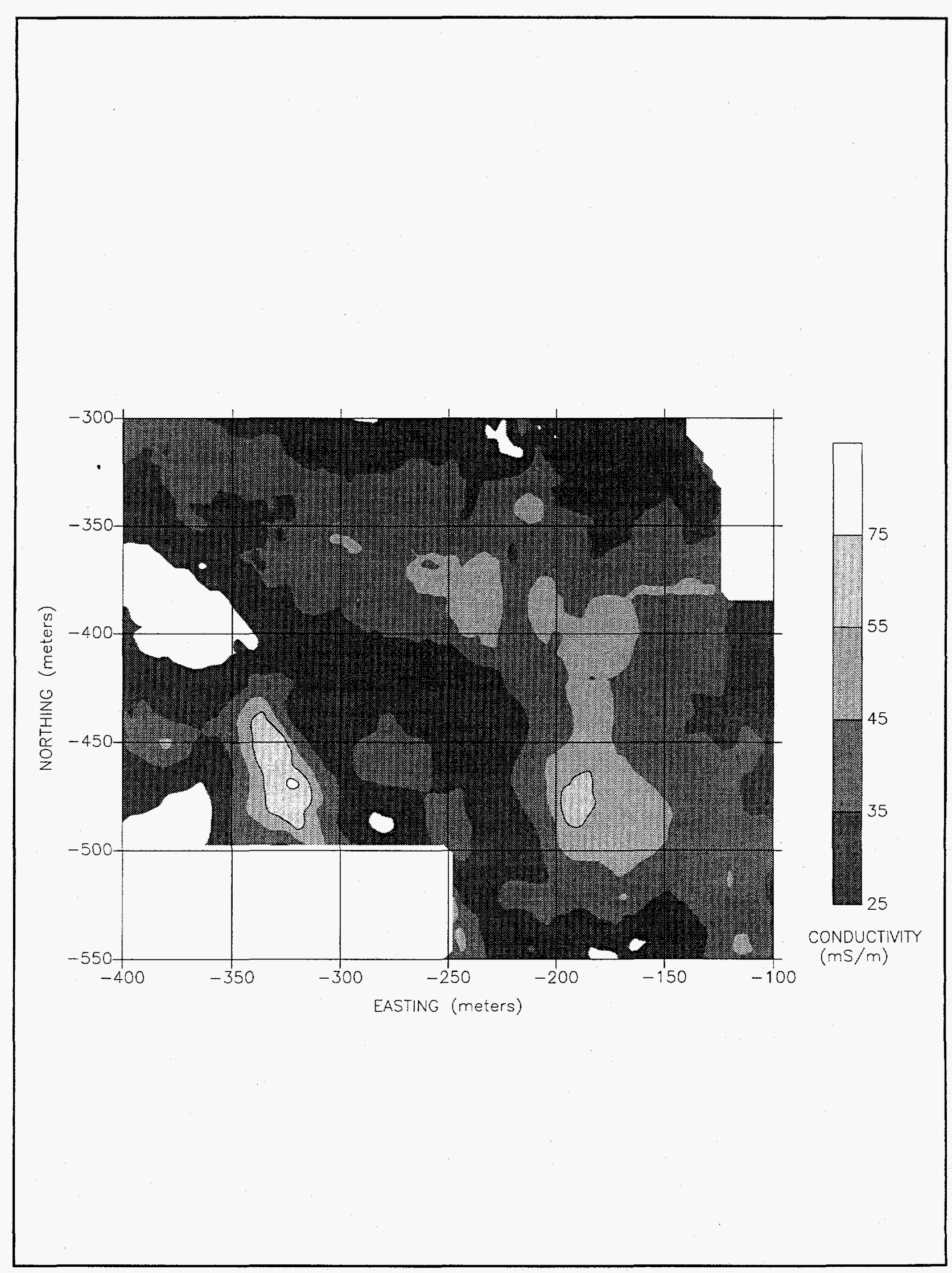

Figure 8. Conductivity From EM-31 Survey 


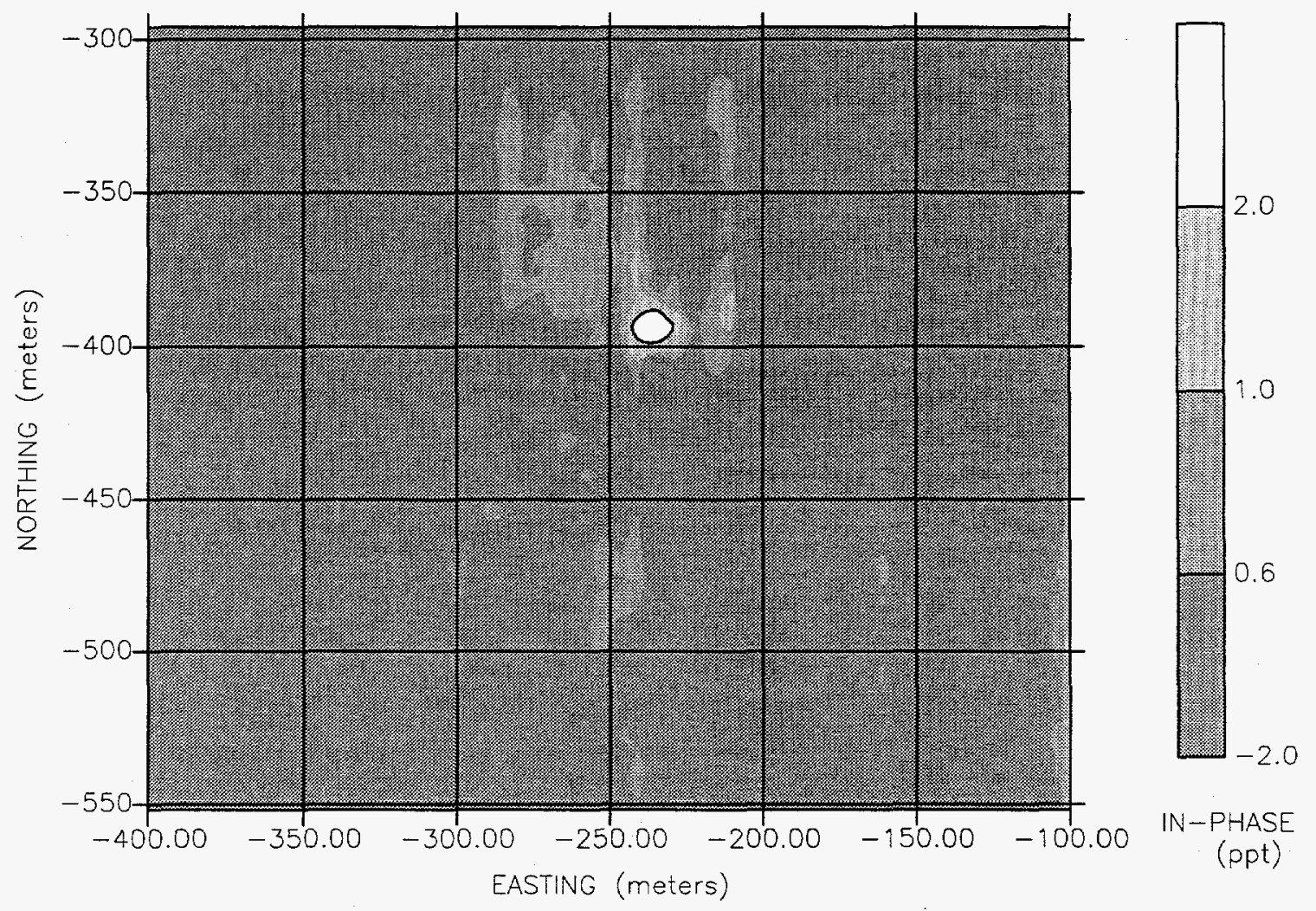

Figure 9. In-Phase From EM-31 Survey

\section{F. Airborne Electromagnetic}

Airborne electromagnetic (AEM) surveys were conducted by a subcontractor, High-Sense Geophysics Ltd., with a four-frequency EM system consisting of two coaxial coil pairs operating at 919 and 4355 hertz $(\mathrm{Hz})$ and two coplanar coil pairs operating at 4165 and $35600 \mathrm{~Hz}$. The coils were housed in a bird suspended $3 \mathrm{~m}$ below a Bell Long Ranger 3 helicopter. The system simultaneously recorded in-phase and quadrature components for the four frequencies at a rate of 10 times per second.

Figures 15 and 16 show the resulting apparent resistivity for the coplanar coils operating at 4165 and $35.6 \mathrm{kHz}$, respectively.

\section{G. Resistivity/Induced Polarization}

$\mathrm{R} / \mathrm{IP}$ surveys were conducted on a 4-m grid with an Androtex TDR-6 receiver and a Phoenix IPT-1 transmitter. A gradient-array configuration was employed with the survey lines running east-west with porous-pot receiver electrodes spaced $4 \mathrm{~m}$ apart. Transmitter electrodes were placed $300 \mathrm{~m}$ on either side of each $25-\mathrm{m}$ survey block. Figures 17 and 18 show the apparent resistivity and the induced polarization, respectively. 


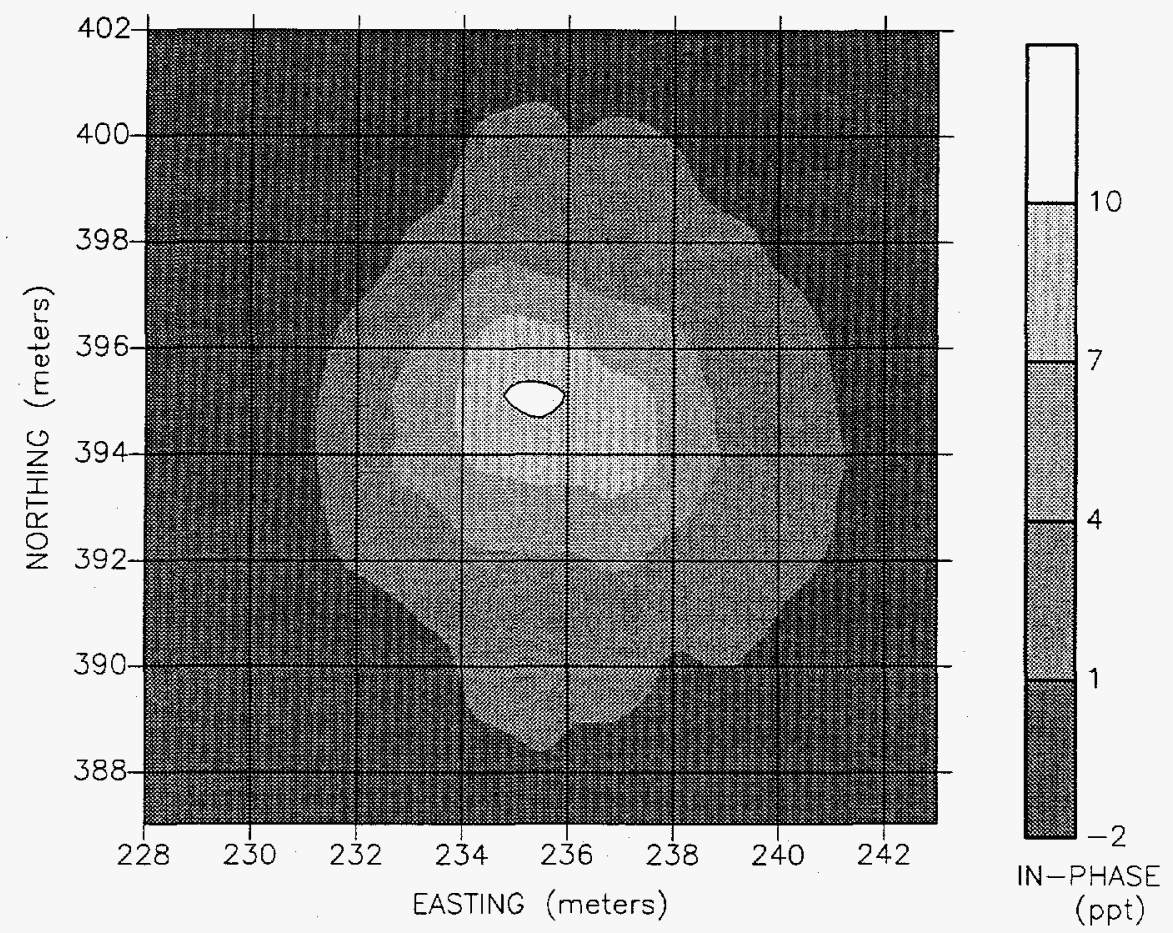

Figure 10. In-Phase Anomaly Over Large Steel Culvert

\section{H. Ground-Penetrating Radar}

GPR surveys were conducted over some of the previously buried targets and a 30-m-long east-west line (440 South) in the area where the Sand Pit (Area 4) was later constructed. A GSSI SIR-8 impulse-type radar was used in these surveys. The east-west line in Area 4 surveyed with the 80 megahertz $(\mathrm{MHz})$ antenna showed only three or four small reflections (see Figure 19) in the near-surface that were attributed to lithologic variations. Penetration was estimated to be $1 \mathrm{~m}$. Surveys over the concrete septic tank and the large steel culvert produced no recognizable signatures. Previous surveys over an empty concrete vault (Allen 1990) and a polyvinyl chloride (PVC) pipe cache (Allen 1992) in the northern area had produced excellent signatures at 300 and $500 \mathrm{MHz}$, respectively. Figures 21 and 22 show the results of 500-MHz surveys over the empty concrete vault and the PVC pipe cache, respectively. The results obtained by DOE Special Technologies Laboratory personnel (Koppenjan and Martinez 1994) were similar; they obtained good signatures over the empty concrete vault but were unable to "see" the steel culvert and concrete septic tank. Coleman Research Corporation obtained somewhat better results, producing good images over the empty concrete cylinder and the plastic cylinder and marginal images over the steel culvert and concrete septic tank. The higher clay content in the soils surrounding the steel culverts and the concrete septic tank may contribute to the poorer performance in this area. Soil samples collected during the earlier surveys over the empty concrete cylinder and the PVC pipe cache showed only 1.9-percent clay fraction compared to the 6 to 10 percent in the samples collected during construction. 


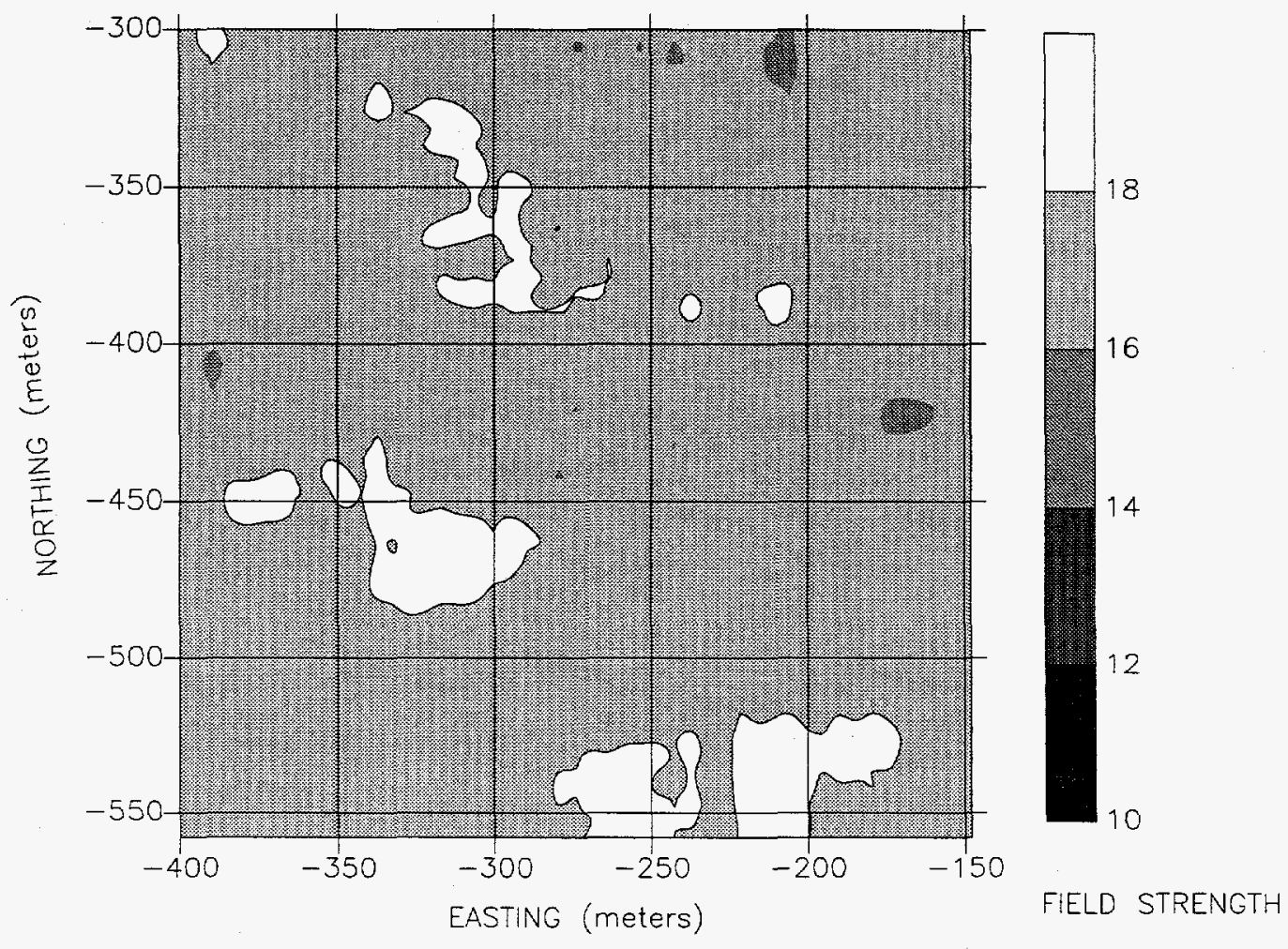

Figure 11. Field Strength of 21.4-kHz VLF-EM

\section{Range Construction and Soil Sample Analysis}

Construction of the Rabbit Valley GPER test cells began in Area B on April 23, 1994, and was completed on May 12, 1994. Construction was performed by Sorter Construction Company of Grand Junction, Colorado, under a subcontract. All construction activities were conducted in accordance with the Rabbit Valley Geophysics Performance Evaluation Range (GPER) Health and Safety Plan (Geotech 1994b); Minimum Drilling Health and Safety Requirements for Operation of Small Auger, Rotary, and Core Rigs (Geotech 1994a); Rabbit Valley Geophysics Performance Evaluation Range (GPER) Health and Safety Plan (Sorter 1994b); Safety Management Plan (Sorter 1994c); and a site-specific Health and Safety Attachment 1-12-94 (Sorter 1994a). Geotech personnel conducted a site safety briefing for all on-site participants before the start of construction. The Sorter foreman conducted daily "tailgate" safety briefings. A Geotech health and safety technician conducted daily inspections of construction activities, and a Geotech Construction health and safety engineer performed periodic inspections of Sorter's heavy equipment and tools.

A Geotech construction inspector monitored all construction activities, authorized departures from the cell specifications (i.e., depth of targets, clay layer thickness), and recorded as-built specifications for target locations, orientations, and depths. The construction inspector made photographic records (still and video) of construction activities and progress. Figures 22 through 32 show various stages in the construction, including target placement details. Figure 22 presents excavation in progress for the Clay Pit (Area 5); note the stepped vertical boundary at the left edge of the pit. Figure 23 shows the large excavator during excavation of the Sand Pit (Area 4); note the dust near the bucket of the excavator. 

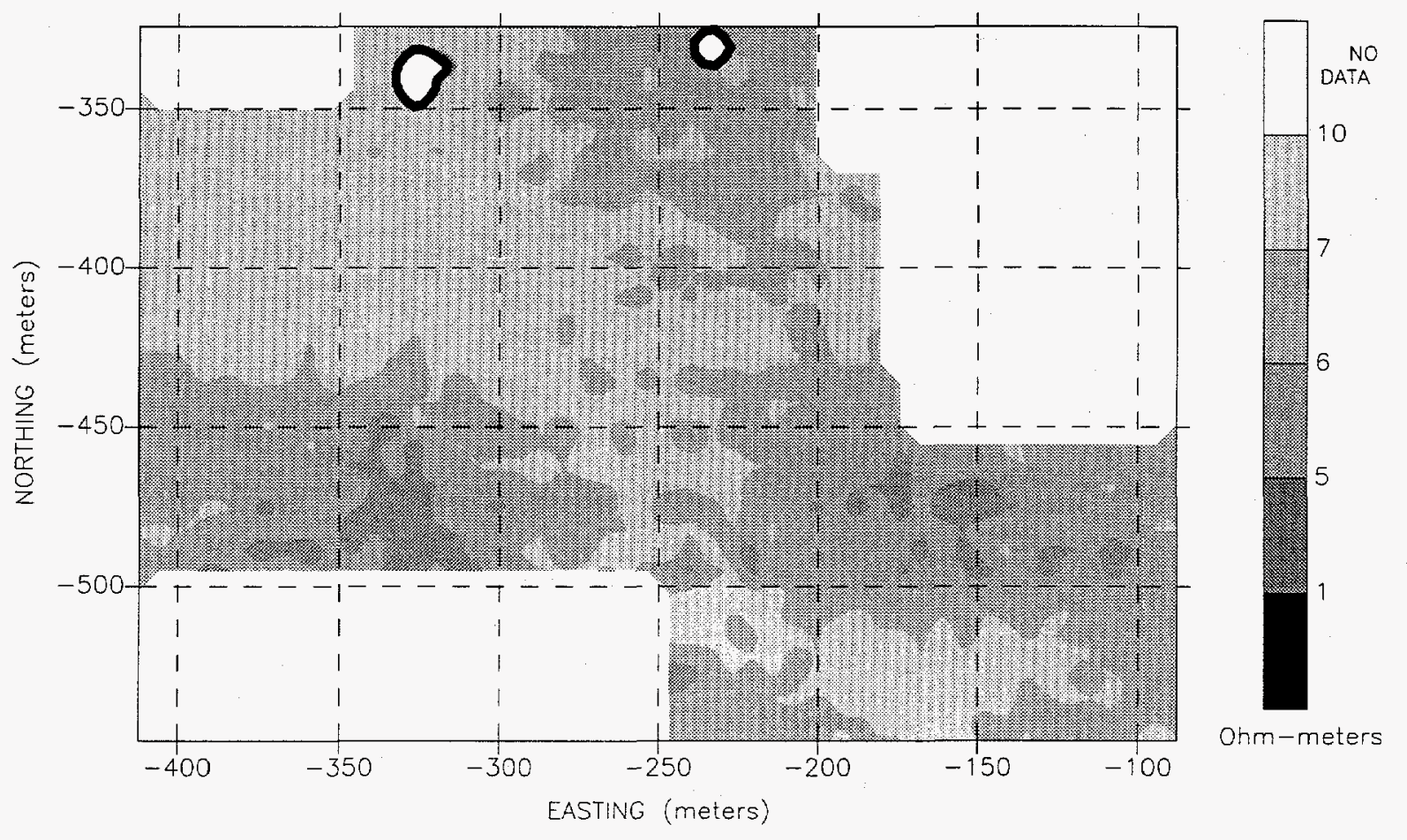

Figure 12. Apparent Early-Time Conductivity From TDEM Survey Before Construction 


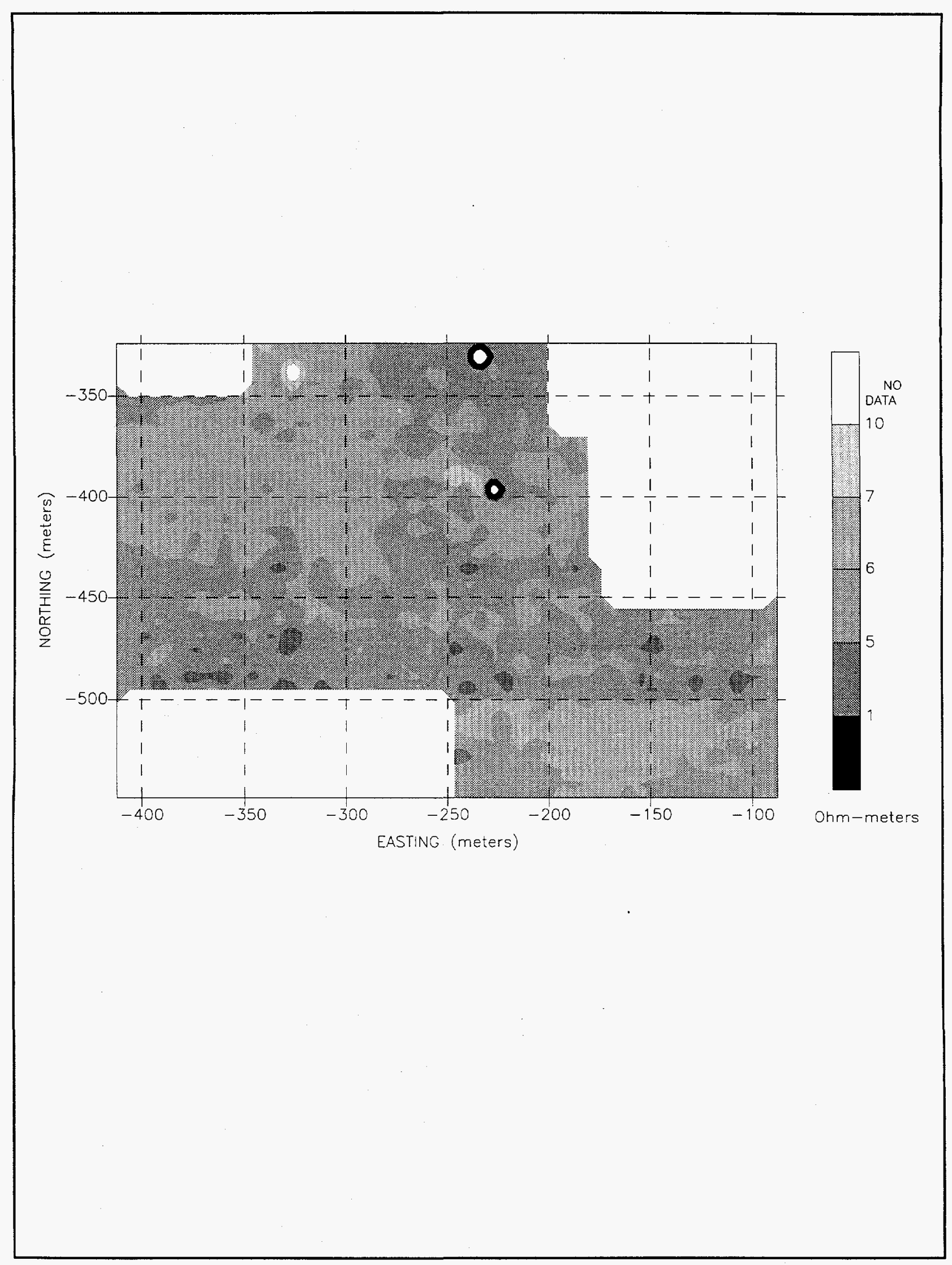

Figure 13. Apparent Medium-Time Conductivity From TDEM Survey 


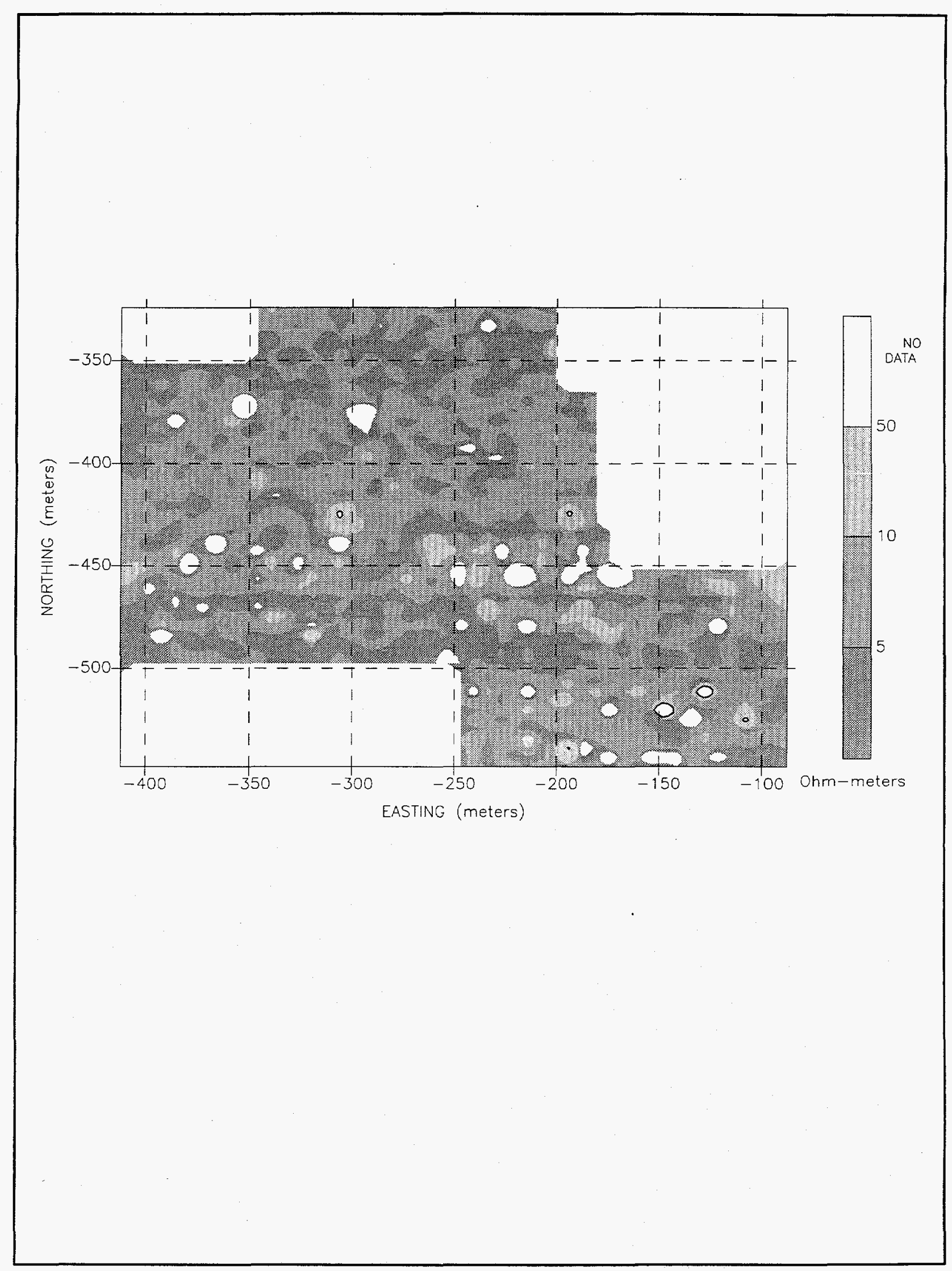

Figure 14. Apparent Late-Time Conductivity From TDEM Survey 


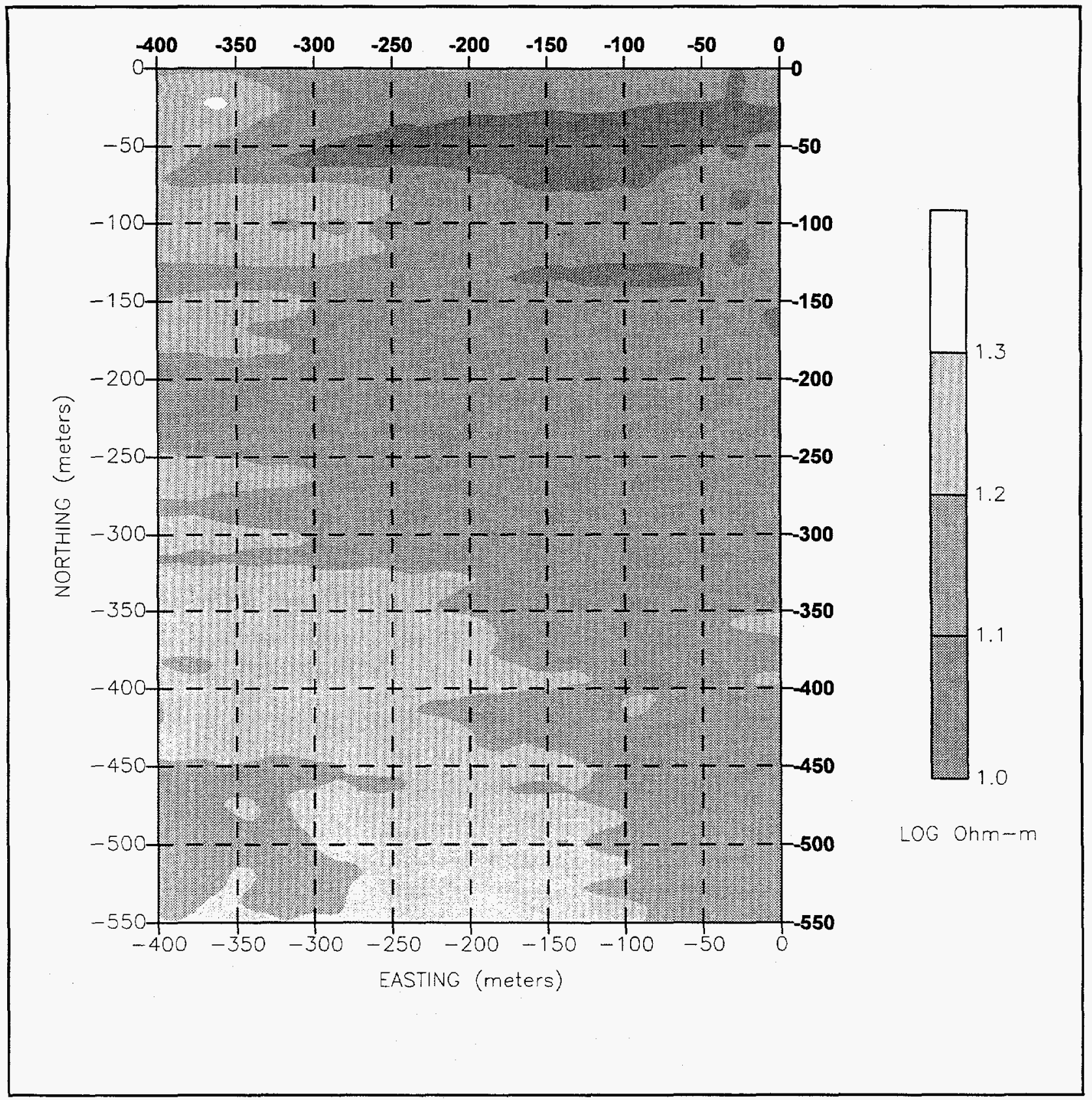

Figure 15. Apparent Resistivity at $4165 \mathrm{~Hz}$ From Airborne EM Survey 


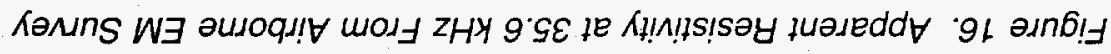

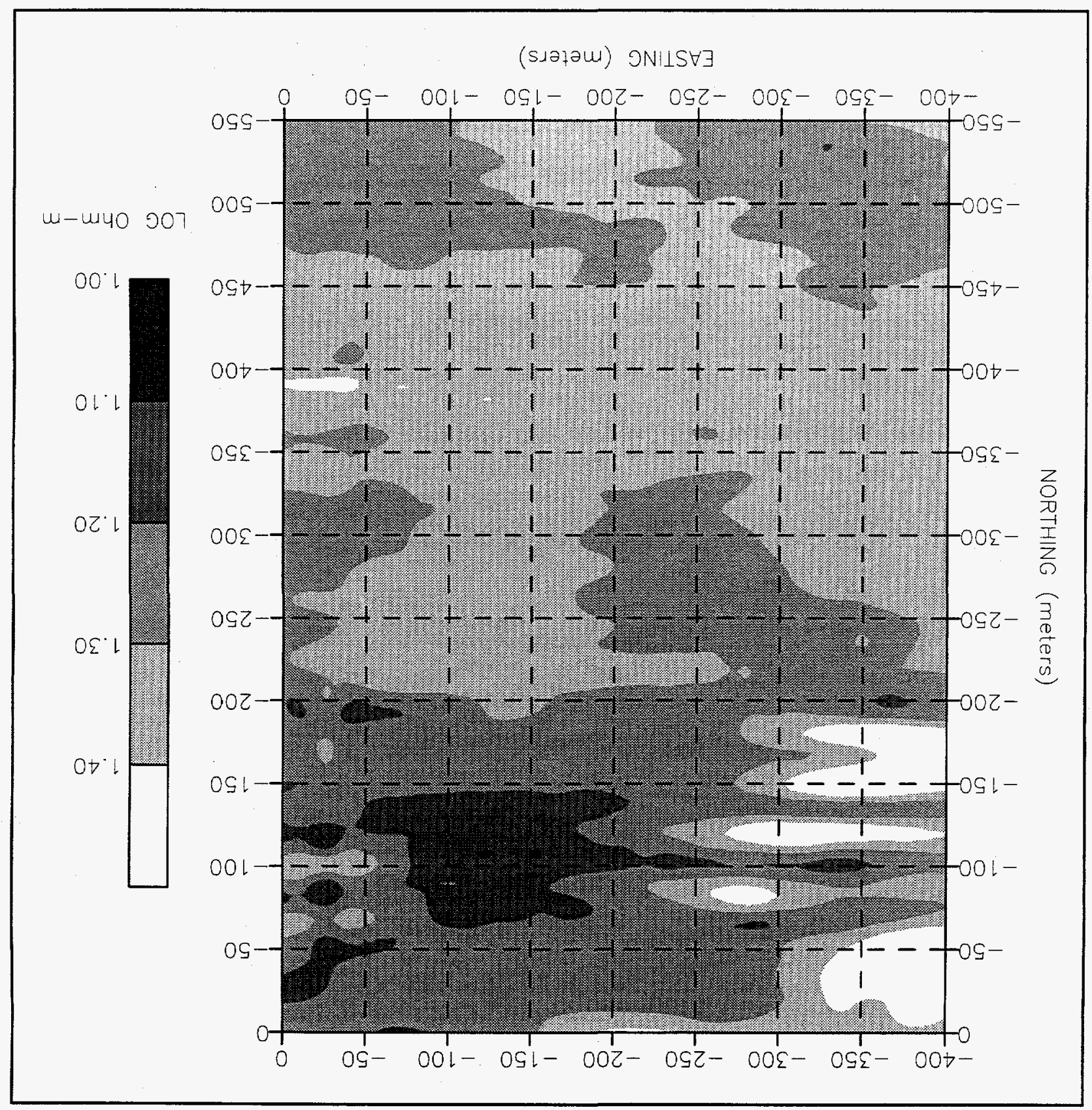




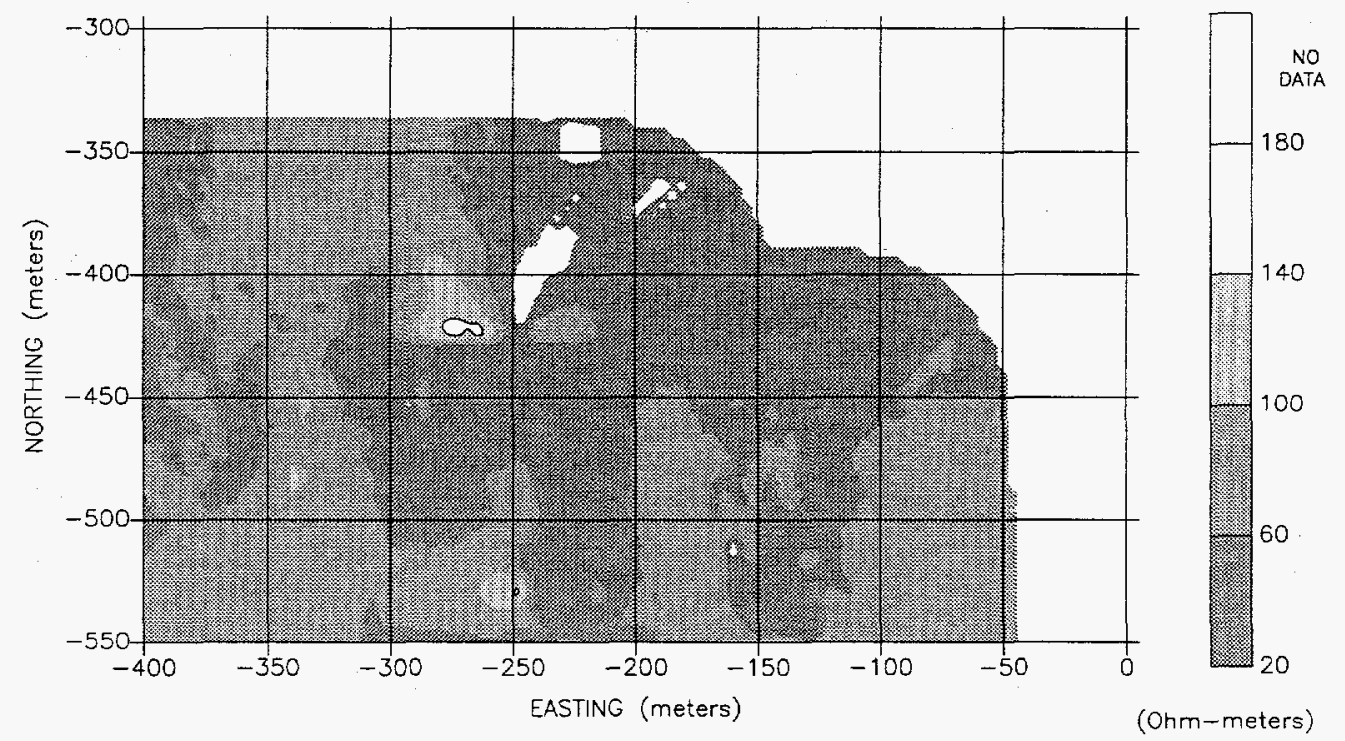

Figure 17. Apparent Resistivity From Surface R/IP Survey
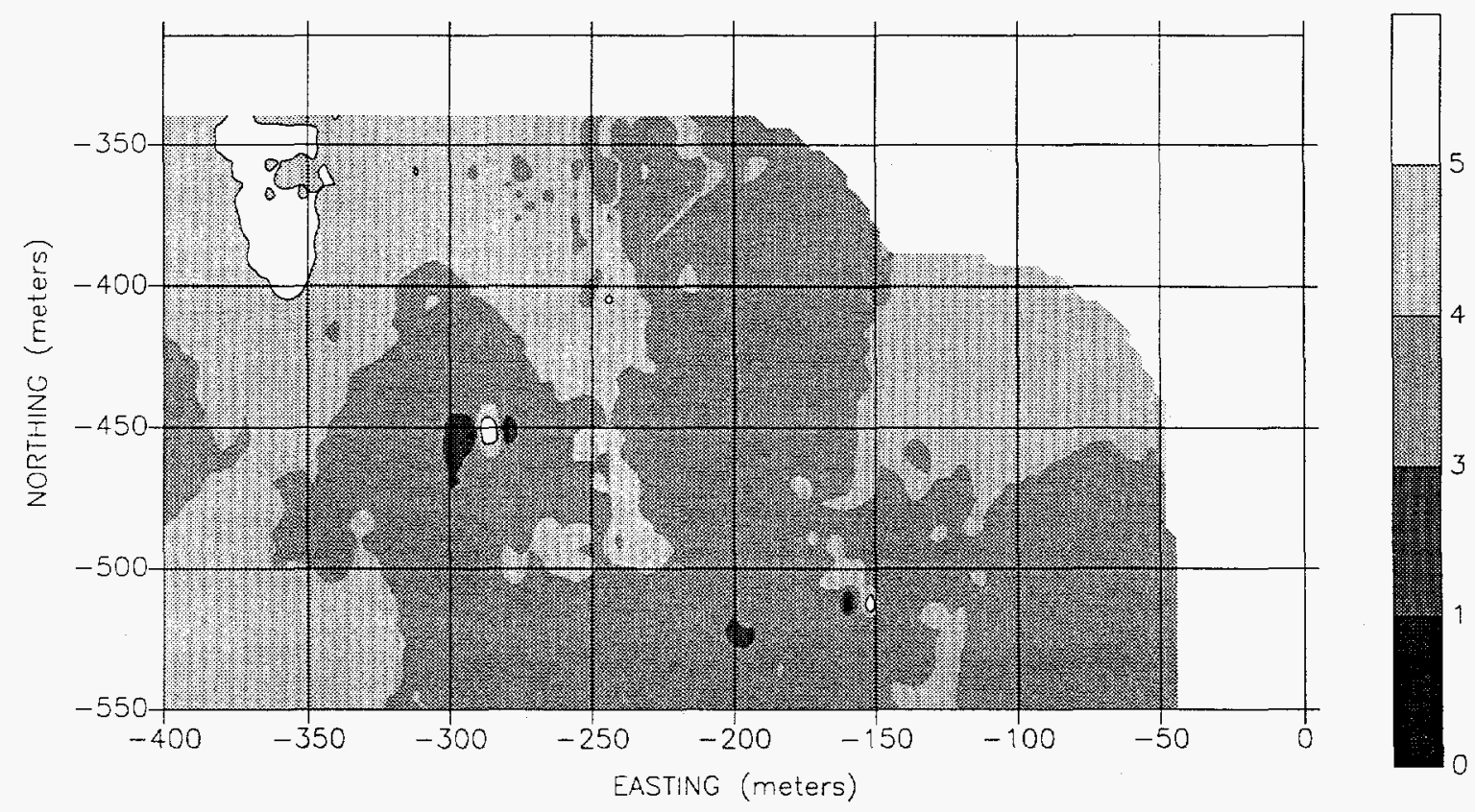

IP EFFECT

$\mathrm{mV} / \mathrm{VmS}$

Figure 18. Induced Polarization From Surface R/IP Survey 


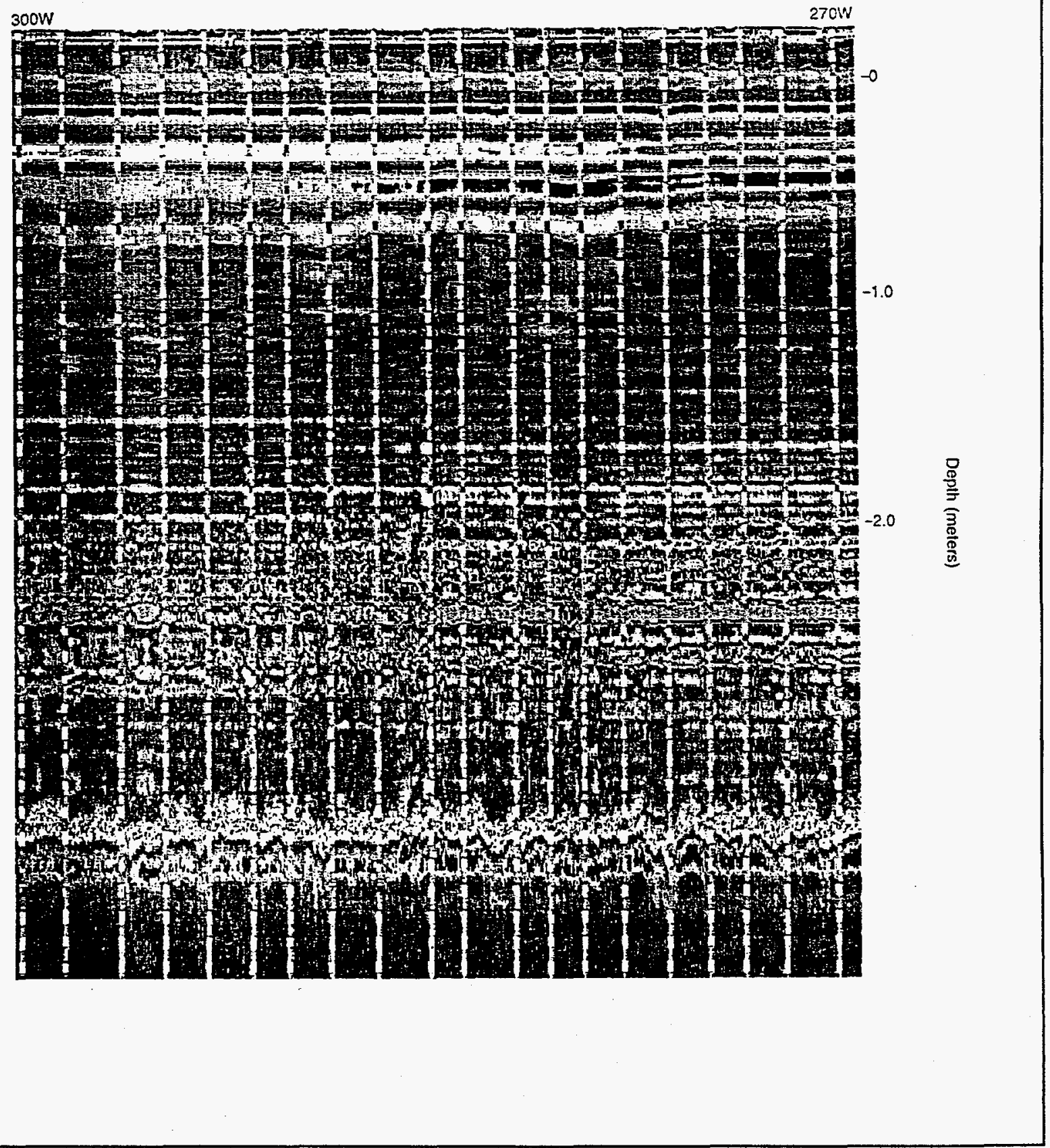

Figure 19. GPR Survey at $80 \mathrm{MHz}$ Along Line $440 \mathrm{~S}$ 

Distance (meters)

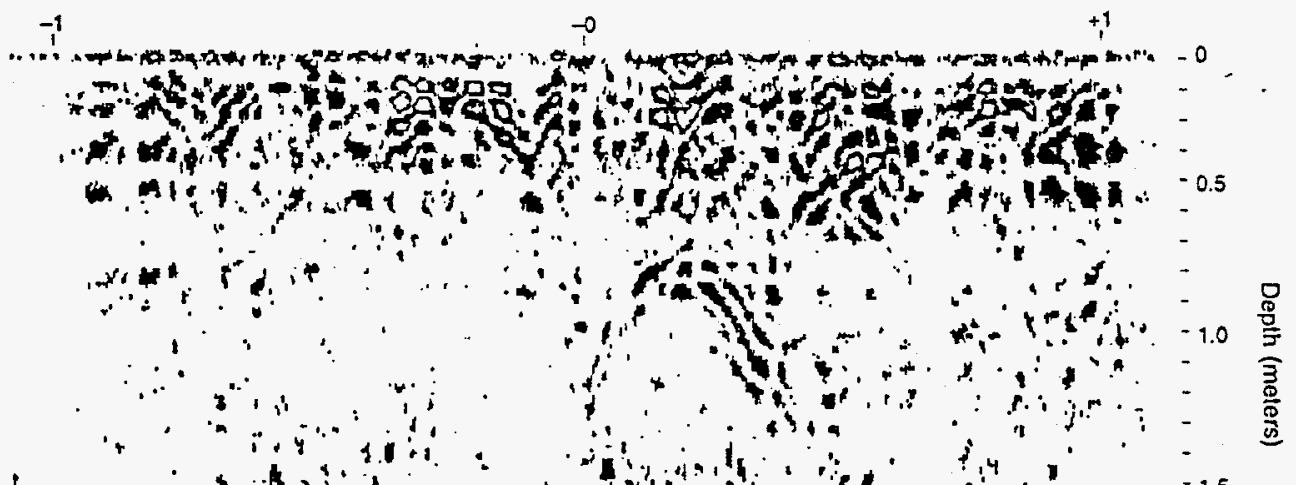

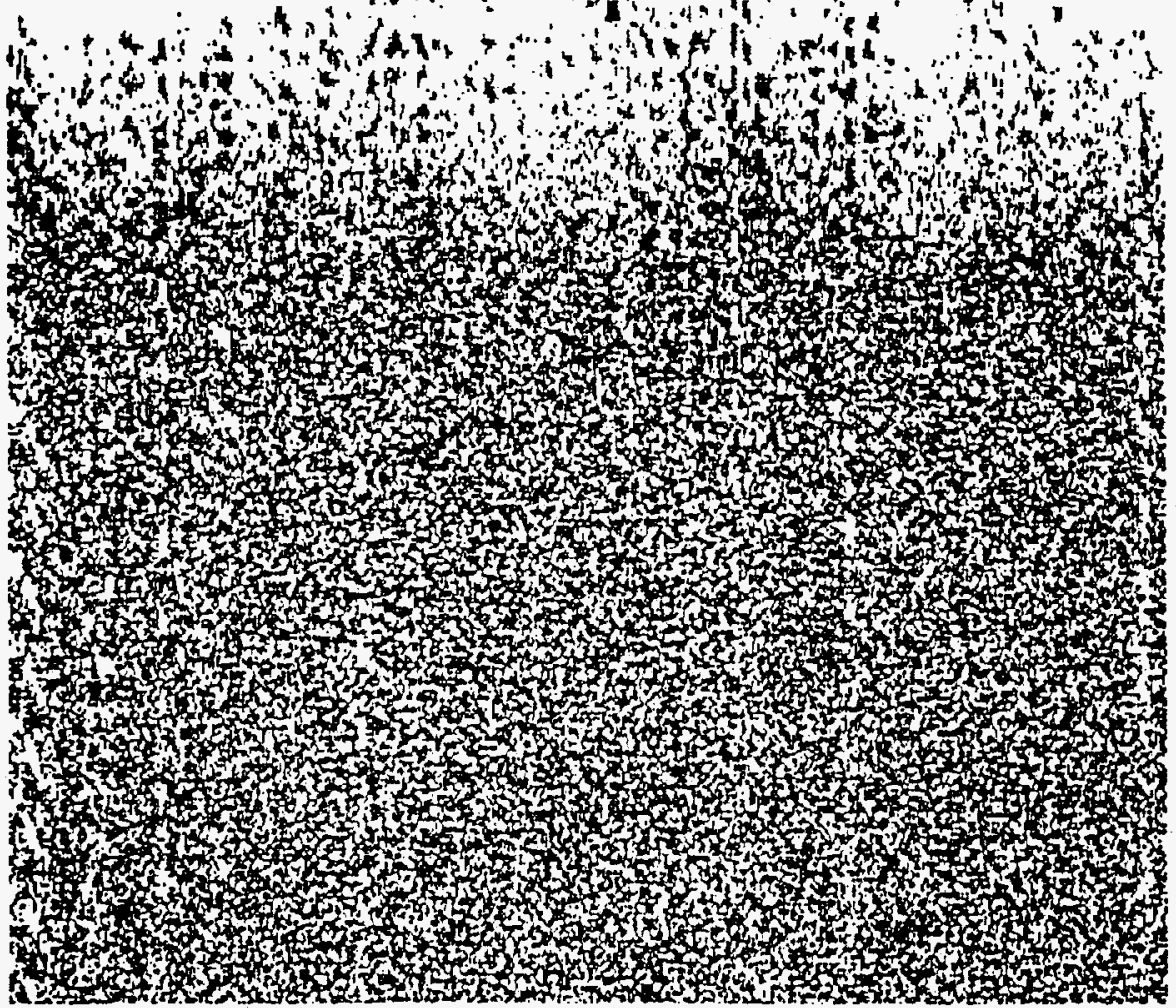




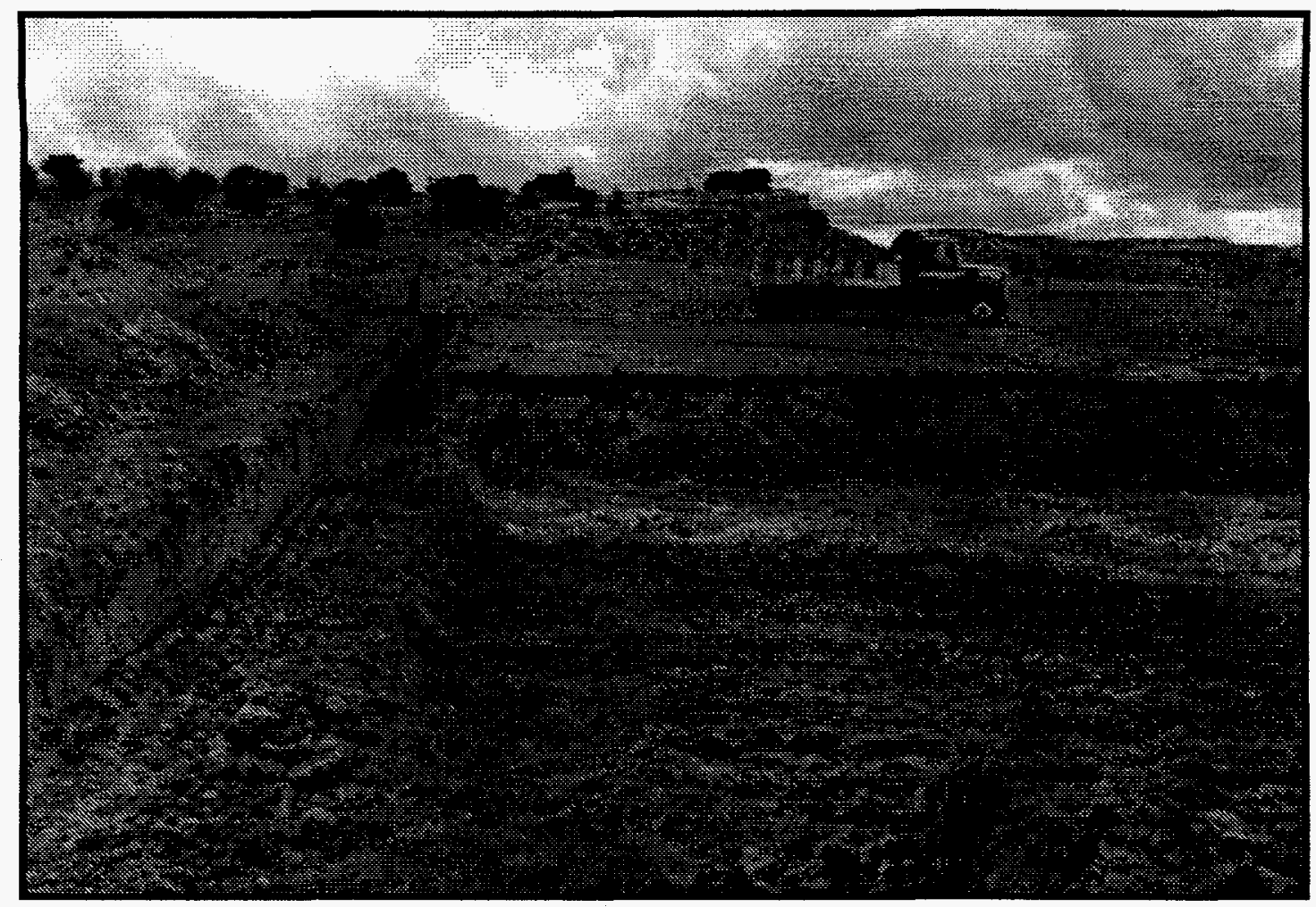

Figure 22. Construction of Clay Pit (Area 5) Showing Pit Boundary

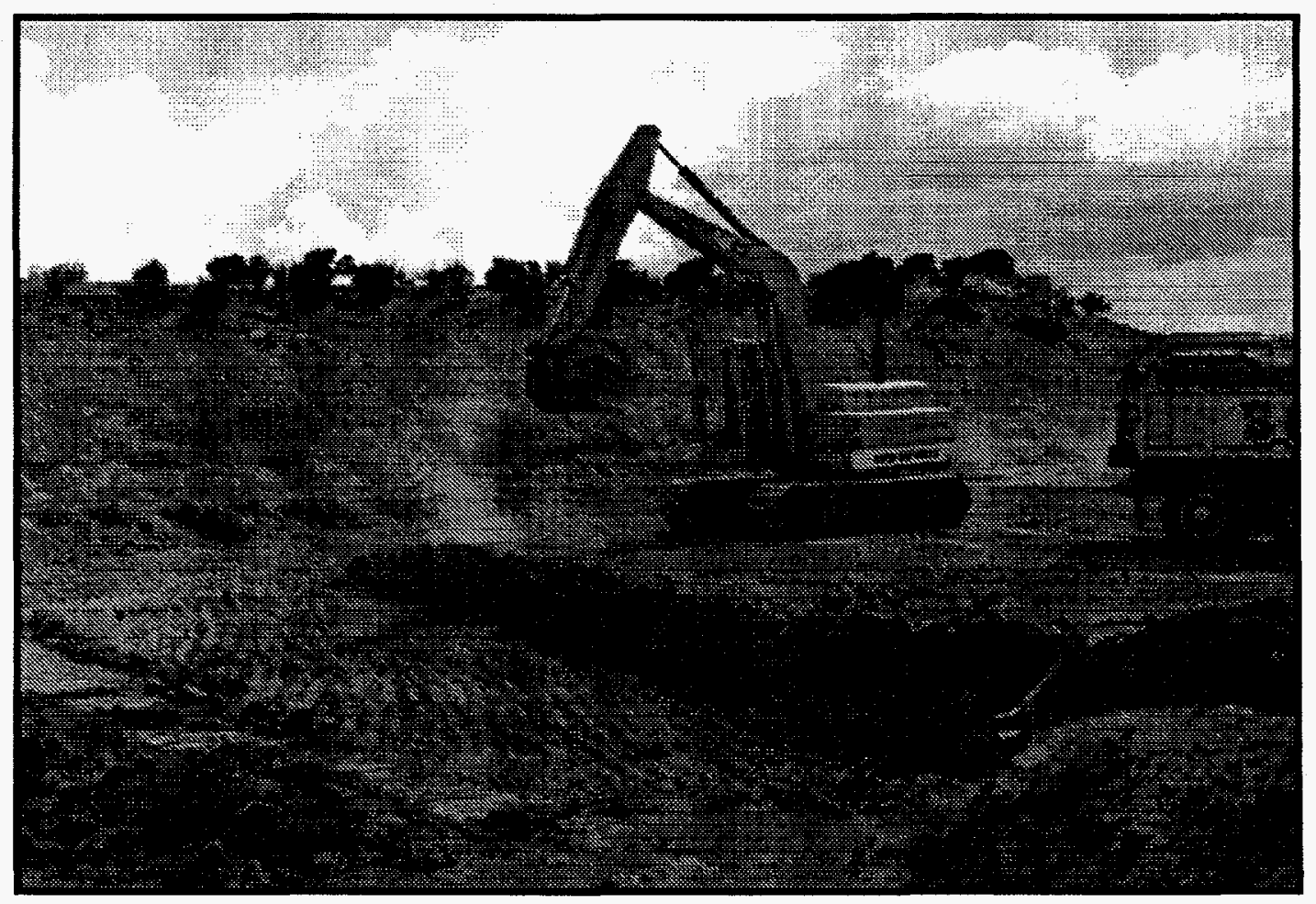

Figure 23. Construction of Sand Pit (Area 4) Showing Excavator in Action 


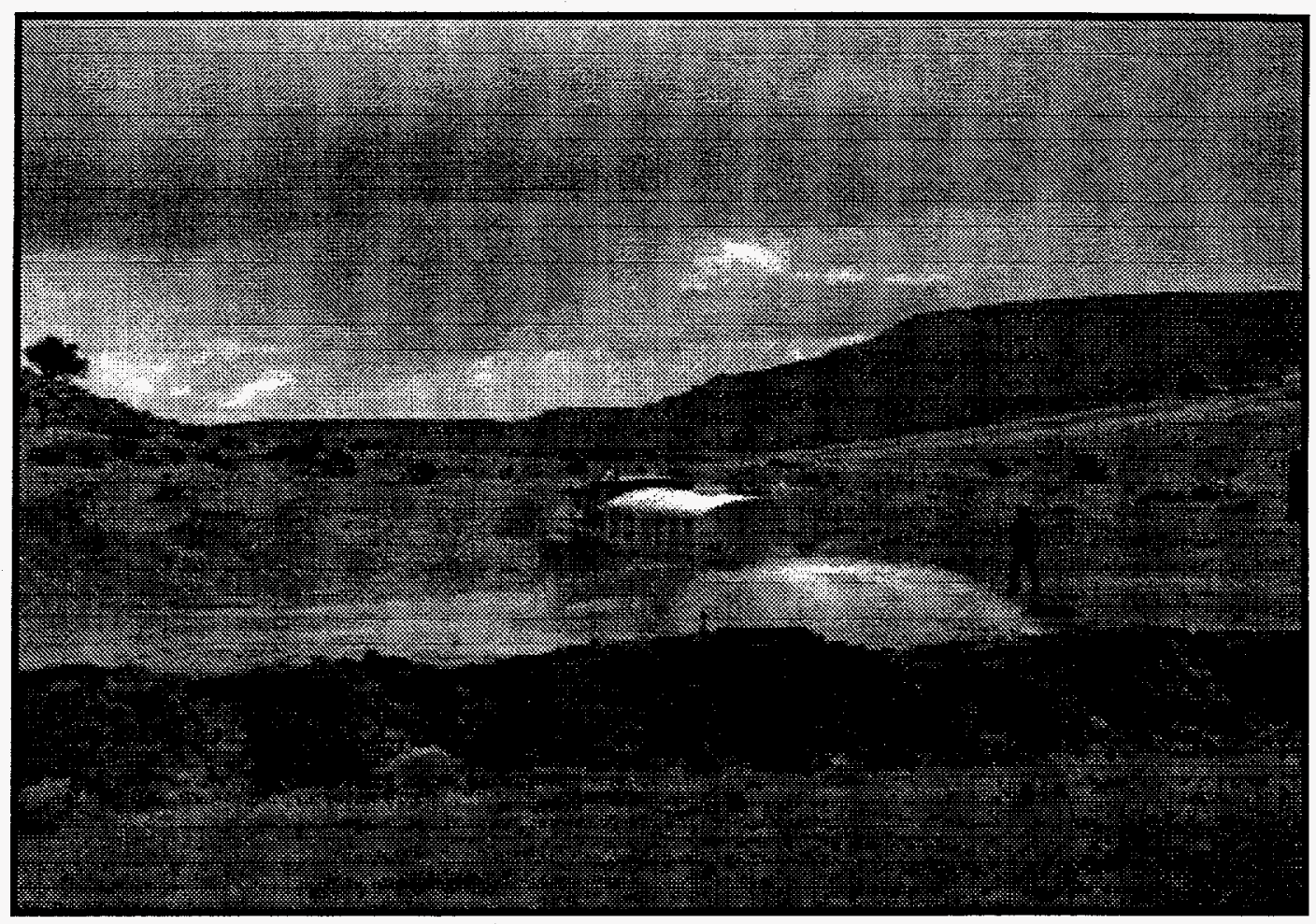

Figure 24. Dust Control in Action at Sand Pit

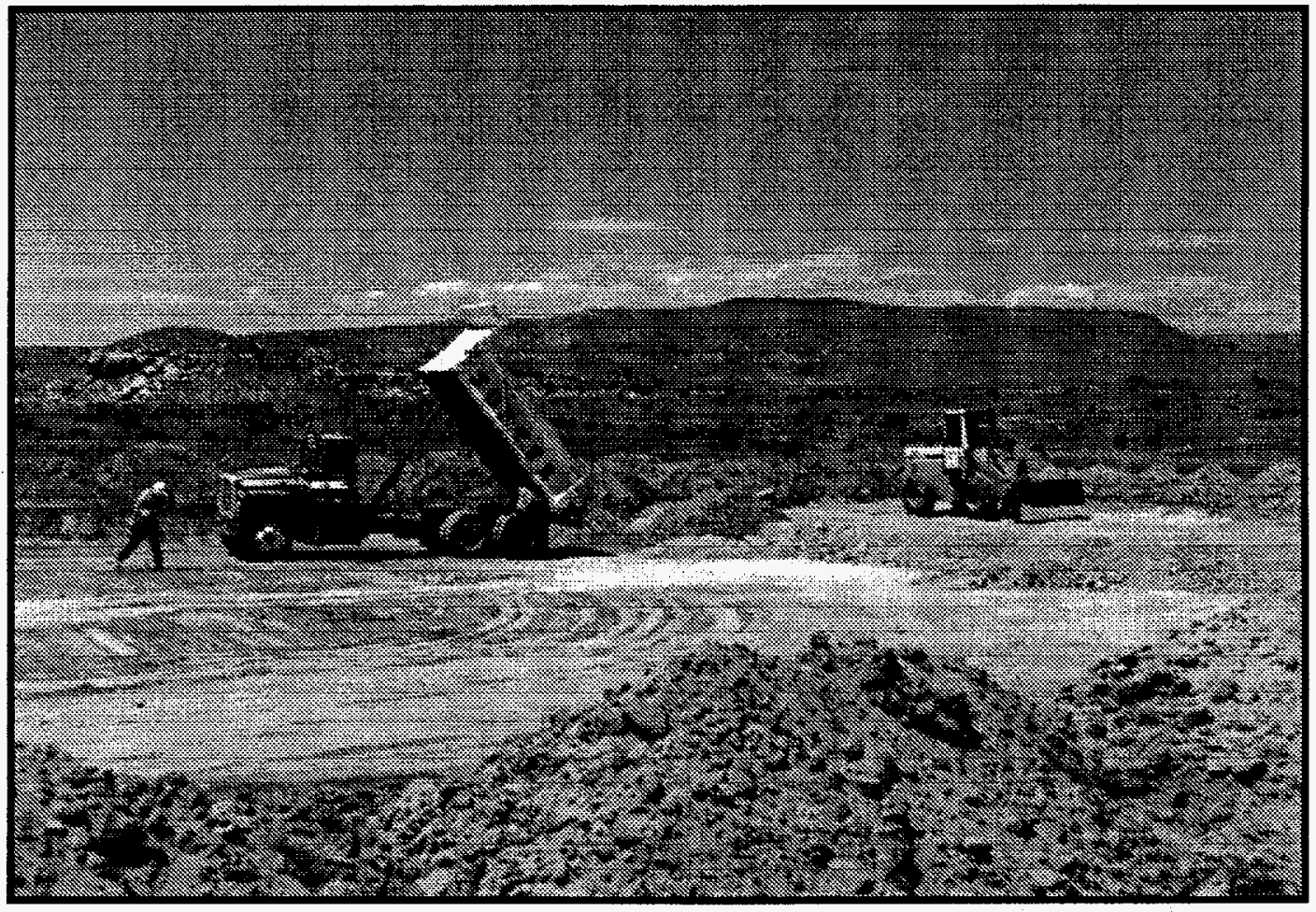

Figure 25. Placement of Clay Layer in Clay Pit 

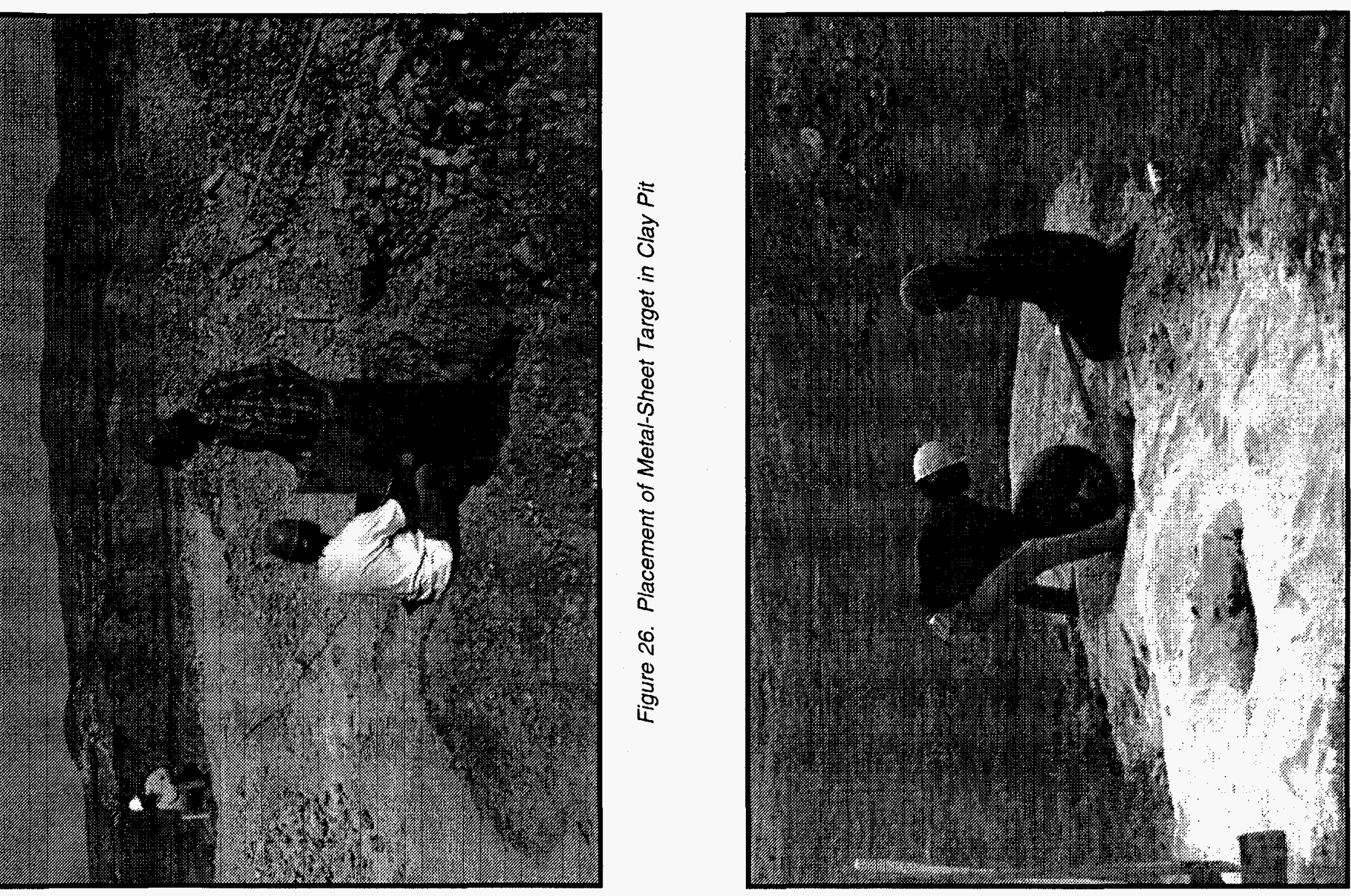

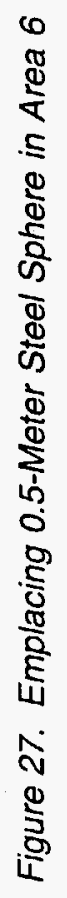




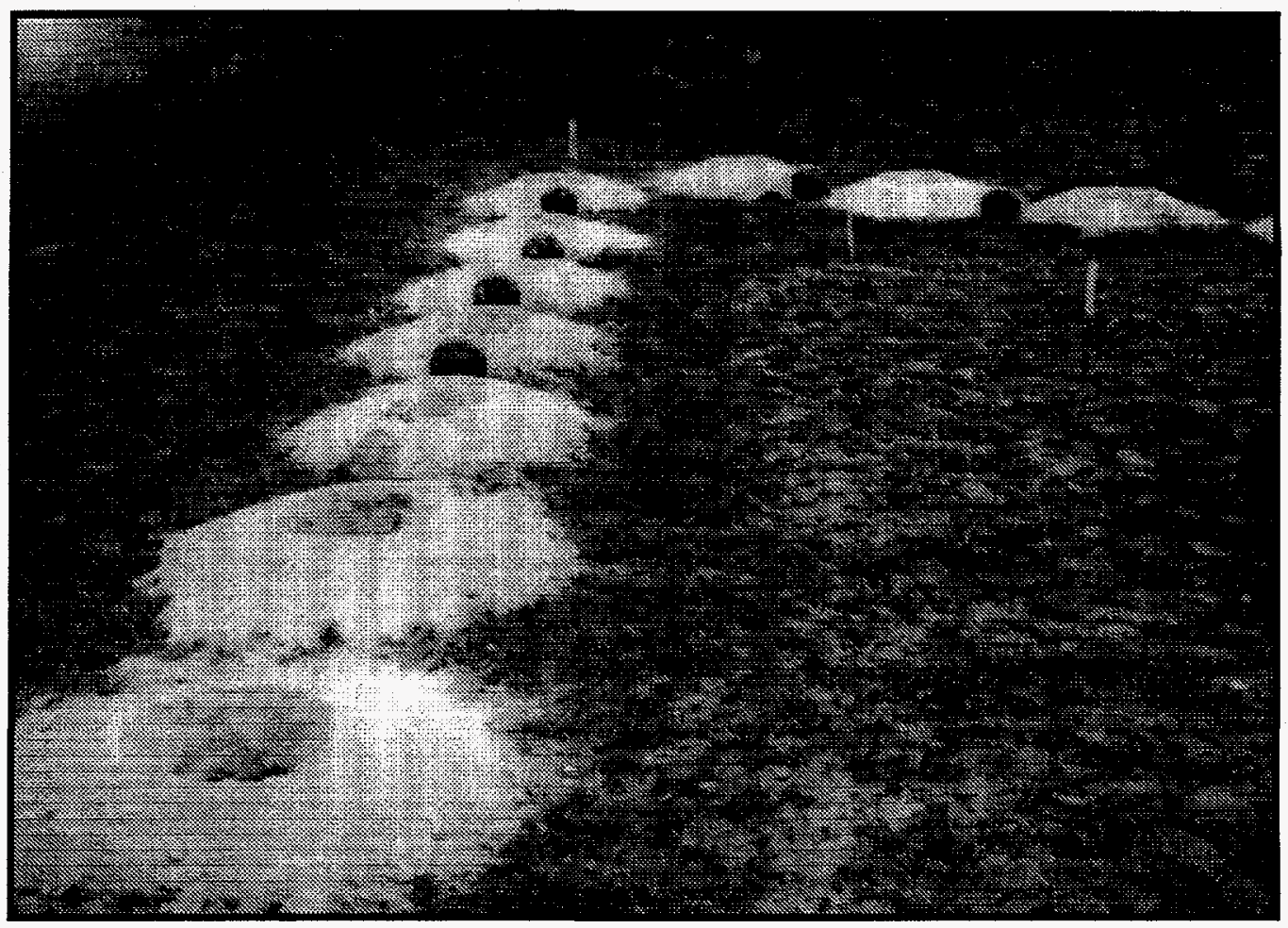

Figure 28. Plastic Spheres in Area 2 Before Burial

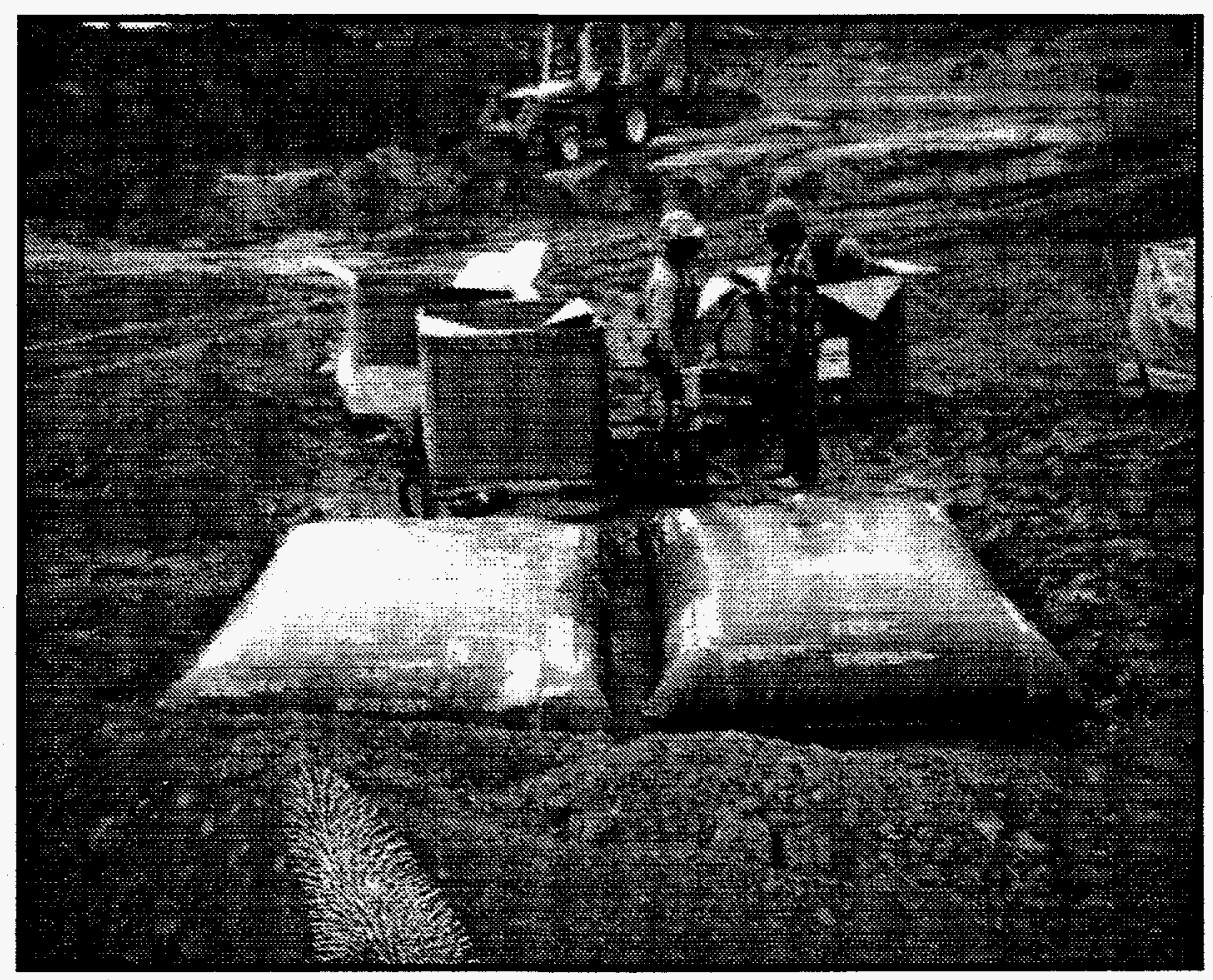

Figure 29. Filling Bladders With Soy Oil for Oil Cell 


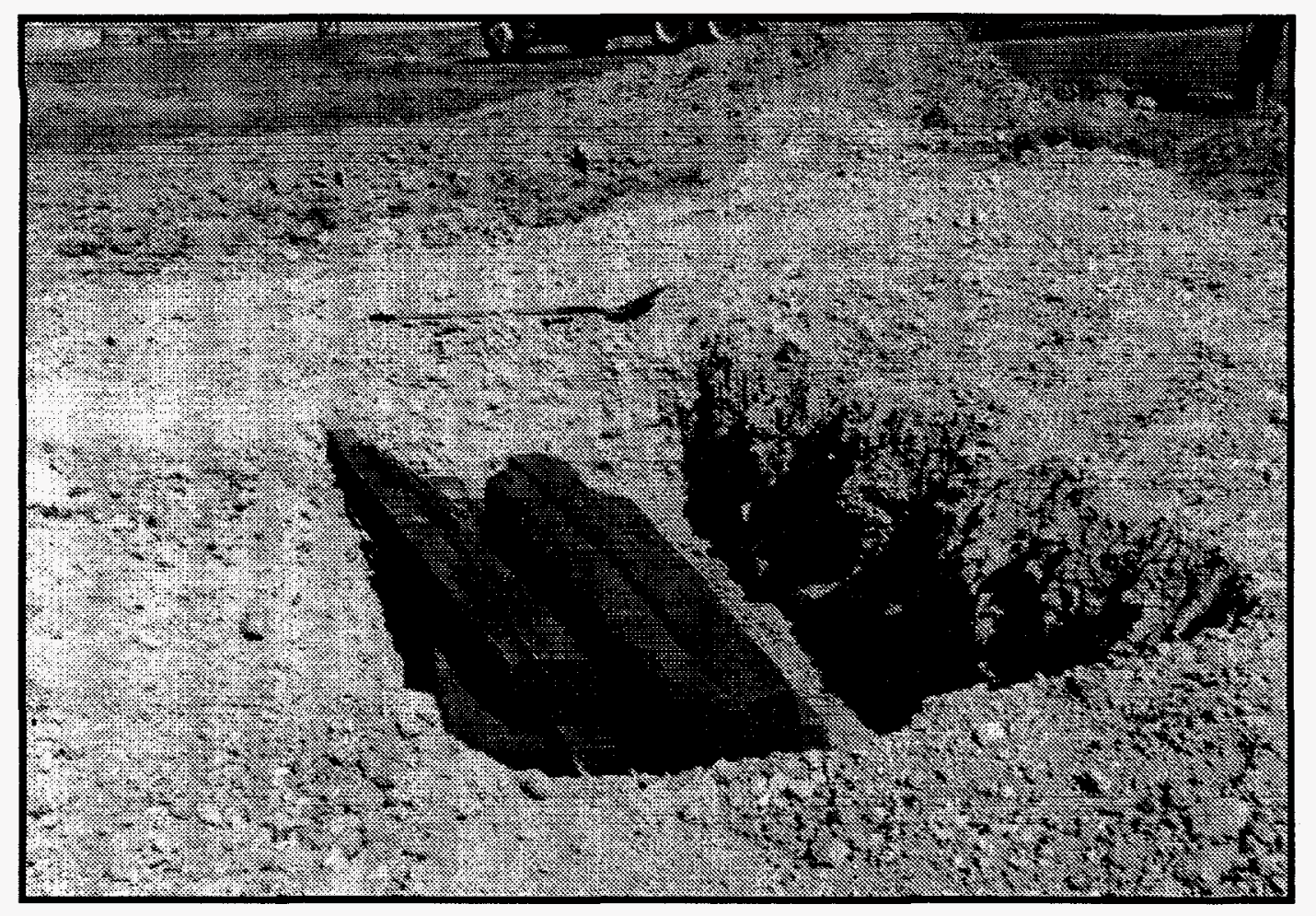

Figure 30. Wood Cell Before Burial

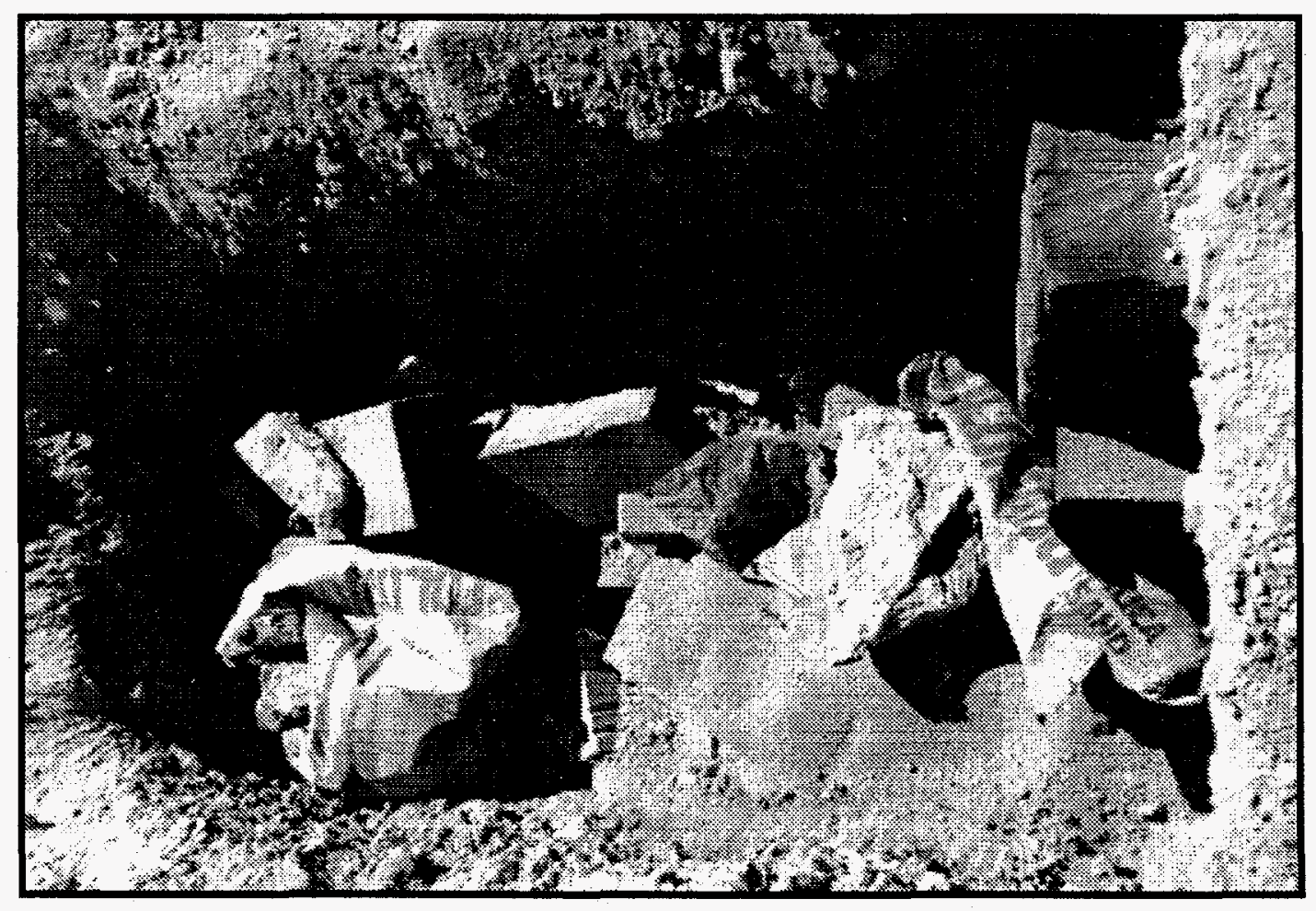

Figure 31. Trash Cell Before Burial 


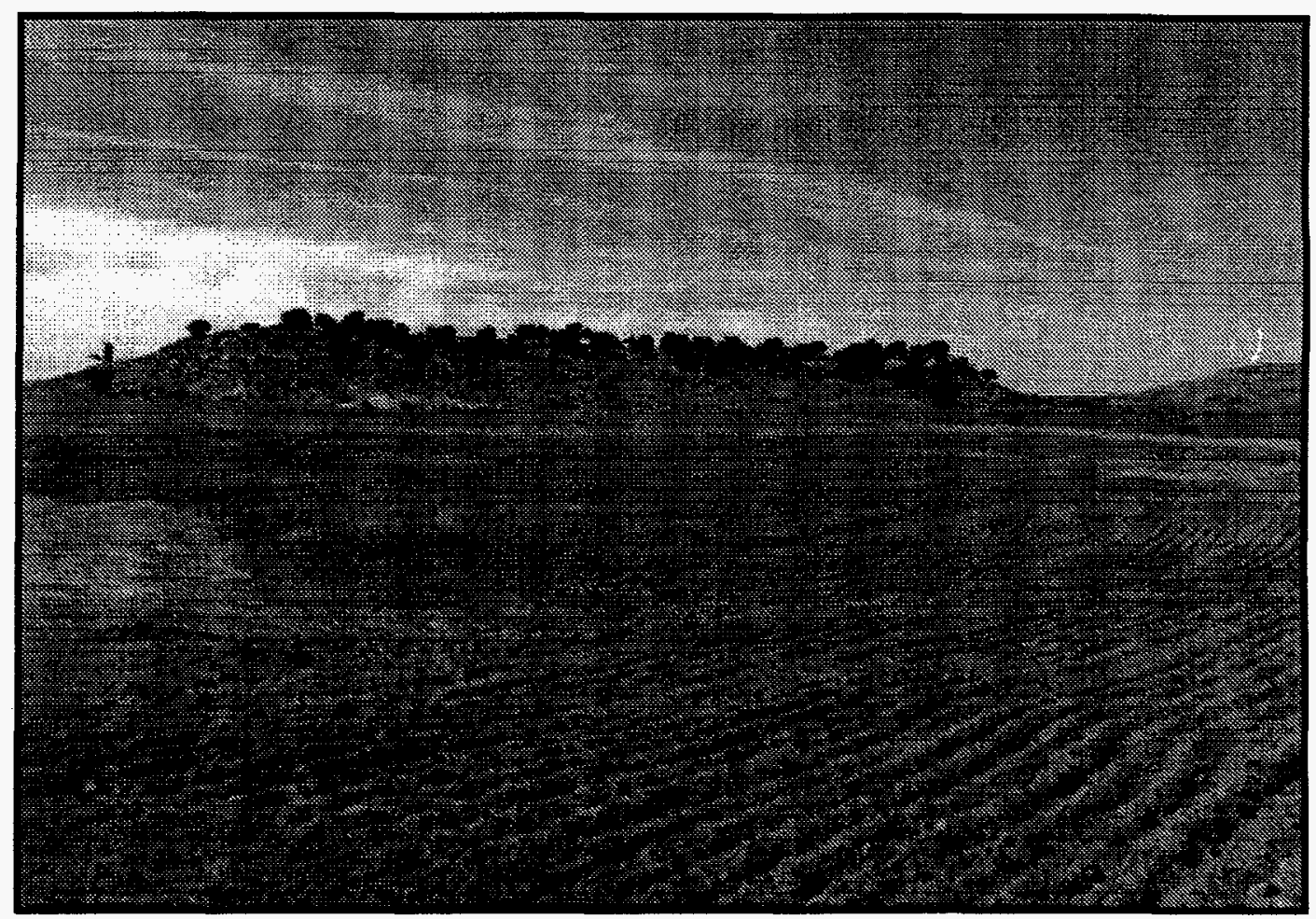

Figure 32. Recontoured Surface of Sand Pit

Dust-control measures included water spraying as shown in Figure 24. Figure 25 illustrates placement of the clay layer in the Clay Pit (Area 5), while Figure 26 illustrates placement of one of the metal sheet targets in the clay layer.

Figure 27 shows a workman emplacing a 0.5 -m-diameter steel sphere in an augered borehole in Area 6 , which contains steel spheres of different diameters at different depths and spacings. Figure 28 presents some of the plastic spheres awaiting emplacement in boreholes in one of the triangular patterns in Area 2. Figure 29 shows the process of filling nylon-reinforced plastic bladders with soy oil for the oil cell in the Sand Pit. Figure 30 presents the wood cell in the Clay Pit, while Figure 31 illustrates the "trash cell" in the Clay Pit. Figure 32 shows the recontoured surface of the Sand Pit after completion of construction. Note the striations on the surface follow the elevation contours to minimize erosion from rain water. Revegetation of the surface will be conducted in the fall when conditions are more favorable for seed germination.

During the construction, soil samples were collected from test areas where the intended use made it desirable to determine soil composition (e.g., mineralogy, grain-size distribution, clay fraction, clay type). Test areas sampled include the clay layer in the Clay Pit, sand in the Sand Pit, and auger cuttings from Areas 2 and 3. This soil information should aid in analysis and interpretation of GPR, EM, and $\mathrm{R} / \mathrm{IP}$ surveys. The samples were analyzed in the GJPO Analytical Laboratory for loss on drying, grain size, bulk mineral, and clay mineral.

Seven soil samples were submitted to the GJPO Analytical Laboratory for analysis. Table 3 lists the sample locations, collection parameters, and major analytical results. Detailed results and procedures are in Appendix B, "Soil Sample Analysis Report." 
The results of loss-on-drying (LOD) analysis indicate a low moisture content for all samples that was expected after observation of the dust rising from excavation at all depths. Grain-size analyses indicate high silt/clay content for the Clay Pit and for borings from target locations A and B in Area 6. Clay samples from the Clay Pit (NCE 923) have an appreciable smectite content. Soil samples from Area 2 showed the lowest percentage of grain size-less than $1 \mathrm{~mm}$ (see Appendix B), which is interpreted as the most favorable for GPR signal penetration. This area was designed specifically for analysis of GPR surveys.

Table 3. Analytical Results for Soil Samples

\begin{tabular}{|c|c|c|c|c|c|c|}
\hline $\begin{array}{c}\text { Sample } \\
\text { Identification }\end{array}$ & Location & $\begin{array}{c}\text { Depth } \\
\text { (m) }\end{array}$ & Description & $\begin{array}{l}\quad \text { Mineral } \\
\quad \text { Abundance } \\
D=\text { Dominant } \\
\mathbf{S}=\text { Subdominant } \\
M=\text { Moderate } \\
\mathrm{m}=\text { Minor } \\
\mathbf{T}=\text { Trace }\end{array}$ & $\begin{array}{l}\text { Grain Size } \\
\text { (weight \% of sample) } \\
\text { Silt: } 0.0020-0.0625 \mathrm{~mm} \\
\text { Clay: }<0.0020 \mathrm{~mm}\end{array}$ & $\begin{array}{l}\text { Loss on } \\
\text { Drying } \\
\text { (weight \%) }\end{array}$ \\
\hline NCE 918 & Area 6 & 1 & $\begin{array}{l}\text { Composite from } \\
\text { borings at target } \\
\text { locations } C, D \text {, } \\
E \text {, and } F\end{array}$ & $\begin{array}{l}\text { Quartz (D) } \\
\text { Calcite (M) } \\
\text { K-Feldspar (m) } \\
\text { Illite (T) } \\
\text { Kaolinite (T) } \\
\text { Plagioclase (T) }\end{array}$ & $\begin{array}{l}13.68 \% \text { sitt } \\
8.48 \% \text { clay } \\
22.16 \% \text { total }\end{array}$ & 5.6 \\
\hline NCE 919 & Area 3 & $0.25-1$ & $\begin{array}{l}\text { Composite from } \\
\text { borings at target } \\
\text { locations } B, G \text {, } \\
\text { and } L\end{array}$ & $\begin{array}{l}\text { Quartz (D) } \\
\text { K-Feldspar (m) } \\
\text { Calcite (m) } \\
\text { Illite (T) } \\
\text { Kaolinite (T) } \\
\text { Plagioclase (T) }\end{array}$ & $\begin{array}{l}12.67 \% \text { silt } \\
5.96 \% \text { clay } \\
18.63 \% \text { total }\end{array}$ & 6.9 \\
\hline NCE 920 & Area 3 & 1 & $\begin{array}{l}\text { Sample from } \\
\text { boring at target } \\
\text { location } N\end{array}$ & $\begin{array}{l}\text { Quartz (D) } \\
\text { Calcite (M) } \\
\text { K-Feldspar (m) } \\
\text { Illite (T) } \\
\text { Kaolinite (T) } \\
\text { Plagioclase (T) }\end{array}$ & $\begin{array}{l}8.24 \% \text { silt } \\
6.03 \% \text { clay } \\
14.27 \% \text { total }\end{array}$ & 4.4 \\
\hline NCE 921 & Area 6 & 1 & $\begin{array}{l}\text { Composite } \\
\text { sample from } \\
\text { borings at target } \\
\text { locations } A \text { and } B\end{array}$ & $\begin{array}{l}\text { Quartz (D) } \\
\text { Calcite (S) } \\
\text { K-Feldspar (m) } \\
\text { Plagioclase (T) } \\
\text { Smectite (m) illite } \\
(T)\end{array}$ & $\begin{array}{l}6.81 \% \text { silt } \\
6.39 \% \text { clay } \\
13.20 \% \text { total }\end{array}$ & 6.9 \\
\hline NCE 922 & Area 2 & $0.25-1$ & $\begin{array}{l}\text { Composite from } \\
\text { borings to } 0.25 \text {, } \\
0.5 \text {, and } 1 \mathrm{~m}\end{array}$ & $\begin{array}{l}\text { Quartz (D) } \\
\text { Calcite (m) } \\
\text { K-Feldspar (T) } \\
\text { Plagioclase (T) } \\
\text { lllite }(T) \\
\text { Kaolinite }(T)\end{array}$ & $\begin{array}{l}15.49 \% \text { silt } \\
7.25 \% \text { clay } \\
22.74 \% \text { total }\end{array}$ & 5.7 \\
\hline NCE 923 & $\begin{array}{l}\text { Area } 5 \\
\text { (Clay Pit) }\end{array}$ & 0.5 & $\begin{array}{l}\text { Composite } \\
\text { sample from } \\
\text { clay layer }\end{array}$ & $\begin{array}{l}\text { Quartz (D) } \\
\text { Calcite (S) } \\
\text { Smectite (m) } \\
\text { llite (T) }\end{array}$ & $\begin{array}{l}3.24 \% \text { silt } \\
3.37 \% \text { clay } \\
6.61 \% \text { total }\end{array}$ & 8.5 \\
\hline NCE 924 & $\begin{array}{l}\text { Area } 4 \\
\text { (Sand Pit) }\end{array}$ & $0-0.1$ & $\begin{array}{l}\text { Composite } \\
\text { sample from } \\
\text { sandy-loam } \\
\text { surface cover }\end{array}$ & $\begin{array}{l}\text { Quartz (D) } \\
\text { Calcite (M) } \\
\text { K-Feldspar (T) } \\
\text { Plagioclase (T) } \\
\text { lllite (T) } \\
\text { Kaolinite }(T)\end{array}$ & $\begin{array}{l}17.83 \% \text { silt } \\
\frac{8.45 \% \text { clay }}{26.28 \% \text { total }}\end{array}$ & 5.2 \\
\hline
\end{tabular}




\section{As-Built Specifications}

Figure 4 shows the relative layout of test areas and targets in the Rabbit Valley GPER. Tables 4 through 11 and Figures A-1 through A-9 (Appendix A) describe specific as-built target locations, orientations, and depths.

\section{A. Test Area 1}

Test Area 1 is designed to test magnetic and electromagnetic methods with needle-like ferromagnetic bodies. Figure A-1 shows the layout of targets and Table 4 presents target details. Targets are emplaced in boreholes and shallow trenches so that the uppermost portion of each target is a known depth (centimeters $[\mathrm{cm}]$ ) below the natural grade.

\section{B. Test Area 2}

Test Area 2 is designed for testing of high-frequency EM (GPR, etc.) and high-resolution, shallow electrical methods. It contains nonmetallic and metallic spheres in layered, nested geometric patterns. Figure A-2 (Appendix A) shows the layout of the targets; Table 5 presents details of the targets; and Figure 33 shows locations of targets in individual auger holes backfilled with the original blended and compacted soil. The triangular deployment patterns for the three layers of spheres are centered at stations 235 West and 455 South with the apex of each triangle to the north.

\section{Test Area 3}

Test Area 3 is designed for testing magnetic and EM methods on tabular and spherical bodies of different materials. Figure A-3 (Appendix A) shows the layout of the targets in the pit; Table 6 presents

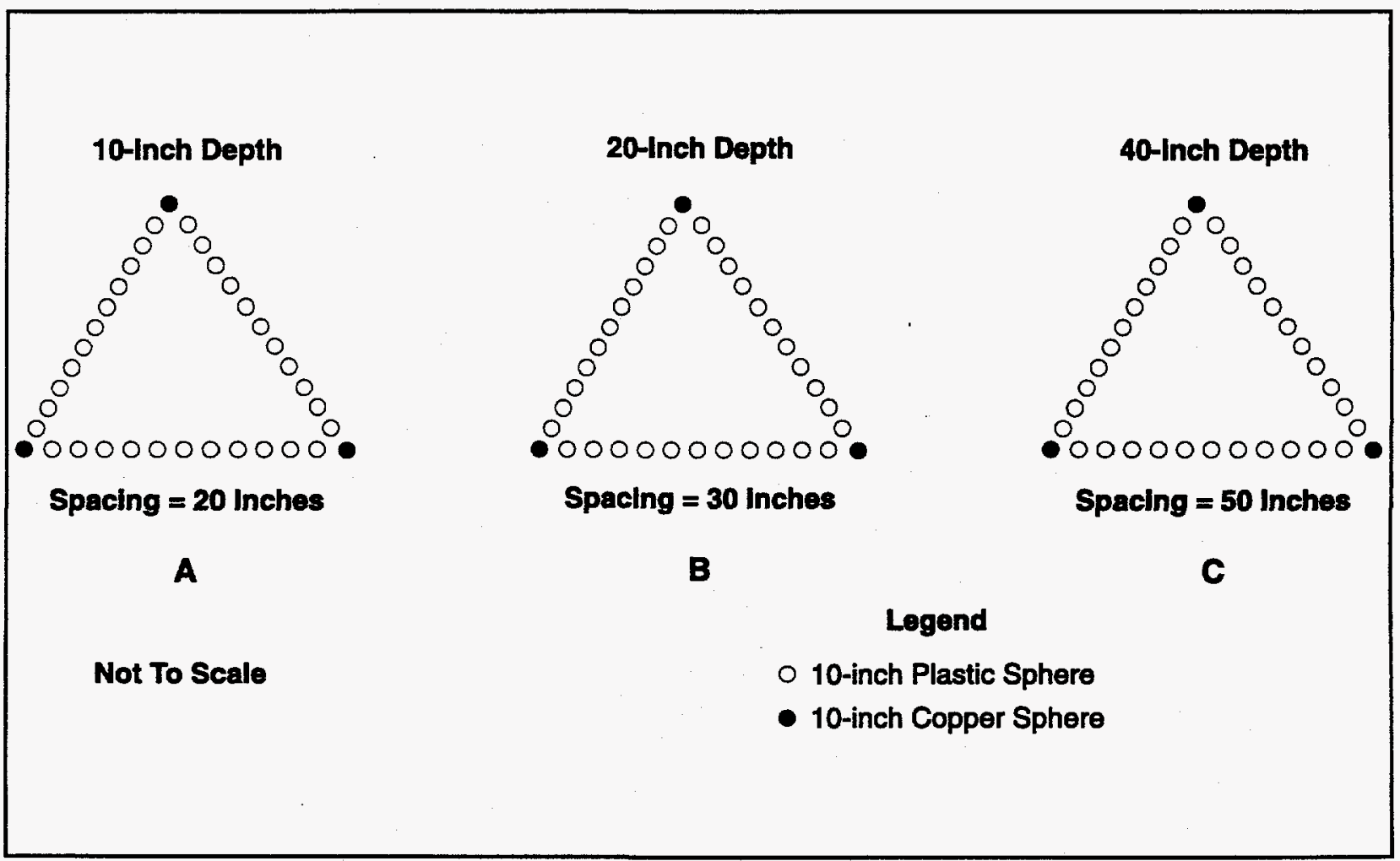

Figure 33. Deployment Pattern of Targets in Test Area 2 
Table 4. Test Area 1 Target Information

\begin{tabular}{|c|c|c|c|}
\hline Target & Description & Target Location & Orientation/Depth $\pm 1.3 \mathrm{~cm}$ \\
\hline A & $\begin{array}{l}\text { Steel pipe } \\
\text { Diameter: } 10.2 \mathrm{~cm} \\
\text { Length: } 12.8 \mathrm{~m}\end{array}$ & $-395,-320$ & Vertical/22.9 $\mathrm{cm}$ to top \\
\hline B & $\begin{array}{l}\text { Steel pipe } \\
\text { Diameter: } 10.2 \mathrm{~cm} \\
\text { Length: } 6.4 \mathrm{~m}\end{array}$ & $-335,-320$ & $\begin{array}{l}\text { Horizontal, northeast-southwest } \\
25.4 \mathrm{~cm} \text { to top }\end{array}$ \\
\hline c & $\begin{array}{l}\text { Solid steel cylinder } \\
\text { Diameter: } 11.4 \mathrm{~cm} \\
\text { Length: } 1.59 \mathrm{~m}\end{array}$ & $-275,-320$ & Dipping $67^{\circ}$ to north $/ 25.4 \mathrm{~cm}$ to top \\
\hline D & $\begin{array}{l}\text { Steel pipe wrapped with No. } 12 \text { AWG } \\
\text { insulated wire at rate of } 13 \text { turns } \\
\text { per meter: } \\
\text { Diameter: } 10.2 \mathrm{~cm} \\
\text { Length: } 6.4 \mathrm{~m}\end{array}$ & $-365,-330$ & Horizontal, east-west $/ 25.4 \mathrm{~cm}$ to top \\
\hline E & $\begin{array}{l}\text { Two-piece steel pipe weided } \\
\text { end-to-end (length equals } 12.8 \mathrm{~m} \text { ) } \\
\text { Diameter: } 10.2 \mathrm{~cm} \\
\text { Length: } 6.4 \mathrm{~m} \text { each pipe piece }\end{array}$ & $-215,-320$ & Horizontal, east-west $/ 44.5 \mathrm{~cm}$ to top \\
\hline$F$ & $\begin{array}{l}\text { Two-piece steel pipe welded } \\
\text { end-to-end (length equals } 12.8 \mathrm{~m} \text { ) } \\
\text { Diameter: } 10.2 \mathrm{~cm} \\
\text { Length: } 6.4 \mathrm{~m} \text { each piece }\end{array}$ & $-185,-320$ & Horizontal, north-south $/ 62.2 \mathrm{~cm}$ to top \\
\hline G & $\begin{array}{l}\text { Solid steel cylinder } \\
\text { Diameter: } 11.4 \mathrm{~cm} \\
\text { Length: } 1.59 \mathrm{~m}\end{array}$ & $-245,-320$ & Dipping $23^{\circ}$ to south $/ 25.4 \mathrm{~cm}$ to top \\
\hline H & $\begin{array}{l}\text { Six pieces of steel (piled in } \\
\text { a pyramid) } \\
\text { Diameter: } 10.2 \mathrm{~cm} \text { (each piece) } \\
\text { Length: } 6.4 \mathrm{~m}\end{array}$ & $-305,-320.5$ & East-west $/ 27.9 \mathrm{~cm}$ to top of stack \\
\hline
\end{tabular}

Table 5. Test Area 2 Target Information

\begin{tabular}{|c|c|c|c|}
\hline Target & Description & Spacing & Depth $\pm 1.3 \mathrm{~cm}$ \\
\hline A & $\begin{array}{l}33 \text { solid plastic spheres (bowling balls) } \\
\text { Diameter: } 20.3 \mathrm{~cm} \text {, spaced } 25.4 \mathrm{~cm} \text { edge-to-edge }\end{array}$ & Diagram A in Figure 33 & $\begin{array}{l}25.4 \mathrm{~cm} \text { to topmost } \\
\text { surface }\end{array}$ \\
\hline B & $\begin{array}{l}33 \text { solid plastic spheres (bowling balls) } \\
\text { Diameter: } 20.3 \mathrm{~cm} \text {, spaced } 50.8 \mathrm{~cm} \text { edge-to-edge }\end{array}$ & Diagram $B$ in Figure 33 & $\begin{array}{l}50.8 \mathrm{~cm} \text { to topmost } \\
\text { surface }\end{array}$ \\
\hline c & $\begin{array}{l}33 \text { solid plastic spheres (bowling balls) } \\
\text { Diameter: } 20.3 \mathrm{~cm} \text {, spaced } 101.6 \mathrm{~cm} \text { edge-to-edge }\end{array}$ & Diagram C in Figure 33 & $\begin{array}{l}101.6 \mathrm{~cm} \text { to } \\
\text { topmost surface }\end{array}$ \\
\hline D & $\begin{array}{l}3 \text { hollow copper spheres } \\
\text { Diameter: } 25.4 \mathrm{~cm} \\
\text { Thickness: } 1.5 \text { millimeters }(\mathrm{mm})\end{array}$ & Diagram A in Figure 33 & $\begin{array}{l}25.4 \mathrm{~cm} \text { to topmost } \\
\text { surface }\end{array}$ \\
\hline$E$ & $\begin{array}{l}3 \text { hollow copper spheres } \\
\text { Diameter: } 25.4 \mathrm{~cm} \\
\text { Thickness } 1.5 \mathrm{~mm}\end{array}$ & Diagram B in Figure 33 & $\begin{array}{l}50.8 \mathrm{~cm} \text { to topmost } \\
\text { surface }\end{array}$ \\
\hline$F$ & $\begin{array}{l}3 \text { hollow copper spheres } \\
\text { Diameter: } 25.4 \mathrm{~cm} \\
\text { Thickness } 1.5 \mathrm{~mm}\end{array}$ & Diagram C in Figure 33 & $\begin{array}{l}101.8 \mathrm{~cm} \text { to } \\
\text { topmost surface }\end{array}$ \\
\hline
\end{tabular}


Table 6. Test Area 3 Target Information

\begin{tabular}{|c|c|c|c|}
\hline Target & Description & Target Location & Orientation/Depth $\pm 1.3 \mathrm{~cm}$ \\
\hline A & $\begin{array}{l}\text { Solid steel disk } \\
\text { Diameter: } 69.9 \mathrm{~cm} \\
\text { Thickness: } 3.8 \mathrm{~cm}\end{array}$ & $-255,-390$ & Horizontal/25.4 cm \\
\hline B & $\begin{array}{l}\text { Hollow glass sphere } \\
\text { Diameter: } 25.4 \mathrm{~cm} \\
\text { Thickness: } \approx 2.5 \text { millimeter }(\mathrm{mm})\end{array}$ & $-260,-390$ & $125.4 \mathrm{~cm}$ \\
\hline$c$ & $\begin{array}{l}\text { Hollow copper sphere } \\
\text { Diameter: } 25.4 \mathrm{~cm} \\
\text { Thickness: } 1.5 \mathrm{~mm}\end{array}$ & $-265,-390$ & $125.4 \mathrm{~cm}$ \\
\hline$D$ & $\begin{array}{l}\text { Hollow clay sphere } \\
\text { Diameter: } 25.4 \mathrm{~cm} \\
\text { Thickness: } \approx 5 \mathrm{~mm}\end{array}$ & $-270,-390$ & $/ 25.4 \mathrm{~cm}$ \\
\hline E & $\begin{array}{l}\text { Hollow steel sphere } \\
\text { Diameter: } 25.4 \mathrm{~cm} \\
\text { Thickness: } 3.3 \mathrm{~mm}\end{array}$ & $-275,-390$ & $125.4 \mathrm{~cm}$ \\
\hline$F$ & $\begin{array}{l}\text { Solid steel disk } \\
\text { Diameter: } 69.9 \mathrm{~cm} \\
\text { Thickness: } 3.8 \mathrm{~cm}\end{array}$ & $-255,-395$ & Horizontal $/ 49.5 \mathrm{~cm}$ \\
\hline$G$ & $\begin{array}{l}\text { Hollow glass sphere } \\
\text { Diameter: } 25.4 \mathrm{~cm} \\
\text { Thickness: } \approx 2.5 \mathrm{~mm}\end{array}$ & $-260,-395$ & $150.8 \mathrm{~cm}$ \\
\hline $\mathrm{H}$ & $\begin{array}{l}\text { Hollow copper sphere } \\
\text { Diameter: } 25.4 \mathrm{~cm} \\
\text { Thickness: } 1.5 \mathrm{~mm}\end{array}$ & $-265,-395$ & $150.8 \mathrm{~cm}$ \\
\hline 1 & $\begin{array}{l}\text { Hollow clay sphere } \\
\text { Diameter: } 25.4 \mathrm{~cm} \\
\text { Thickness: } \approx 5 \mathrm{~mm}\end{array}$ & $-270,-395$ & $/ 50.8 \mathrm{~cm}$ \\
\hline$J$ & $\begin{array}{l}\text { Hollow steel sphere } \\
\text { Diameter: } 25.4 \mathrm{~cm} \\
\text { Thickness: } 3.3 \mathrm{~mm}\end{array}$ & $-275,-395$ & $150.8 \mathrm{~cm}$ \\
\hline K & $\begin{array}{l}\text { Solid steel disk } \\
\text { Diameter: } 69.9 \mathrm{~cm} \\
\text { Thickness: } 3.8 \mathrm{~cm}\end{array}$ & $-255,-400$ & Horizontal/99.1 cm \\
\hline L & $\begin{array}{l}\text { Hollow glass sphere } \\
\text { Diameter: } 25.4 \mathrm{~cm} \\
\text { Thickness: } \approx 2.5 \mathrm{~mm}\end{array}$ & $-260,-400$ & $/ 101.6 \mathrm{~cm}$ \\
\hline$M$ & $\begin{array}{l}\text { Hollow copper sphere } \\
\text { Diameter: } 25.4 \mathrm{~cm} \\
\text { Thickness: } 1.5 \mathrm{~mm}\end{array}$ & $-265,-400$ & $/ 101.6 \mathrm{~cm}$ \\
\hline N & $\begin{array}{l}\text { Hollow clay sphere } \\
\text { Diameter: } 25.4 \mathrm{~cm} \\
\text { Thickness: } \approx 5 \mathrm{~mm}\end{array}$ & $-270,-400$ & $191.4 \mathrm{~cm}$ \\
\hline o & $\begin{array}{l}\text { Hollow steel sphere } \\
\text { Diameter: } 25.4 \mathrm{~cm} \\
\text { Thickness: } 3.3 \mathrm{~mm}\end{array}$ & $-275,-400$ & $/ 104.1 \mathrm{~cm}$ \\
\hline
\end{tabular}


details of the targets. Spherical targets and steel disks were emplaced in auger holes and covered with the original blended and compacted soil.

\section{Test Area 4 (Sand Pit)}

Test Area 4 (Sand Pit) is one of two "soil swap" pits. It provides boundaries between dissimilar natural soils in addition to metal sheets and other targets. This pit is designed primarily for testing EM and electrical methods; seismic studies of the soil changes are also possible. The pit excavation is $50 \mathrm{~m}$ long by $30 \mathrm{~m}$ wide by $1.8 \mathrm{~m}$ deep in a clay host soil. Figure 34 shows the shape of the excavation bottom with elevation contours given relative to the surface at grid point $(-260,-450)$. One end and one side have stepped vertical walls; the other end and other side have walls sloped at $45^{\circ}$. Figure 35 shows the surface of the Sand Pit after recontouring. Elevations are referenced to the same point $(-260,-450)$. Table 7 presents coordinates, depths, and descriptions of targets; Figure A-4 (Appendix A) shows relative locations. The pit is backfilled with compacted sandy soil removed from the excavation for pit 5 . Pit corner coordinates are southwest $(-310,-445)$, and northwest $(-310,-415)$, northeast $(-260,-415)$, and southeast $(-260,-445)$.

\section{E. Test Area 5 (Clay Pit)}

Test Area 5 (Clay Pit) is the other soil swap pit. It provides boundaries between two different natural soils in addition to metal sheets and other targets. This pit is designed primarily for testing EM and electrical methods; seismic studies of the soil changes are also possible. The pit excavation is $50 \mathrm{~m}$ long by $30 \mathrm{~m}$ wide by $1.8 \mathrm{~m}$ deep in a sandy host soil. One end and one side have stepped vertical walls, the other end and other side have walls sloped at $45^{\circ}$. Figure 36 presents the bottom surface elevation after excavation, while Figure 37 presents the upper surface after filling and recontouring. Table 8 presents coordinates, depths, and descriptions of targets. Figure A-5 (Appendix A) shows relative locations of the targets. The targets are covered with an $45.7-\mathrm{cm}$ layer of compacted clayey soil removed from the excavation for pit 4 . Pit corner coordinates are southwest $(-400,-433)$, northwest $(-400,-383)$, northeast $(-370,-383)$, and southeast $(-370,-433)$.

\section{F. Test Area 6}

Test Area 6 is designed to test magnetic and EM methods with spherical ferromagnetic bodies of different sizes emplaced at various spacings and depths. Figure A-6 (Appendix A) shows the layout of targets; Table 9 presents details of the targets. Targets were emplaced in augered boreholes and in a deep pit so that the uppermost portion of each target is the specified depth below the natural grade.

\section{G. Test Area 7}

Test Area 7 is designed to test GPR methods using nonmetallic pipes of different sizes. Figure A-7 shows the layout of the targets; Table 10 presents details of the targets. The pipes were emplaced in narrow trenches (similar to those excavated by a Ditch Witch) so that the upper surface is a specified depth below the natural grade.

\section{H. Test Areas 8 and 9}

Test Areas 8 and 9 are designed to test electrical and EM methods with underground electrical conductors. Test Area 8 contains an insulated copper wire with provision for grounding or not grounding the ends. Test Area 9 contains a bare copper wire grounded for its entire length. Figures A-8 and A-9 (Appendix A) show the layouts of Test Areas 8 and 9, respectively. Table 11 presents details of the targets. 


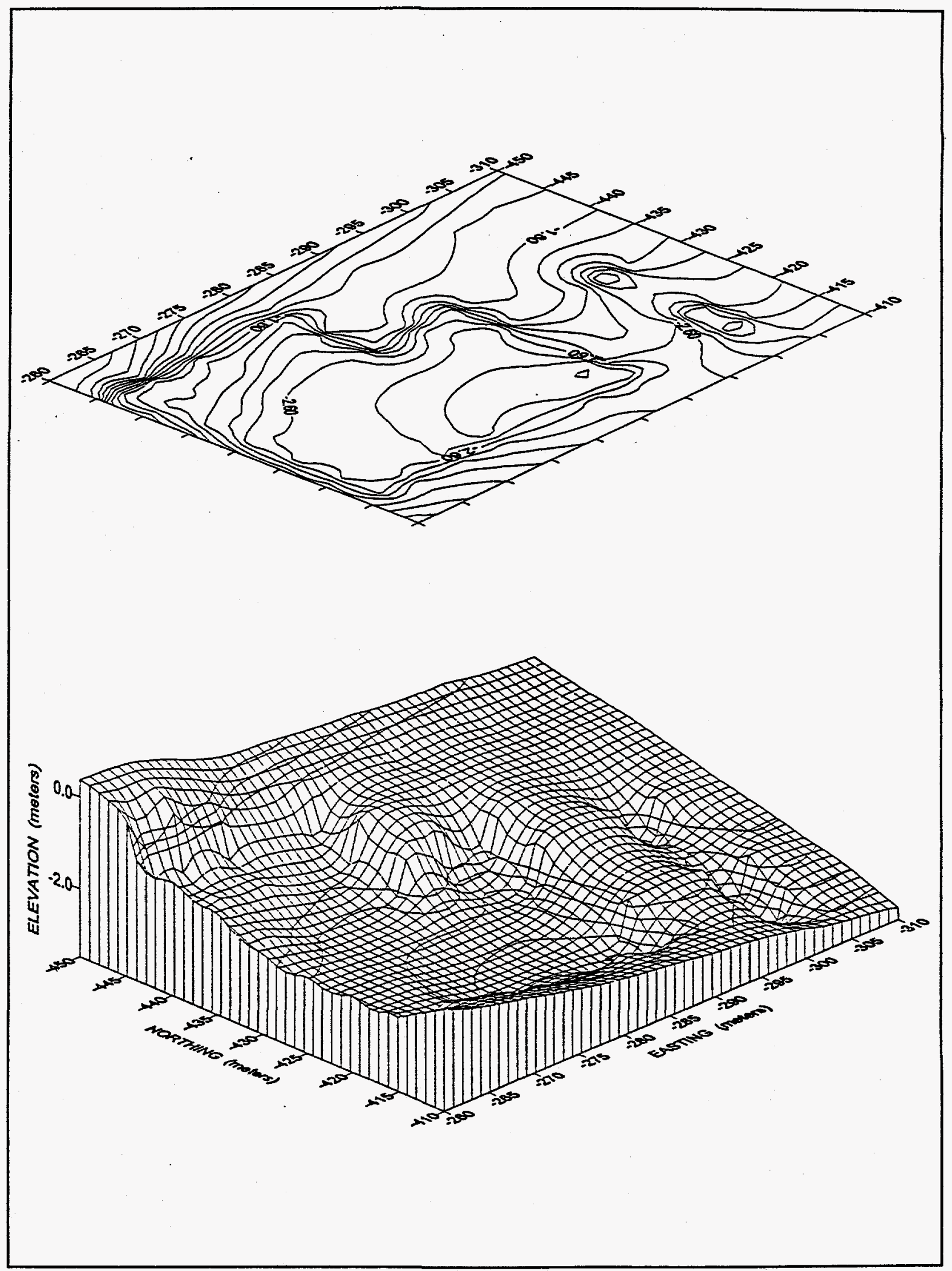

Figure 34. Bottom Surface of Sand Pit Excavation 


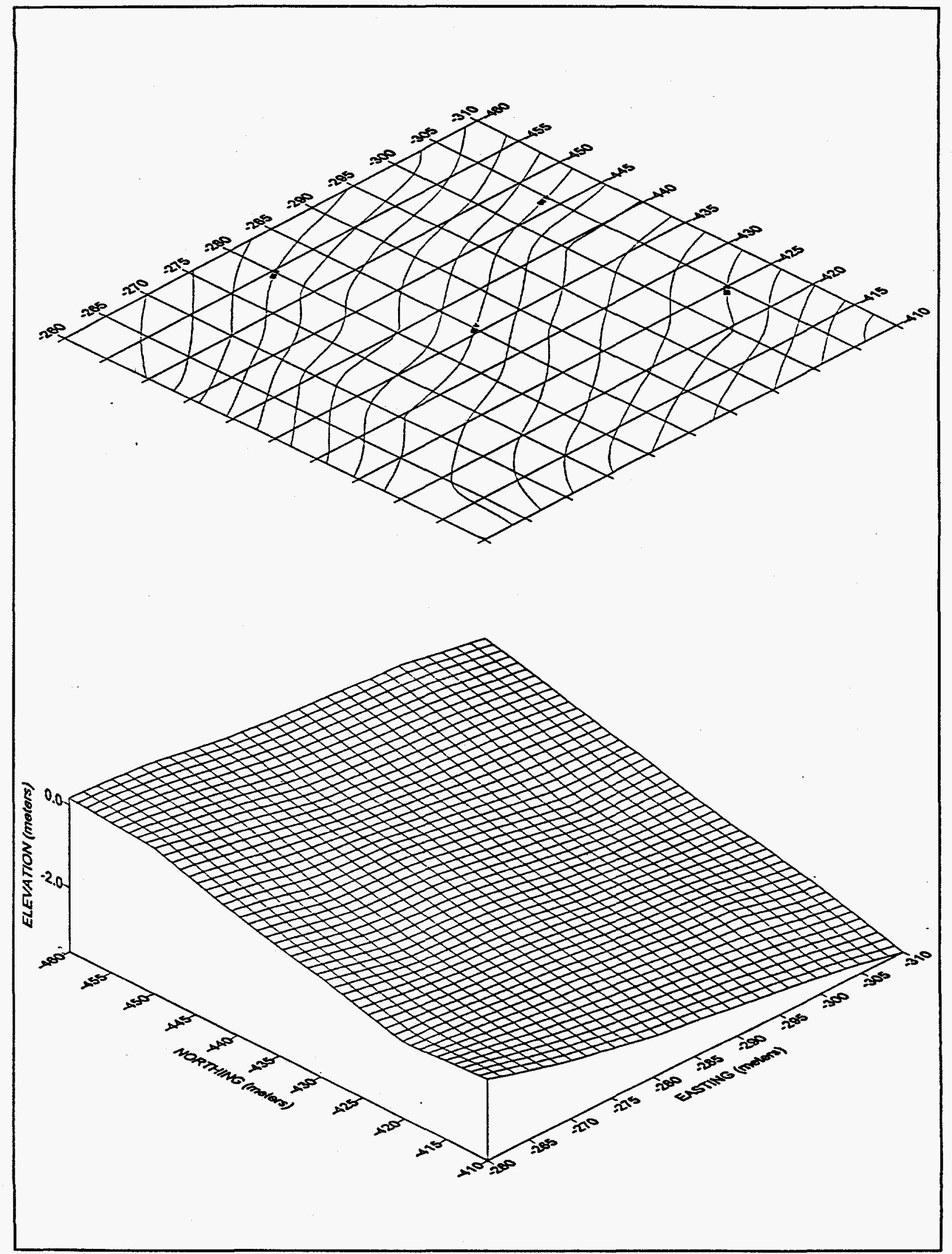

Figure 35. Upper Surface of Sand Pit After Recontouring 
Table 7. Test Area 4 Target Information

\begin{tabular}{|c|c|c|c|}
\hline Target & Description & Target Location & Orientation/Depth $\pm 10 \mathrm{~cm}$ \\
\hline A & $\begin{array}{l}\text { Aluminum plate } \\
\text { Length: } 1 \mathrm{~m} \\
\text { Width: } 1 \mathrm{~m} \\
\text { Thickness: } 1.3 \mathrm{~cm}\end{array}$ & $-267,-427$ & Horizontal/55 cm \\
\hline B & $\begin{array}{l}\text { Aluminum plate } \\
\text { Length: } 1 \mathrm{~m} \\
\text { Width: } 1 \mathrm{~m} \\
\text { Thickness: } 1.3 \mathrm{~cm}\end{array}$ & $-277,-427$ & $\begin{array}{l}\text { Dipping } 45^{\circ} \text { to north in east-west plane/ } \\
\text { center at } 78 \mathrm{~cm}\end{array}$ \\
\hline c & $\begin{array}{l}\text { Aluminum plate } \\
\text { Length: } 1 \mathrm{~m} \\
\text { Width: } 1 \mathrm{~m} \\
\text { Thickness: } 1.3 \mathrm{~cm}\end{array}$ & $-287,-427$ & Vertical in east-west plane/center at $88 \mathrm{~cm}$ \\
\hline D & $\begin{array}{l}\text { Steel plate } \\
\text { Length: } 1 \mathrm{~m} \\
\text { Width: } 1 \mathrm{~m} \\
\text { Thickness: } 1.3 \mathrm{~cm}\end{array}$ & $-267,-437$ & Horizontal/64 cm \\
\hline$E$ & $\begin{array}{l}\text { Steel plate } \\
\text { Length: } 1 \mathrm{~m} \\
\text { Width: } 1 \mathrm{~m} \\
\text { Thickness: } 1.3 \mathrm{~cm}\end{array}$ & $-277,-437$ & $\begin{array}{l}\text { Dipping } 45^{\circ} \text { north in east-west } \\
\text { plane/center at } 81 \mathrm{~cm}\end{array}$ \\
\hline$F$ & $\begin{array}{l}\text { Steel plate } \\
\text { Length: } 1 \mathrm{~m} \\
\text { Width: } 1 \mathrm{~m} \\
\text { Thickness: } 1.3 \mathrm{~cm}\end{array}$ & $-287,-437$ & Vertical in east-west plane/center at $98 \mathrm{~cm}$ \\
\hline G & $\begin{array}{l}\text { Steel cylinder } \\
\text { Diameter: } 9.5 \mathrm{~cm} \\
\text { Length: } 1.19 \mathrm{~m}\end{array}$ & $-297,-437$ & Horizontal $/ 50 \mathrm{~cm}$ axis north-south \\
\hline H & $\begin{array}{l}\text { Oil-filled bladder } \\
\text { Length: } 3.7 \mathrm{~m} \\
\text { Width: } 2.6 \mathrm{~m} \\
\text { Height: } 40.6 \mathrm{~cm}\end{array}$ & $-300,-421.5$ & $3.7-\mathrm{m}$ axis east-west/center at $64 \mathrm{~cm}$ \\
\hline
\end{tabular}

\section{Surveys by Other Users}

Several other users conducted surveys at the Rabbit Valley GPER during fiscal year 1994. Personnel from the DOE Special Technologies Laboratory, Santa Barbara, California, conducted GPR surveys of the site with a stepped FM-CW GPR. They also sponsored an airborne GPR survey by Airborne

Environmental Surveys of Santa Maria, California, and a vehicle-borne surface magnetic survey by Geo-Centers, Inc. of Newton Centre, Massachusettes. Personnel from Coleman Research Corporation, Orlando, Florida, collected data over five of the "old" targets at the Rabbit Valley GPER with their Earth Penetration Radar Imaging System (EPRIS), which is based on a frequency-stepped, phase-coherent radar with special data processing and imaging software. Students from Mesa State College, Grand Junction, Colorado, attended a geophysics "field camp" at the Rabbit Valley GPER and conducted surface magnetic, R/IP, IEM, and seismic surveys over the newly constructed Clay Pit area. The results of the first three (DOE-sponsored) surveys are documented in Site Characterization at the Rabbit Valley Geophysics Performance Evaluation Range, Final Report (February 1994), by Steven K. Koppenjan and Michael G. Martinez. Results of the Coleman tests are documented in EPRIS Measurements Support, Final Report (1994), prepared by the Coleman Research Corporation. Results of the Mesa State surveys have not yet been published. 


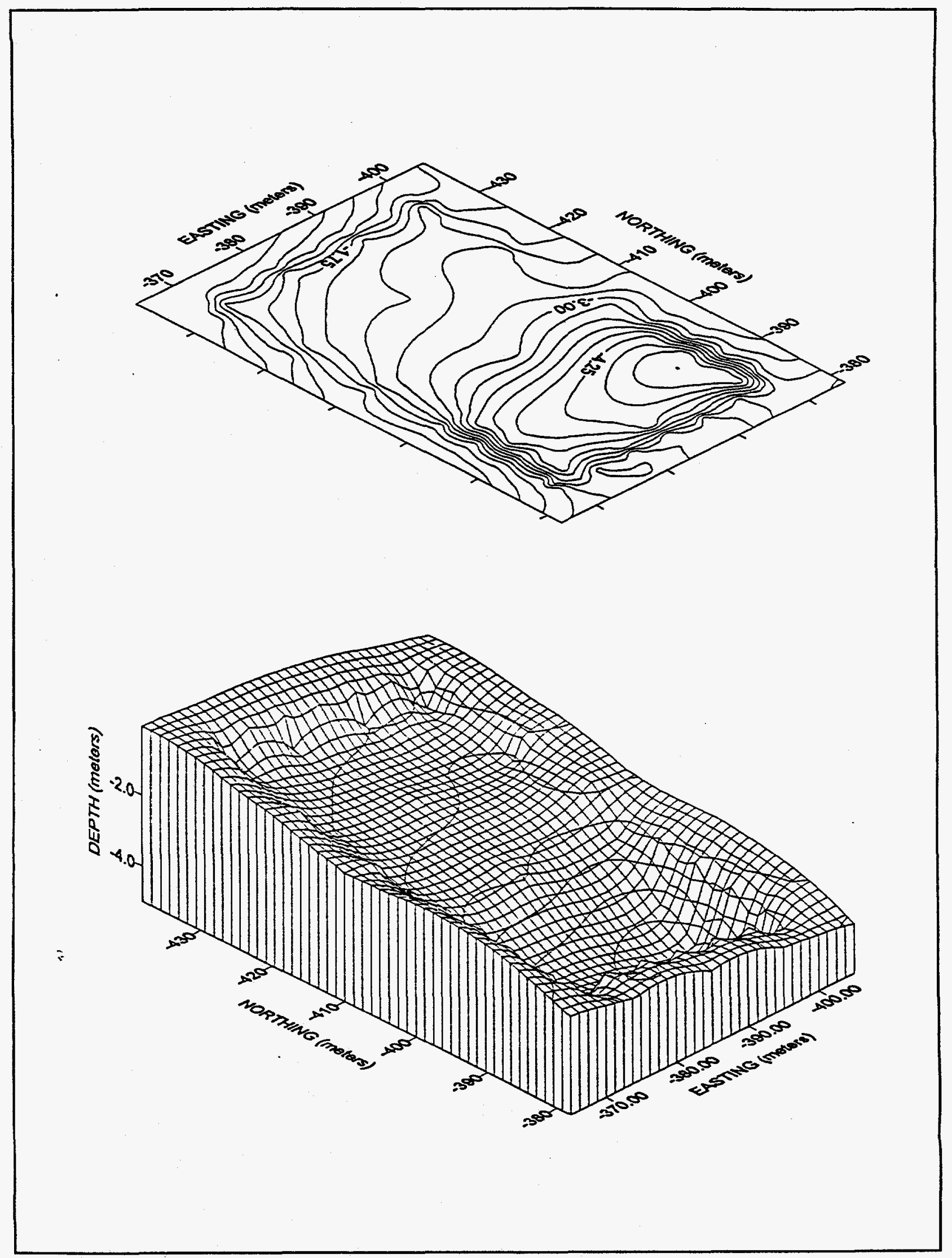

Figure 36. Bottom Surface of Clay Pit Excavation 


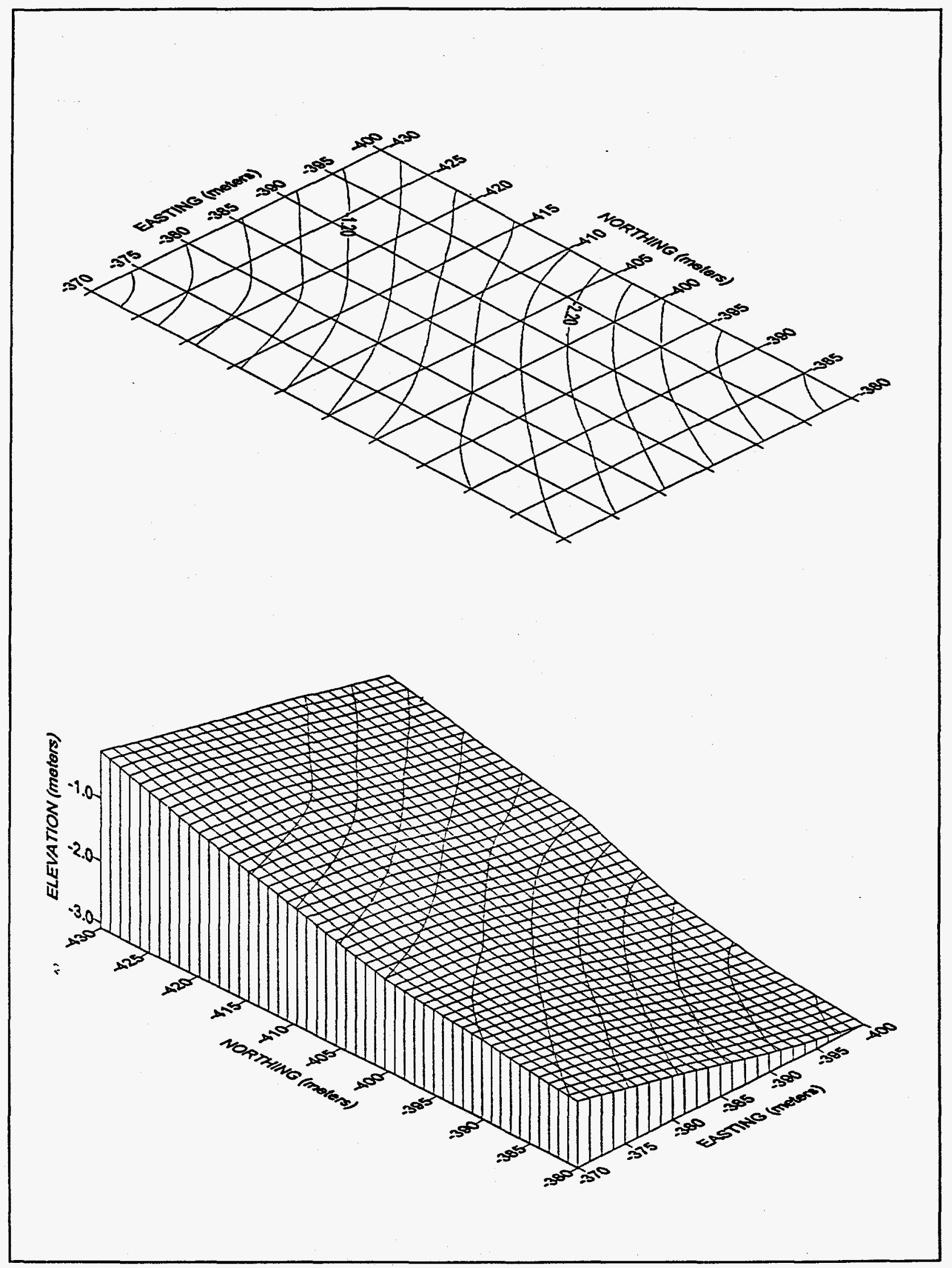

Figure 37. Upper Surface of Clay Pit After Recontouring 
Table 8. Test Area 5 Target Information

\begin{tabular}{|c|c|c|c|}
\hline Target & Description & Target Location & Orientation/Depth $\pm 10 \mathrm{~cm}$ \\
\hline A & $\begin{array}{l}\text { Aluminum plate } \\
\text { Length: } 1 \mathrm{~m} \\
\text { Width: } 1 \mathrm{~m} \\
\text { Thickness: } 1.3 \mathrm{~cm}\end{array}$ & $-391,-394$ & $\begin{array}{l}\text { Horizontal, edges north-south } \\
\text { and east-west } / 73 \mathrm{~cm}\end{array}$ \\
\hline 8 & $\begin{array}{l}\text { Aluminum plate } \\
\text { Length: } 1 \mathrm{~m} \\
\text { Width: } 1 \mathrm{~m} \\
\text { Thickness: } 1.3 \mathrm{~cm}\end{array}$ & $-391,-407$ & $\begin{array}{l}\text { Dipping } 45^{\circ} \text { to north in } \\
\text { east-west plane/center at } 94 \mathrm{~cm}\end{array}$ \\
\hline c & $\begin{array}{l}\text { Aluminum plate } \\
\text { Length: } 1 \mathrm{~m} \\
\text { Width: } 1 \mathrm{~m} \\
\text { Thickness: } 1.3 \mathrm{~cm}\end{array}$ & $-391,-420$ & $\begin{array}{l}\text { Vertical in east-west } \\
\text { plane/center at } 72 \mathrm{~cm}\end{array}$ \\
\hline - & $\begin{array}{l}\text { Steel plate } \\
\text { Length: } 1 \mathrm{~m} \\
\text { Width: } 1 \mathrm{~m} \\
\text { Thickness: } 1.3 \mathrm{~cm}\end{array}$ & $-381,-394$ & $\begin{array}{l}\text { Horizontal, edges north-south } \\
\text { and east-west } 76 \mathrm{~cm}\end{array}$ \\
\hline E & $\begin{array}{l}\text { Steel plate } \\
\text { Length: } 1 \mathrm{~m} \\
\text { Width: } 1 \mathrm{~m} \\
\text { Thickness: } 1.3 \mathrm{~cm}\end{array}$ & $-381,-407$ & $\begin{array}{l}\text { Dipping } 45^{\circ} \text { to north in } \\
\text { east-west plane/center at } 88 \mathrm{~cm}\end{array}$ \\
\hline$F$ & $\begin{array}{l}\text { Steel plate } \\
\text { Length: } 1 \mathrm{~m} \\
\text { Width: } 1 \mathrm{~m} \\
\text { Thickness: } 1.3 \mathrm{~cm}\end{array}$ & $-381,-420$ & $\begin{array}{l}\text { Vertical in east-west } \\
\text { plane/center at } 85 \mathrm{~cm}\end{array}$ \\
\hline G & $\begin{array}{l}\text { Long steel cylinder } \\
\text { Diameter: } 9.6 \mathrm{~cm} \\
\text { Length: } 1.2 \mathrm{~m}\end{array}$ & $-391,-430$ & Horizontal, axis east-west/94 cm \\
\hline $\mathrm{H}$ & $\begin{array}{l}\text { High stack of railroad ties } \\
\text { Length: } 2.7 \mathrm{~m} \\
\text { Width: } 101.6 \mathrm{~cm} \\
\text { Height: } 101.6 \mathrm{~cm}\end{array}$ & $-373,-429$ & $\begin{array}{l}2.4-\mathrm{m} \text { axis east-west/top } 6 \mathrm{~cm} \\
\text { below surface }\end{array}$ \\
\hline 1 & $\begin{array}{l}\text { "Trash pit" filled with cinder blocks, wood } \\
\text { blocks, bricks, and metal } 230-\mathrm{cm}^{3} \text { cans } \\
\text { randomly dispersed in } 454.5 \text { kilograms of } \\
\text { silica sand } \\
\text { Width: } 61 \mathrm{~cm} \\
\text { Length: } 91.4 \mathrm{~cm} \\
\text { Depth: } 1.5 \mathrm{~m}\end{array}$ & $-397,-386$ & $\begin{array}{l}1.5 \mathrm{~m} \text { to bottom, random } \\
\text { placement of objects in sand fill, } \\
\text { then fill to pit top surface }\end{array}$ \\
\hline
\end{tabular}


Table 9. Test Area 6 Target Information

\begin{tabular}{|c|c|c|c|}
\hline Target & Description & Target Location & Depth $\pm 1.3 \mathrm{~cm}$ \\
\hline A & $\begin{array}{l}\text { Steel sphere } \\
\text { Diameter: } 50.8 \mathrm{~cm} \\
\text { Thickness: } 3.3 \text { millimeters }(\mathrm{mm})\end{array}$ & $-251,-423$ & $104.1 \mathrm{~cm}$ \\
\hline B & $\begin{array}{l}\text { Steel sphere } \\
\text { Diameter: } 50.8 \mathrm{~cm} \\
\text { Thickness: } 3.3 \mathrm{~mm}\end{array}$ & $-251,-421$ & $104.1 \mathrm{~cm}$ \\
\hline c & $\begin{array}{l}\text { Steel sphere } \\
\text { Diameter: } 50.8 \mathrm{~cm} \\
\text { Thickness: } 3.3 \mathrm{~mm}\end{array}$ & $-241,-420$ & $99.1 \mathrm{~cm}$ \\
\hline D & $\begin{array}{l}\text { Steel sphere } \\
\text { Diameter: } 50.8 \mathrm{~cm} \\
\text { Thickness: } 3.3 \mathrm{~mm}\end{array}$ & $-240,-420$ & $100.3 \mathrm{~cm}$ \\
\hline E & $\begin{array}{l}\text { Steel sphere } \\
\text { Diameter: } 50.8 \mathrm{~cm} \\
\text { Thickness: } 3.3 \mathrm{~mm}\end{array}$ & $-238,-420$ & $104.1 \mathrm{~cm}$ \\
\hline$F$ & $\begin{array}{l}\text { Steel sphere } \\
\text { Diameter: } 50.8 \mathrm{~cm} \\
\text { Thickness: } 3.3 \mathrm{~mm}\end{array}$ & $-234,-420$ & $101.6 \mathrm{~cm}$ \\
\hline G & $\begin{array}{l}\text { Steel sphere } \\
\text { Diameter: } 50.8 \mathrm{~cm} \\
\text { Thickness: } 3.3 \mathrm{~mm}\end{array}$ & $-230,-420$ & $101 \mathrm{~cm}$ \\
\hline $\mathrm{H}$ & $\begin{array}{l}\text { Steel sphere } \\
\text { Diameter: } 50.8 \mathrm{~cm} \\
\text { Thickness: } 3.3 \mathrm{~mm}\end{array}$ & $-220,-420$ & $2.0 \mathrm{~m}$ \\
\hline 1 & $\begin{array}{l}\text { Steel sphere } \\
\text { Diameter: } 50.8 \mathrm{~cm} \\
\text { Thickness: } 3.3 \mathrm{~mm}\end{array}$ & $-200,-420$ & $2.5 \mathrm{~m}$ \\
\hline$\checkmark$ & $\begin{array}{l}\text { Steel sphere } \\
\text { Diameter: } 25.4 \mathrm{~cm} \\
\text { Thickness: } 3.3 \mathrm{~mm}\end{array}$ & $-200,-440$ & $3.1 \mathrm{~m}$ \\
\hline k & $\begin{array}{l}\text { Steel sphere } \\
\text { Diameter: } 1.2 \mathrm{~m} \\
\text { Thickness: } \approx 9 \mathrm{~mm}\end{array}$ & $-200,-460$ & $1.8 \mathrm{~m}$ \\
\hline
\end{tabular}

Table 10. Test Area 7 Target Information

\begin{tabular}{clcc}
\hline Target & \multicolumn{1}{c}{ Description } & Target Location & Depth $\pm 1.3 \mathrm{~cm}$ \\
\hline A & $\begin{array}{l}\text { PVC pipe } \\
\text { Diameter: } 5.1 \mathrm{~cm} \\
\end{array}$ & $-325,-330$ & $25.4 \mathrm{~cm}$ \\
Length: $3 \mathrm{~m}$ & & \\
B & $\begin{array}{l}\text { PVC pipe } \\
\text { Diameter: } 10.2 \mathrm{~cm} \\
\text { Length: } 3 \mathrm{~m}\end{array}$ & $-335,-330$ & $35.6 \mathrm{~cm}$ \\
& $\begin{array}{l}\text { PVC pipe } \\
\text { Diameter: } 20.3 \mathrm{~cm} \\
\text { Cength: } 3 \mathrm{~m}\end{array}$ & $-345,-330$ & $50.8 \mathrm{~cm}$ \\
& Len & & \\
\hline
\end{tabular}


Table 11. Test Areas 8 and 9 Target Information

\begin{tabular}{clll}
\hline Area & \multicolumn{1}{c}{ Target Description } & $\begin{array}{l}\text { Wire End } \\
\text { Location }\end{array}$ & Depth \\
\hline 8 & $\begin{array}{l}\text { Insulated No. 10 AWG copper wire with ends brought } \\
\text { to surface with stakes for grounding, as desired }\end{array}$ & $\begin{array}{l}-410,-350 \\
-410,-450\end{array}$ & $0.8 \mathrm{~m}$ \\
& $\begin{array}{l}\text { Length of wire: } 100 \mathrm{~m} \\
\text { Bare No. 10 AWG copper wire } \\
\text { Length of wire: } 57 \mathrm{~m}\end{array}$ & $\begin{array}{l}-400,-499 \\
-343,-499\end{array}$ & $0.8 \mathrm{~m}$ \\
\hline
\end{tabular}

\section{References}

Allen, J.W., 1990. Ground-Penetrating Radar Studies, prepared by UNC Geotech, Inc., for U.S. Department of Energy, Grand Junction Projects Office, Grand Junction, Colorado.

1992. Ground-Penetrating Radar Detection of Buried Caches, prepared by Chem-Nuclear Geotech, Inc. for the U.S. Department of Energy, Grand Junction Projects Office, Grand Junction, Colorado.

Coleman Research Corporation, 1994. EPRIS Measurements Support, Final Report, prepared by the Coleman Research Corporation, Orlando, Florida, for the U.S. Department of the Army, Picatinny Arsenal, New Jersey, and U.S. Department of Energy Office of Technology Development.

Koppenjan, S.K., and Martinez, M.G., 1994. Site Characterization at the Rabbit Valley Geophysics Performance Evaluation Range, Final Report, prepared by EG\&G Energy Measurements for the U.S. Department of Energy, Special Technologies Laboratory, Santa Barbara, Califormia, February.

Lesperance, L.R., to Dickerson, J.W., 1992. Vegetation Assessment Findings and Revegetation Specifications for the Rabbit Valley Test Site, Internal memorandum from Chem-Nuclear Geotech, Inc., Grand Junction, Colorado, May.

RUST Geotech Inc., 1992. Rabbit Valley Geophysics Performance Evaluation Range (GPER), FY-1993 Technical Task Plan, prepared by RUST Geotech Inc. for the U.S. Department of Energy, Grand Junction Projects Office, Grand Junction, Colorado.

1993a. Initial Report: U.S. Department of Energy Geophysical Test Beds and Range Design Specifications for the Grand Junction Projects Office Rabbit Valley Geophysics Performance Evaluation Range, prepared by RUST Geotech Inc. for the U.S. Department of Energy, Grand Junction Projects Office, Grand Junction, Colorado.

1993b. Rabbit Valley Geophysics Performance Evaluation Range (GPER), FY-1994 Technical Task Plan, prepared by RUST Geotech Inc. for the U.S. Department of Energy, Grand Junction Projects Office, Grand Junction, Colorado.

1994a. Analytical Report for Project 4RCMS2121 (Rabbit Valley GPER), prepared by Grand Junction Projects Office Analytical Laboratory, Grand Junction, Colorado, July.

1994b. Minimum Drilling Health and Safety Requirements for Operation of Small Auger, Rotary, and Core Rigs, P-GJPO-113 Rev. 3, prepared by RUST Geotech Inc. for the U.S. Department of Energy, Grand Junction Projects Office, Grand Junction, Colorado, January.

1994c. Rabbit Valley Geophysics Performance Evaluation Range (GPER) Health and Safety Plan, prepared by RUST Geotech Inc. for the U.S. Department of Energy, Grand Junction Projects Office, Grand Junction, Colorado, March. 
Sorter Construction Company, 1994a. Health and Safety Attachment 1-12-94, Revised April 25, 1994, Grand Junction, Colorado.

1994b. Rabbit Valley Geophysics Performance Evaluation Range (GPER) Health and Safety Plan, Sorter Construction Company, Grand Junction, Colorado, April.

1994c. Safety Management Plan, Revised April 1994, Sorter Construction Company, Grand

Junction, Colorado.

\section{Acknowledgments}

The author acknowledges the contributions of many others who contributed to the successful completion of the Rabbit Valley GPER-the Geotech Geophysical Projects personnel who conceived the project, especially John Dickerson who initiated the plans; Geotech program managers; Geotech Health, Safety, and Security; Geotech Procurement; and the DOE-GJPO, DOE Albuquerque Operations Office, and DOE Headquarters for sponsoring and funding the GPER. The conscientious, hard workers of Sorter Construction Company who moved the dirt, planted the targets, and finished the construction on schedule and within budget. Thanks to Michael Cote who diligently monitored construction activities and recorded as-built data for this report. 


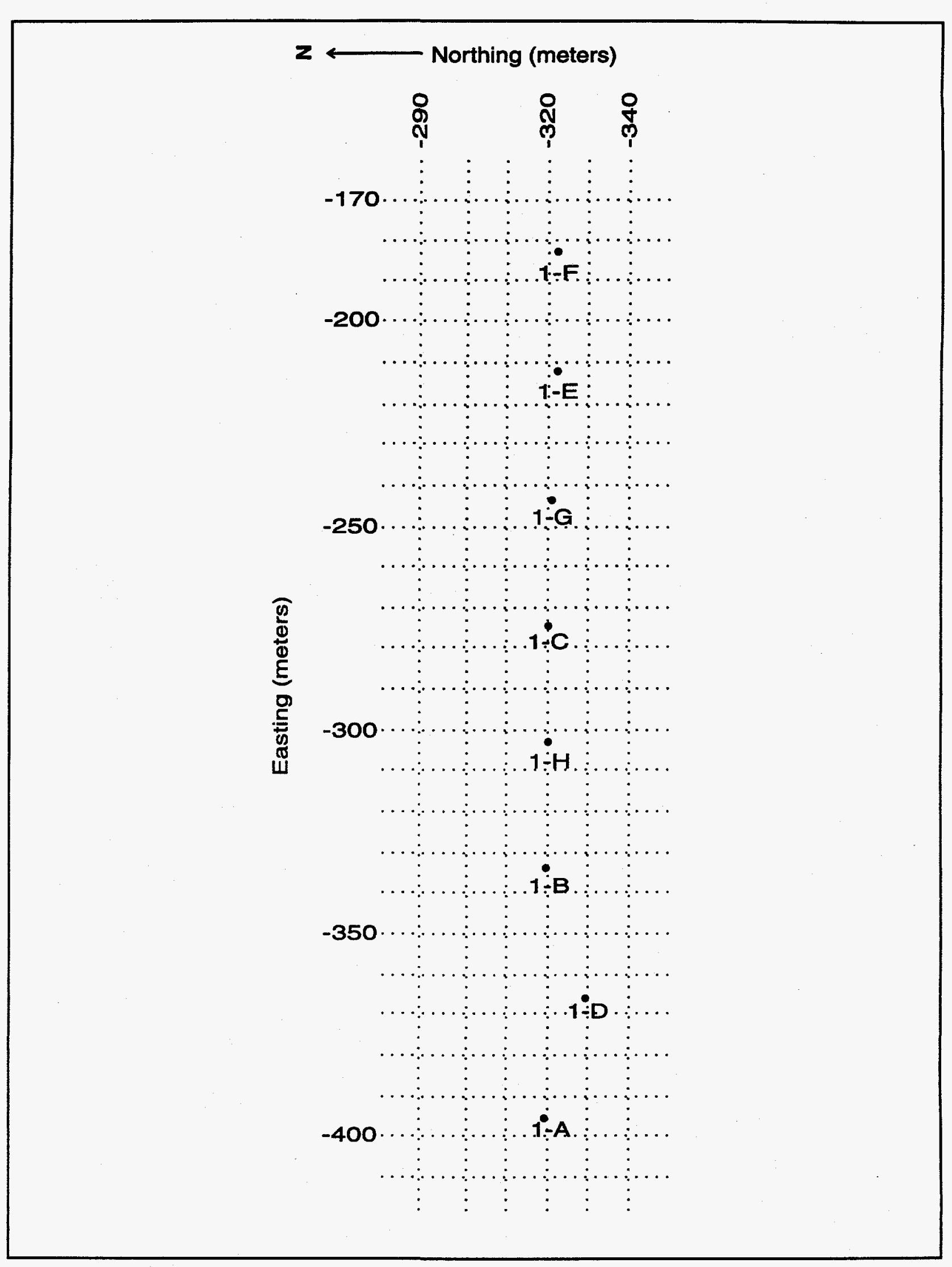

Figure A-1. Rabbit Valley GPER Area 1 


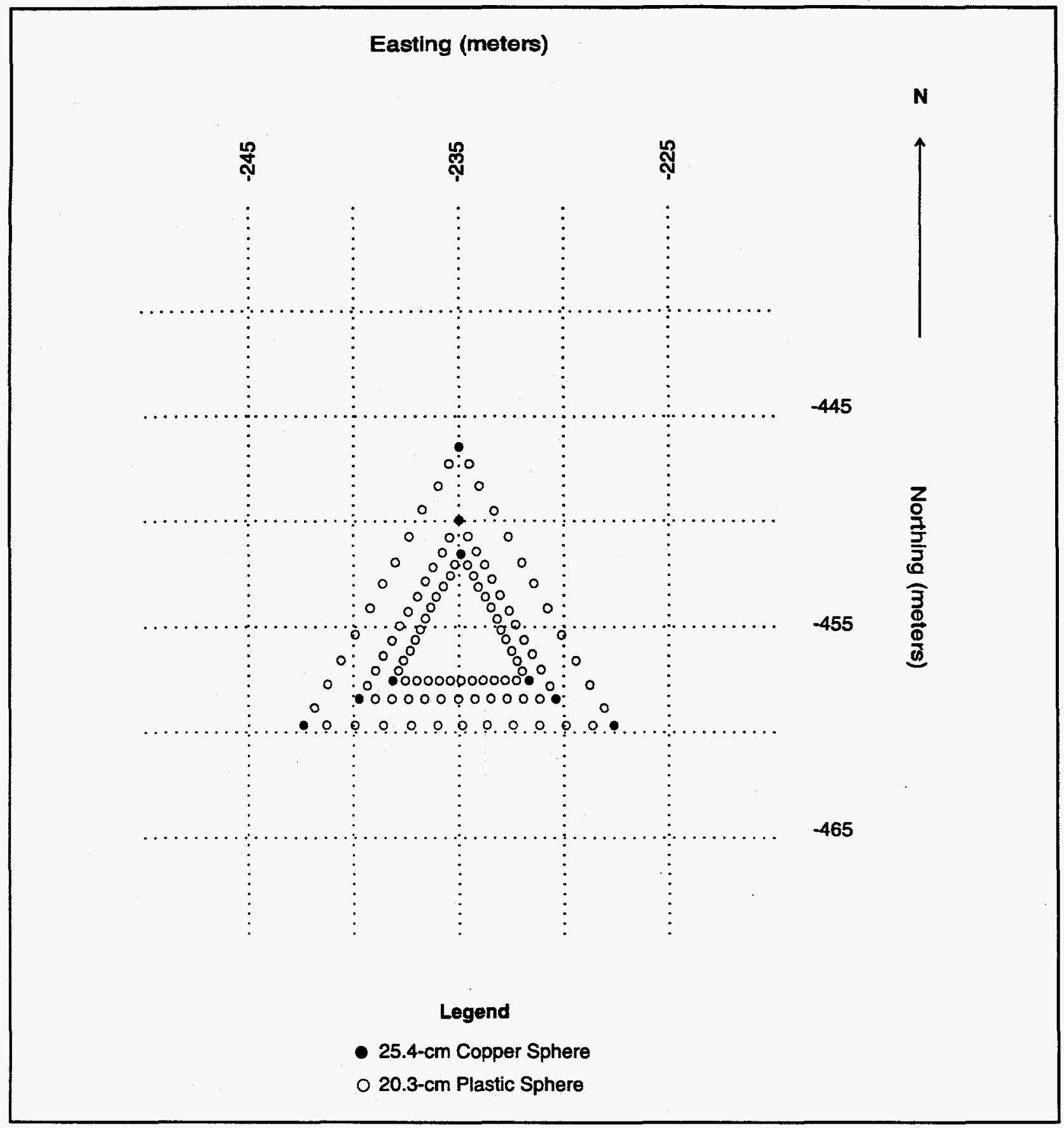

Figure A-2. Rabbit Valley GPER Area 2 


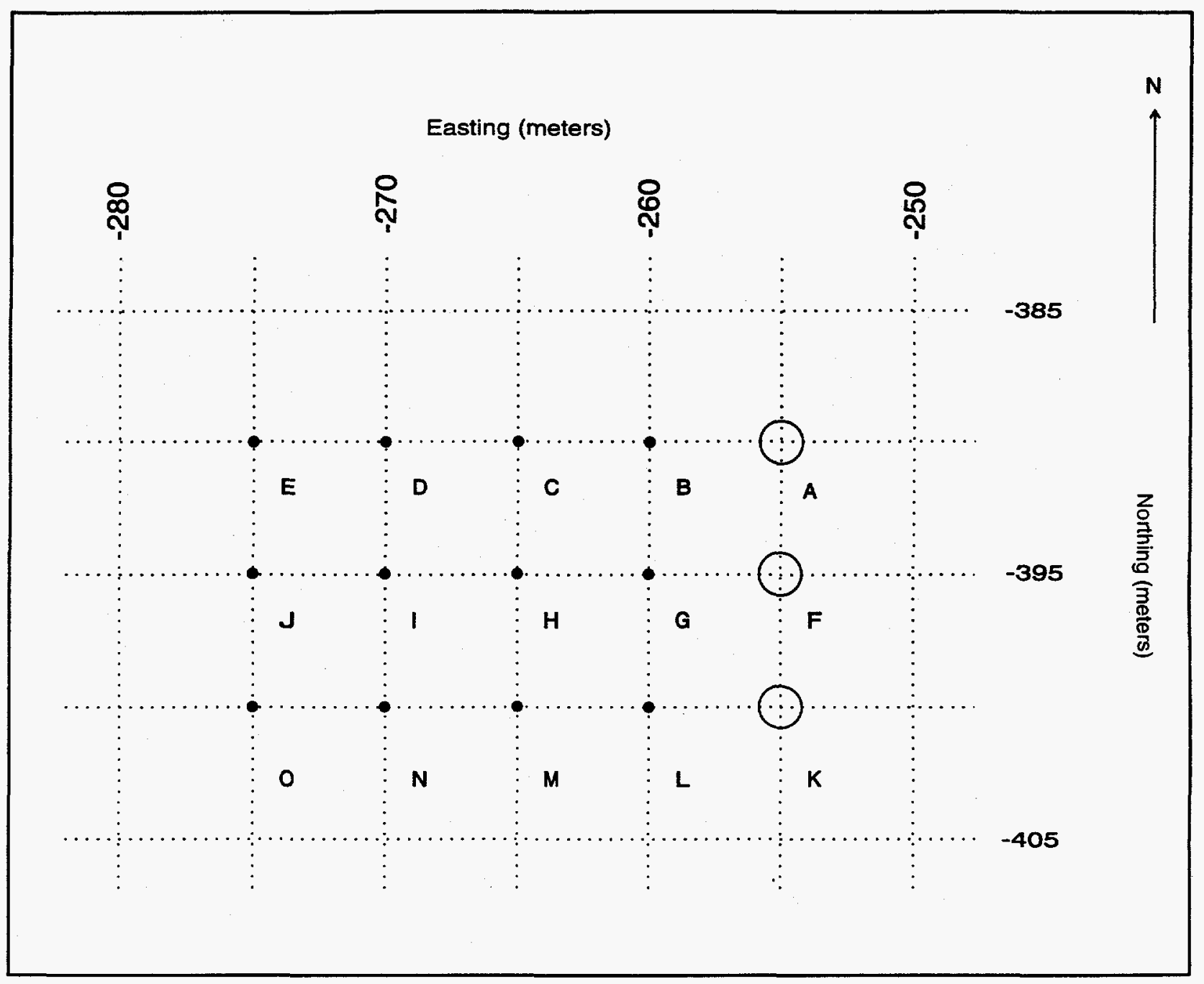

Figure A-3. Rabbit Valley GPER Area 3 


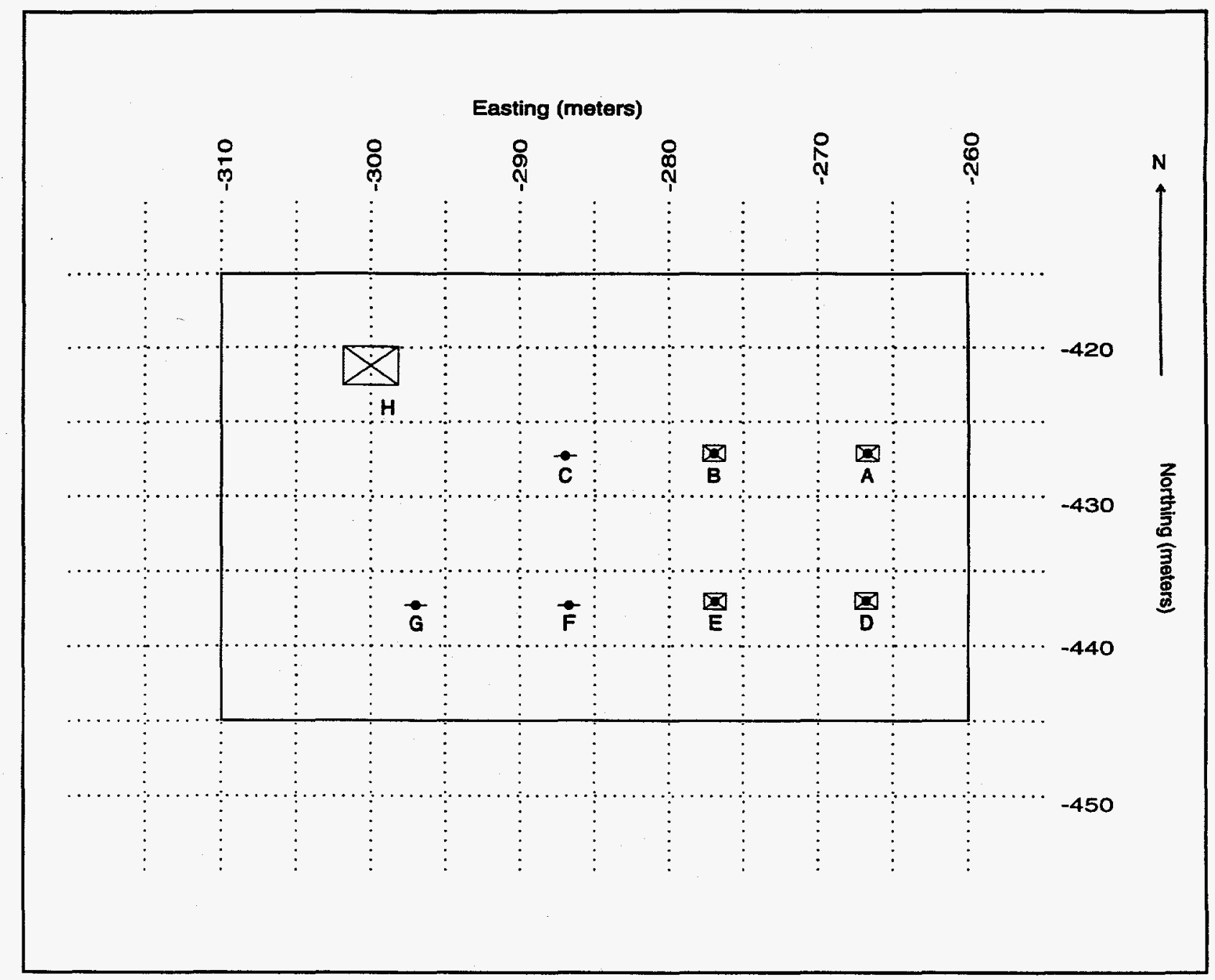

Figure A-4. Rabbit Valley GPER Area 4 


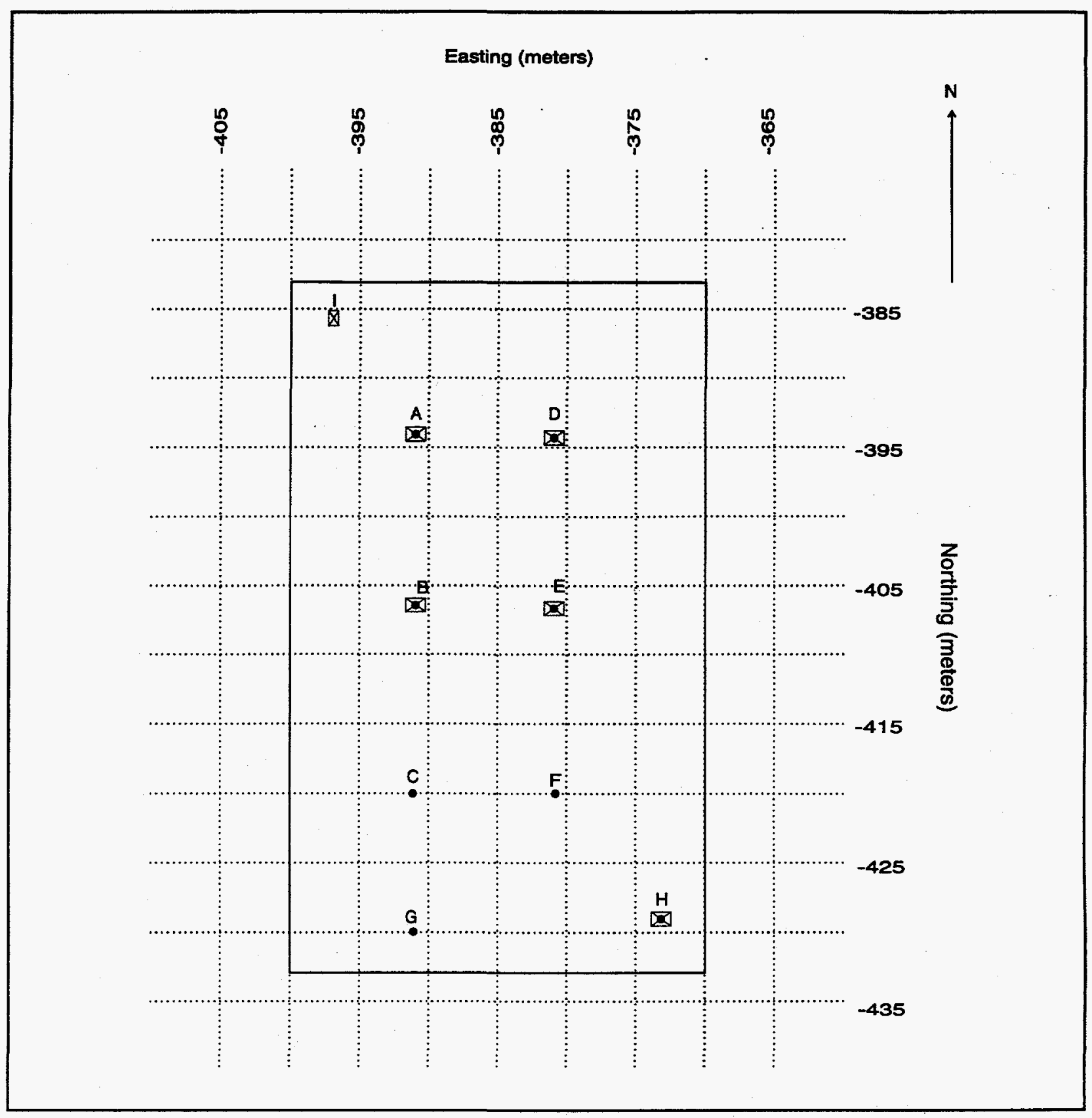

Figure A-5. Rabbit Valley GPER Area 5 


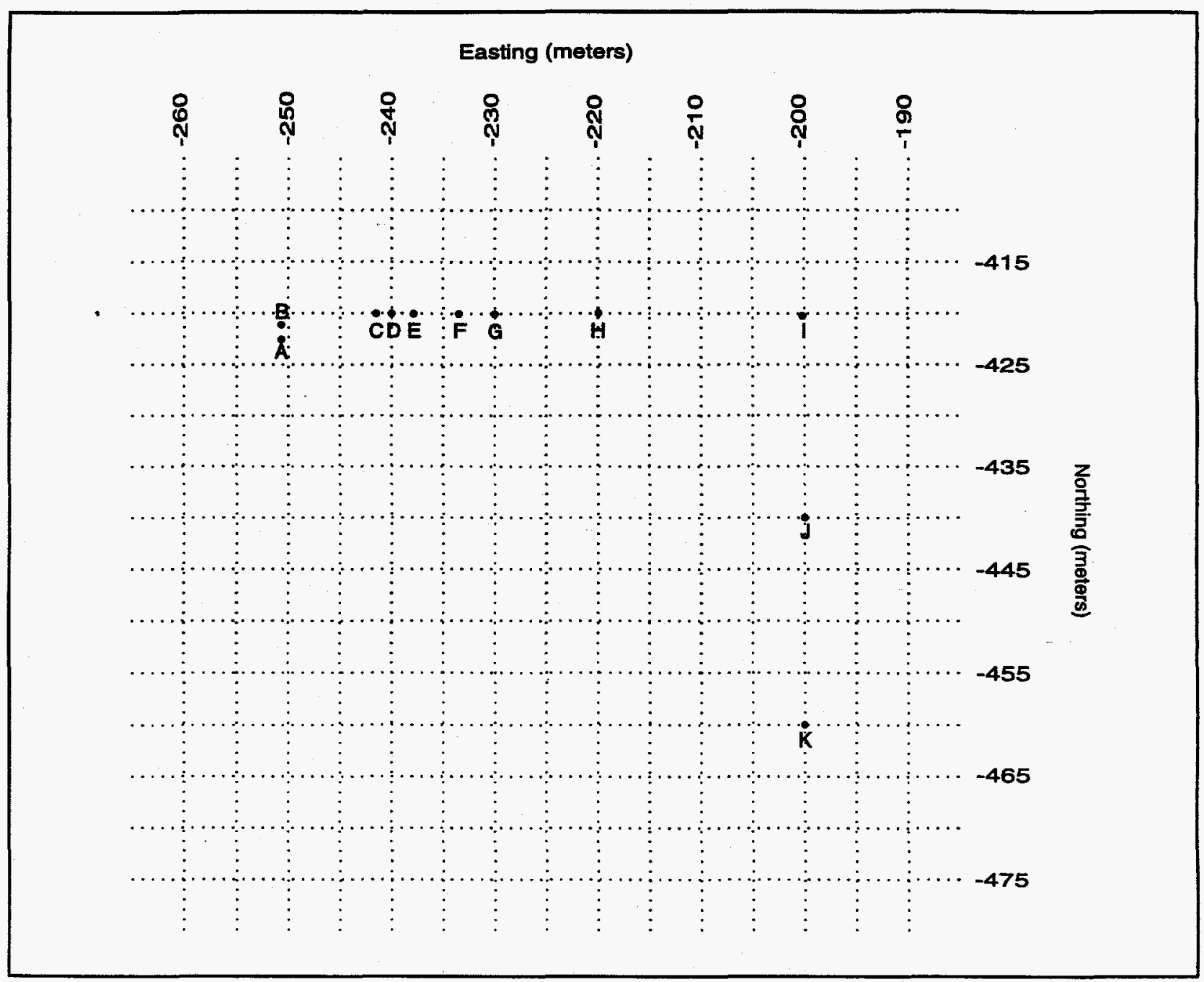

Figure A-6. Rabbit Valley GPER Area 6 


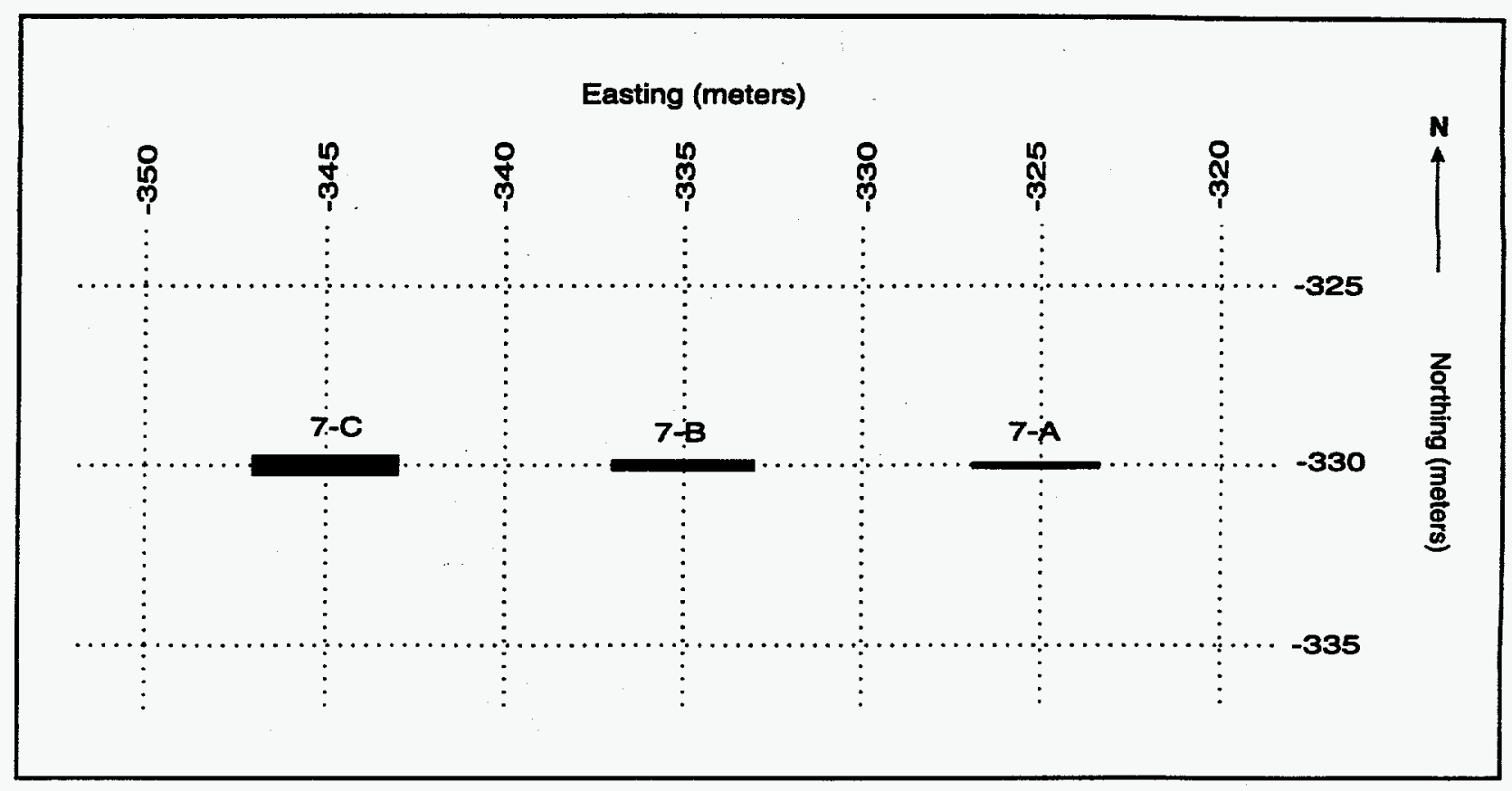

Figure A-7. Rabbit Valley GPER Area 7

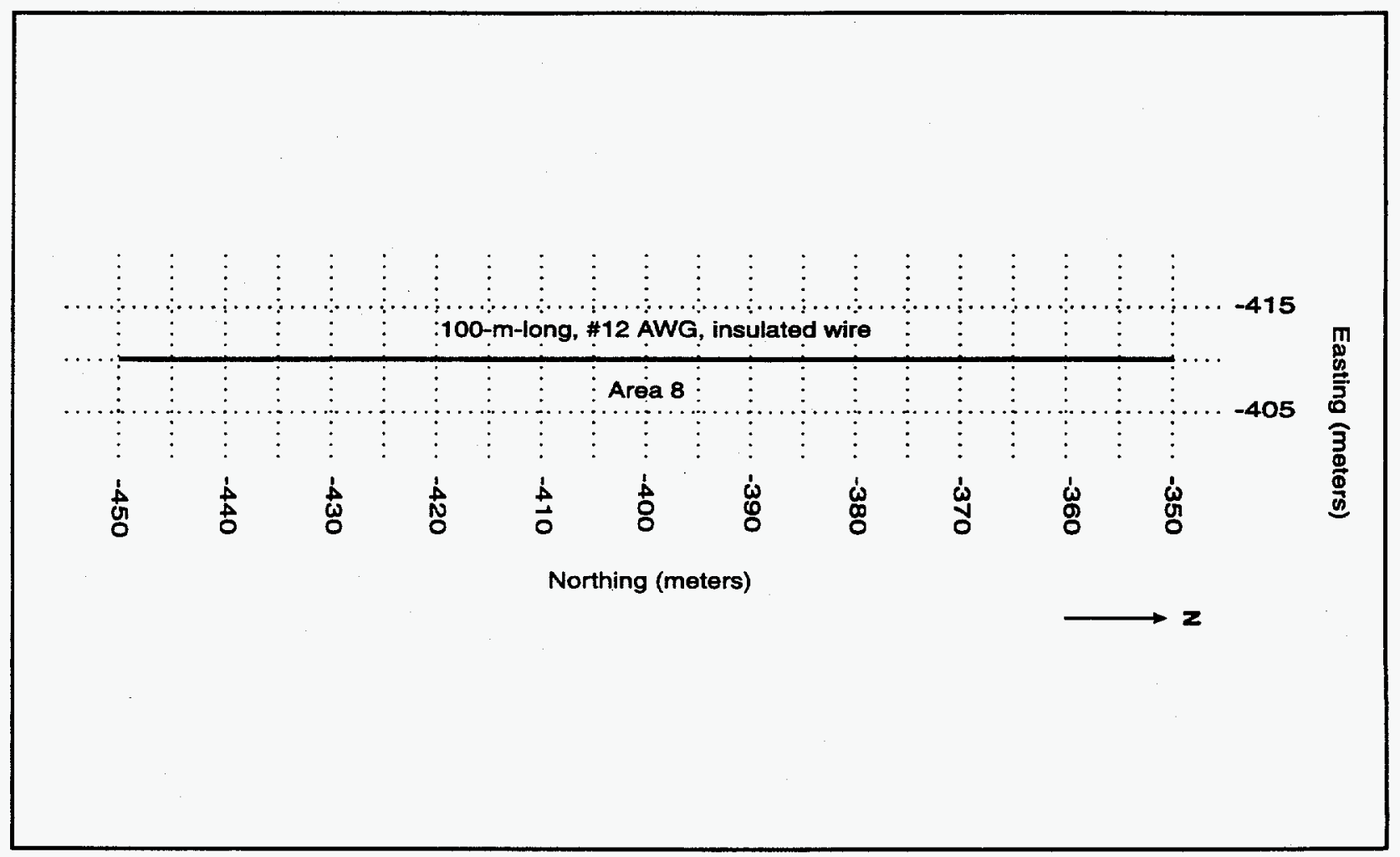

Figure A-8. Rabbit Valley GPER Area 8

$$
\text { A-9 }
$$




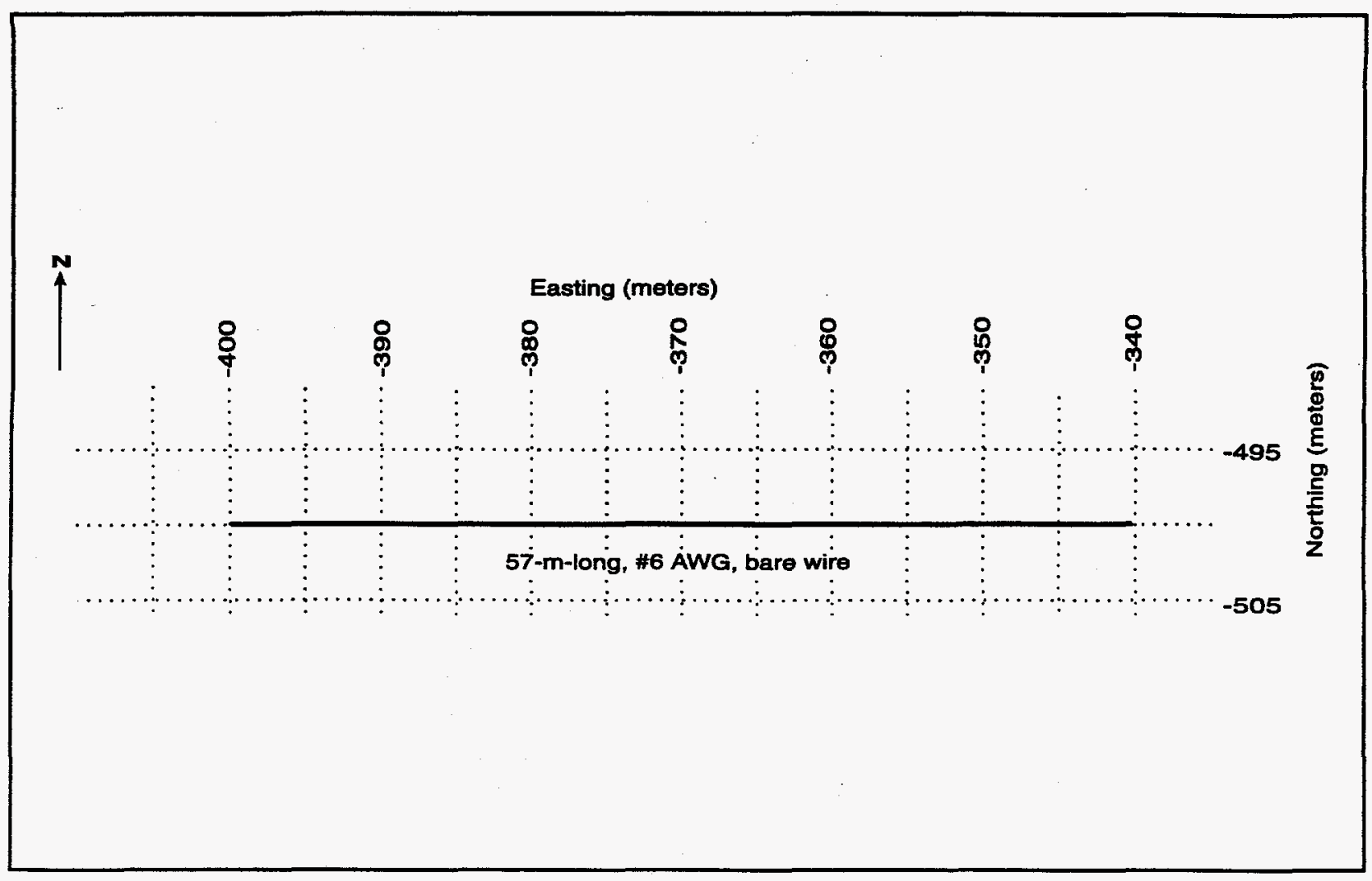

Figure A-9. Rabbit Valley GPER Area 9 


\section{Appendix B \\ Soil Sample Analysis Report}




\section{ANALYTICAL REPORT INDEX}

This report is the final data package for Requisition no. 12672 generated by the Petrology subsection of the Analytical Laboratory for a Program

Development and Management research project. It is the official record and requestors are responsible for proper record-keeping in accordance with project requirements.

This report was prepared as an account of work sponsored by an agency of the United States Government. Neither the United States Government nor any agency thereof, nor any of their employees, makes any warranty, expressed or implied, or assumes any legal liability or responsibility for the accuracy, completeness, or usefulness of any information, apparatus, product, or process disclosed in this report, or represents that its use would not infringe privately owned rights. Reference therein to any specific commercial product, process, or service by trade name, trademark, manufacturer, or otherwise, does not necessarily constitute or imply its endorsement, recommendation, or favoring by the United States Government or any agency thereof. The views and opinions of authors expressed herein do not necessarily state or reflect those of the United States Government or any agency thereof.

This report includes the following documents:

\section{Cover Page}

Analytical Report Index

Analytical Summary

Sample Index

Section 1

Analytical Results

Section 2

Loss-on-Drying Supporting Documentation

Section 3

X-ray Diffraction Supporting Documentation

Section 4

Sieve and Pipette Analysis Supporting Documentation

Section 5

Duplication Copy of Results Report

Section 6

Receiving Documentation 
ANALYTICAL SUMMARY

This report contains the results of seven samples received under Project No. 4RCMS2121, Requisition no. 12672 on May 26, 1994.

The sample was submitted by Jim Allen for loss on drying, grain size analysis, bulk- and clay-mineral analysis using $X$-ray diffraction.

RELEASE OF THE DATA CONTAINED IN THIS PACKAGE HAS BEEN AUTHORIZED BY THE LABORATORY MANAGER OR THE MANAGERS DESIGNER.

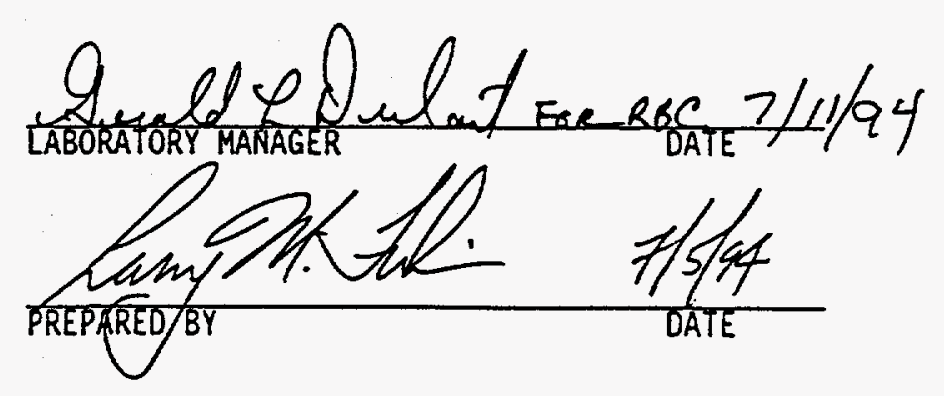

B-4 


\section{RESULTS}

LOSS ON DRYING (LOD)

REQUESTED BY: JIM ALLEN

PROJECT MO.: $\quad$ 4RCMS2121

DATE: JULY 5, 1994
REQUISITION NO.: 12672

SITE: RABBIT VALLEY

PROCEDURE: M2, REV 02

\begin{tabular}{ccc} 
Lab ID & $\begin{array}{c}\text { Sample } \\
\text { Number }\end{array}$ & $\begin{array}{c}\text { LOD } \\
\text { Wt. } \%\end{array}$ \\
\hline 219689 & NCE 918 & 5.6 \\
219690 & NCE 919 & 6.9 \\
219691 & NCE 920 & 4.4 \\
219692 & NCE 921 & 6.9 \\
219693 & NCE 922 & 5.7 \\
219694 & NCE 923 & 8.5 \\
219695 & NCE 924 & 5.2
\end{tabular}

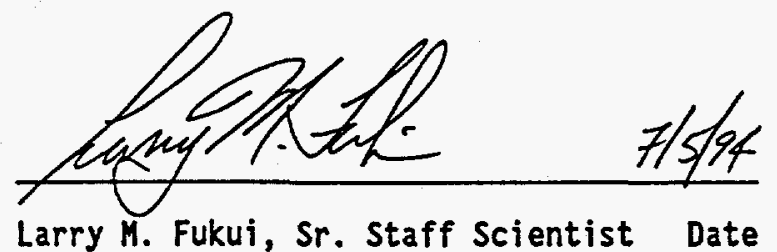




\section{RESULTS}

BULK X-RAY DIFFRACTION

REQUESTED BY: JIM ALLEN PROJECT NO.: $\quad$ 4RCMS2121 DATE: JULY 5, 1994
REQUISITION NO.: 12672

SITE: RABBIT VALLEY

PROCEDURE: XRD-02-83, REV 07

\begin{tabular}{|c|c|c|c|c|}
\hline $\begin{array}{l}\text { Sample } \\
\text { Number }\end{array}$ & $\begin{array}{l}\text { Mineral } \\
\text { Name }\end{array}$ & $\begin{array}{l}\text { Chemical } \\
\text { Formula }\end{array}$ & PDF Card* & Abundance \\
\hline \multirow[t]{2}{*}{ NCE 918} & $\begin{array}{l}\text { Quartz } \\
\text { Calcite } \\
\text { K-feldspar } \\
\text { Illite }\end{array}$ & $\begin{array}{l}\mathrm{SiO}_{2} \\
\mathrm{CaCO}_{3} \\
\mathrm{KAlS}_{3} \mathrm{O}_{8} \\
\left(\mathrm{~K}, \mathrm{H}_{3} \mathrm{O}\right)(\mathrm{Al}, \mathrm{Mg}, \mathrm{Fe})_{2}(\mathrm{Al},\end{array}$ & $\begin{array}{c}5-490 \\
5-586 \\
19-932 \\
{\left[(\mathrm{OH})_{2}, \mathrm{H}_{2} \mathrm{O}\right]} \\
26-91]\end{array}$ & $\begin{array}{l}\text { Dominant } \\
\text { Moderate } \\
\text { Minor } \\
\text { Trace }\end{array}$ \\
\hline & $\begin{array}{l}\text { Kaolinite } \\
\text { Plagioclase }\end{array}$ & $\begin{array}{l}\mathrm{Al}_{2} \mathrm{Si}_{2} \mathrm{O}_{3}(\mathrm{OH})_{8} \\
(\mathrm{Na}, \mathrm{Ca}) \mathrm{Al}\left(\mathrm{AI}, \mathrm{Si} / \mathrm{Si}_{2} \mathrm{O}_{8}\right.\end{array}$ & $\begin{array}{l}14-164 \\
10-393\end{array}$ & $\begin{array}{l}\text { Trace } \\
\text { Trace }\end{array}$ \\
\hline \multirow[t]{2}{*}{ NCE 919} & $\begin{array}{l}\text { Quartz } \\
\text { K-feldspar } \\
\text { Calcite } \\
\text { Illite }\end{array}$ & $\begin{array}{l}\mathrm{SiO}_{2} \\
\mathrm{KATS} \mathrm{S}_{3} \\
\mathrm{CaCO}_{3} \\
\left(\mathrm{~K}, \mathrm{H}_{3} \mathrm{O}\right)(\mathrm{Al}, \mathrm{Mg}, \mathrm{Fe})_{2}(\mathrm{Al},\end{array}$ & $\begin{array}{c}5-490 \\
19-932 \\
5-586 \\
{\left[(\mathrm{OH})_{2}, \mathrm{H}_{2} \mathrm{O}\right]}\end{array}$ & $\begin{array}{l}\text { Dominant } \\
\text { Minor } \\
\text { Minor }\end{array}$ \\
\hline & $\begin{array}{l}\text { Kaolinite } \\
\text { Plagioclase }\end{array}$ & $\begin{array}{l}\mathrm{Al}_{2} \mathrm{Si}_{2} \mathrm{O}_{5}(\mathrm{OH})_{4} \\
(\mathrm{Na}, \mathrm{Ca}) \mathrm{Al}(\mathrm{AI}, \mathrm{Si}) \mathrm{Si}_{2} \mathrm{O}_{3}\end{array}$ & $\begin{array}{l}14-164 \\
10-393\end{array}$ & $\begin{array}{l}\text { Trace } \\
\text { Trace } \\
\text { Trace }\end{array}$ \\
\hline \multirow[t]{2}{*}{ NCE 920} & $\begin{array}{l}\text { Quartz } \\
\text { Calcite } \\
\text { K-feldspar } \\
\text { Illite }\end{array}$ & $\begin{array}{l}\mathrm{SiO}_{2} \\
\mathrm{CaCO}_{3} \\
\mathrm{KAlSi}_{3} \mathrm{O}_{8} \\
\left(\mathrm{~K}, \mathrm{H}_{3} \mathrm{O}\right)(\mathrm{Al}, \mathrm{Mg}, \mathrm{Fe})_{2}(\mathrm{Al},\end{array}$ & $\begin{array}{c}5-490 \\
5-586 \\
19-932 \\
{\left[(\mathrm{OH})_{2}, \mathrm{H}_{2} \mathrm{O}\right]}\end{array}$ & $\begin{array}{l}\text { Dominant } \\
\text { Moderate } \\
\text { Minor }\end{array}$ \\
\hline & $\begin{array}{l}\text { Kaolinite } \\
\text { Plagioclase }\end{array}$ & $\begin{array}{l}\mathrm{Al}_{2} \mathrm{Si}_{2} \mathrm{O}_{5}(\mathrm{OH}) \\
(\mathrm{Na}, \mathrm{Ca}) \mathrm{Al}(\mathrm{Ai}, \mathrm{Si}) \mathrm{Si}_{2} \mathrm{O}_{\mathrm{a}}\end{array}$ & $\begin{array}{l}14-164 \\
10-393\end{array}$ & $\begin{array}{l}\text { Trace } \\
\text { Trace }\end{array}$ \\
\hline
\end{tabular}

* Standard pattern from the Joint Committee on Powder Diffraction Standards

Explanation of Semiquantitative terms

Dominant - Predominant mineral in $X$-ray pattern

Subdominant - 70 to $99 \%$ of intensity of dominant phase

Moderate - 30 to $70 \%$ of intensity of dominant phase

Minor $\quad-7$ to $30 \%$ of intensity of dominant phase

Trace $\quad-<7 \%$ of intensity of dominant phase

n.d. - Not detected

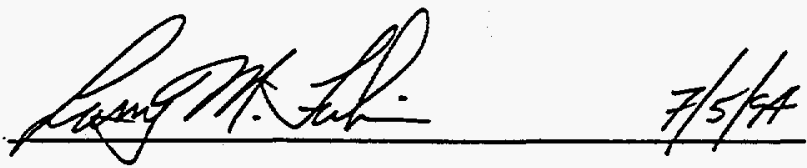

Larry M. Fukui, Sr. Staff Scientist Date 


\section{RESULTS}

\section{BULK X-RAY DIFFRACTION}

REQUESTED BY: JIM ALLEN PROJECT NO.: $\quad$ 4RCMS2121 DATE: JULY 5, 1994
REQUISITION NO.: 12672

SITE: RABBIT VALLEY

PROCEDURE: XRD-02-83, REV 07

\begin{tabular}{|c|c|c|c|c|}
\hline $\begin{array}{l}\text { Sample } \\
\text { Number }\end{array}$ & $\begin{array}{l}\text { Mineral } \\
\text { Name }\end{array}$ & $\begin{array}{l}\text { Chemical } \\
\text { Formula }\end{array}$ & PDF Card* & Abundance \\
\hline \multirow[t]{2}{*}{ NCE 921} & $\begin{array}{l}\text { Quartz } \\
\text { Calcite } \\
\text { K-feldspar } \\
\text { Plagioclase } \\
\text { Smectite }\end{array}$ & $\begin{array}{l}\mathrm{SiO}_{2} \\
\mathrm{CaCO}_{3} \\
\mathrm{KAlSi}_{3} \mathrm{O}_{8} \\
(\mathrm{Na}, \mathrm{Ca}) \mathrm{Al}(\mathrm{Al}, \mathrm{Si}) \mathrm{Si}_{2} \mathrm{O}_{8} \\
(\mathrm{Na}, \mathrm{Ca})_{0.3}(\mathrm{Al}, \mathrm{Mg})_{2} \mathrm{Si}_{4} \mathrm{O}_{30} \cdot \mathrm{nH}_{2} \mathrm{O}\end{array}$ & $\begin{array}{r}5-490 \\
5-586 \\
19-932 \\
10-393\end{array}$ & $\begin{array}{l}\text { Dominant } \\
\text { Subdominant } \\
\text { Minor } \\
\text { Trace }\end{array}$ \\
\hline & Illite & $(\mathrm{K}, \mathrm{H}, \mathrm{O})(\mathrm{Al}, \mathrm{Mg}, \mathrm{Fe})_{2}(\mathrm{Al}, \mathrm{Si})_{2} \mathrm{O}_{30}$ & $\begin{array}{c}13-259 \\
{\left[(\mathrm{OH})_{2}, \mathrm{H}_{2} \mathrm{O}\right]} \\
26-911\end{array}$ & $\begin{array}{l}\text { Minor } \\
\text { Trace }\end{array}$ \\
\hline \multirow[t]{2}{*}{ NCE 922} & $\begin{array}{l}\text { Quartz } \\
\text { Calcite } \\
\text { K-feldspar } \\
\text { Plagiociase } \\
\text { Illite }\end{array}$ & $\begin{array}{l}\mathrm{SiO}_{2} \\
\mathrm{CaCO}_{3} \\
\mathrm{KAISi}_{3} \mathrm{O}_{3} \\
(\mathrm{Na}, \mathrm{Ca}) \mathrm{Al}(\mathrm{Al}, \mathrm{Si}) \mathrm{Si}_{2} \mathrm{O}_{8} \\
(\mathrm{~K}, \mathrm{H}, \mathrm{O})(\mathrm{Al}, \mathrm{Mg}, \mathrm{Fe})_{2}(\mathrm{AI}, \mathrm{Si}), \mathrm{O}_{20}\end{array}$ & $\begin{array}{c}5-490 \\
5-586 \\
19-932 \\
10-393 \\
{\left[(\mathrm{OH})_{2}, \mathrm{H}_{2} \mathrm{O}\right]} \\
26-911\end{array}$ & $\begin{array}{l}\text { Dominant } \\
\text { Minor } \\
\text { Trace } \\
\text { Trace } \\
\text { Trace }\end{array}$ \\
\hline & Kaolinite & $\mathrm{Al}_{2} \mathrm{Si}_{2} \mathrm{O}_{5}(\mathrm{OH})_{4}$ & $14-164$ & Trace \\
\hline \multirow[t]{2}{*}{ NCE 923} & $\begin{array}{l}\text { Quartz } \\
\text { Calcite } \\
\text { Smectite }\end{array}$ & $\begin{array}{l}\mathrm{SiO}_{2} \\
\mathrm{CaCO}_{3} \\
(\mathrm{Na}, \mathrm{Ca})_{0.3}(\mathrm{Al}, \mathrm{Mg})_{2} \mathrm{Si}_{4} \mathrm{O}_{20} \cdot \mathrm{nH}_{2} \mathrm{O}\end{array}$ & $\begin{array}{l}5-490 \\
5-586\end{array}$ & $\begin{array}{l}\text { Dominant } \\
\text { Subdominant }\end{array}$ \\
\hline & Illite & $\left(\mathrm{K}, \mathrm{H}_{3} \mathrm{O}\right)(\mathrm{Al}, \mathrm{Mg}, \mathrm{Fe})_{2}(\mathrm{Al}, \mathrm{Si})_{4}$ & $\begin{array}{c}13-259 \\
{\left[\begin{array}{l}\left.(\mathrm{OH})_{2}, \mathrm{H}_{2} \mathrm{O}\right] \\
26-911\end{array}\right.}\end{array}$ & Trace \\
\hline
\end{tabular}

* Standard pattern from the Joint Committee on Powder Diffraction Standards Explanation of Semiquantitative terms

Dominant - Predominant mineral in X-ray pattern

Subdominant - 70 to $99 \%$ of intensity of dominant phase

Moderate - 30 to $70 \%$ of intensity of dominant phase

Minor $\quad-7$ to $30 \%$ of intensity of dominant phase

Trace $\quad-<7 \%$ of intensity of dominant phase

n.d. - Not detected

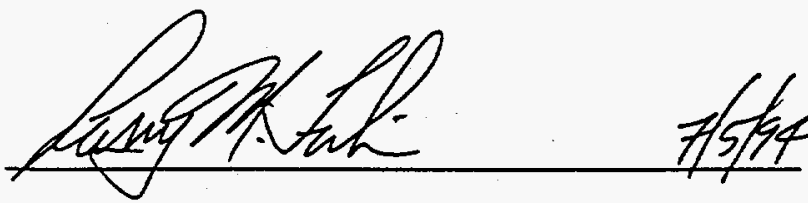

Larry M. Fukui, Sr. Staff Scientist Date 


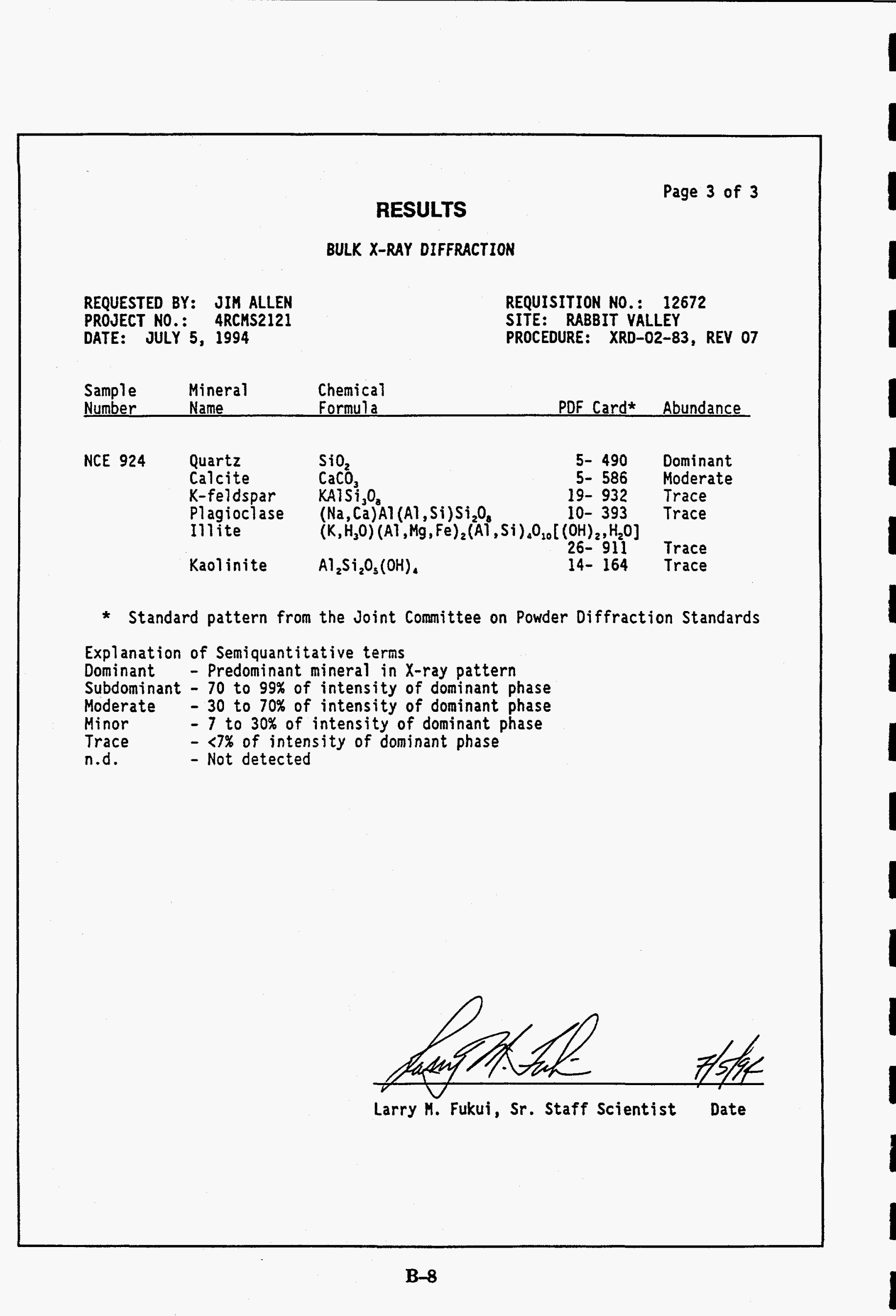




\section{RESULTS}

\section{CLAY MINERAL ANALYSIS}

REQUESTED BY: JIM ALLEN

PROJECT NO.: $\quad$ 4RCHS2121

DATE: JULY 5, 1994
REQUISITION NO.: 12672

SITE: RABBIT VALLEY

PROCEDURE: CMA-05-92, REV. OO

\section{Sample NCE 918}

Illite (Dominant)

Chemical formula: $\left(\mathrm{K}, \mathrm{H}_{3} \mathrm{O}\right)(\mathrm{Al}, \mathrm{Mg}, \mathrm{Fe})_{2}(\mathrm{Al}, \mathrm{Si})_{4} \mathrm{O}_{30}\left[(\mathrm{OH})_{2}, \mathrm{H}_{2} \mathrm{O}\right]$

Randomly interstratified illite/smectite (Subdominant)

Chemical formula: $\left.\left(\mathrm{K}, \mathrm{H}_{3} \mathrm{O}\right)(\mathrm{Al}, \mathrm{Mg}, \mathrm{Fe})_{2}(\mathrm{~A}], \mathrm{Si}\right)_{4} \mathrm{O}_{20}\left[(\mathrm{OH})_{2}, \mathrm{H}_{2} \mathrm{O}\right] /$

$$
(\mathrm{Na}, \mathrm{Ca})_{0.2}(\mathrm{Al}, \mathrm{Mg})_{2} \mathrm{Si}_{4} \mathrm{O}_{20} \cdot \mathrm{nH}_{2} \mathrm{O}
$$

Kaolinite (Moderate)

Chemical formula: $\mathrm{Al}_{2} \mathrm{Si}_{2} \mathrm{O}_{5}(\mathrm{OH})_{4}$

Chlorite (Minor)

Chenical formula: (Mg, $\mathrm{Fe})_{5} \mathrm{Al}(\mathrm{Si}, \mathrm{Al})_{20}(\mathrm{OH})_{8}$

Sample NCE 919

Illite (Dominant)

Chemica) formula: $\left.\left(\mathrm{K}, \mathrm{H}_{3} \mathrm{O}\right)(\mathrm{Al}, \mathrm{Mg}, \mathrm{Fe})_{2}(\mathrm{Al}, \mathrm{Si})_{4} \mathrm{O}_{20}[\mathrm{OH})_{2}, \mathrm{H}_{2} \mathrm{O}\right]$

Randomly interstratified $i l l i t e / s m e c t i t e$ (Subdominant)

Chemical formula: ( $\left.\mathrm{K}, \mathrm{H}_{3} \mathrm{O}\right)(\mathrm{Al}, \mathrm{Mg}, \mathrm{Fe})_{2}(\mathrm{Al}, \mathrm{Si})_{4} \mathrm{O}_{10}\left[(\mathrm{OH})_{2}, \mathrm{H}_{2} \mathrm{O}\right] /$

$$
(\mathrm{Na}, \mathrm{Ca})_{0.3}(\mathrm{AT}, \mathrm{Mg})_{2} \mathrm{Si}_{4} \mathrm{O}_{10} \cdot \mathrm{nH}_{2} \mathrm{O}
$$

Kaolinite (Moderate)

Chemical formula: $\mathrm{Al}_{2} \mathrm{Si}_{2} \mathrm{O}_{5}(\mathrm{OH})_{4}$

Chlorite (Minor)

Chemical formula: (Mg, $\mathrm{Fe})_{5} \mathrm{Al}(\mathrm{Si}, \mathrm{Al})_{30}(\mathrm{OH})_{3}$

Exolanation of Semiquantitative terms

Dominant - Predominant mineral in $x$-ray pattern

Subdominant - 70 to $99 \%$ of intensity of dominant phase

Moderate - 30 to $70 \%$ of intensity of dominant phase

Minor $\quad-7$ to $30 \%$ of intensity of dominant phase

Trace $\quad-\quad<7 \%$ of intensity of dominant phase

n.d.

- Not detected

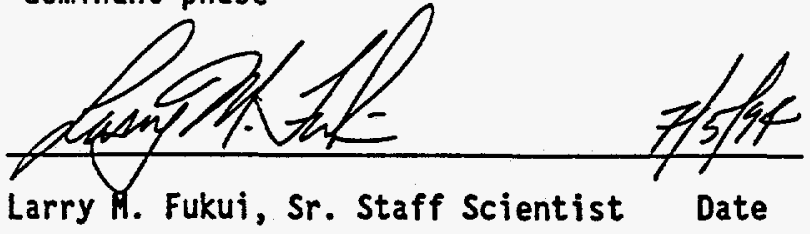




\section{RESULTS}

\section{CLAY MINERAL ANALYSIS}

REQUESTED BY: JIM ALLEN

PROJECT NO.: $\quad$ 4RCMS2121

DATE: JULY 5, 1994
REQUISITION NO.: 12672

SITE: RABBIT VALLEY

PROCEDURE: CMA-05-92, REV. 00

Sample NCE 920

Randomly interstratified illite/smectite (Dominant)

. Chemical formula: ( $\left.\mathrm{K}, \mathrm{H}_{3} \mathrm{O}\right)(\mathrm{Al}, \mathrm{Mg}, \mathrm{Fe})_{2}(\mathrm{Al}, \mathrm{Si})_{2} \mathrm{O}_{20}\left[(\mathrm{OH})_{2}, \mathrm{H}_{2} \mathrm{O}\right] /$

$$
(\mathrm{Na}, \mathrm{Ca})_{0.3}(\mathrm{AT}, \mathrm{Mg})_{2} \mathrm{Si}_{4} \mathrm{O}_{20} \cdot \mathrm{nH}_{2} \mathrm{O}
$$

- Illite (Subdominant)

Chemical formula: $\left(\mathrm{K}, \mathrm{H}_{3} \mathrm{O}\right)(\mathrm{Al}, \mathrm{Mg}, \mathrm{Fe})_{2}(\mathrm{AT}, \mathrm{Si})_{4} \mathrm{O}_{30}\left[(\mathrm{OH})_{2}, \mathrm{H}_{2} \mathrm{O}\right]$

Kaolinite (Moderate)

Chemical formula: $\mathrm{Al}_{2} \mathrm{Si}_{2} \mathrm{O}_{5}(\mathrm{OH})_{4}$

Chlorite (Trace)

Chemical formula: $(\mathrm{Mg}, \mathrm{Fe})_{5} \mathrm{Al}(\mathrm{Si}, \mathrm{Al})_{10}(\mathrm{OH})_{8}$

Sample NCE 921

Smectite (Dominant)

Chemical formula: (Na, Ca) $)_{0.3}(\mathrm{Al}, \mathrm{Mg})_{2} \mathrm{Si}_{4} \mathrm{O}_{20} \cdot \mathrm{nH}_{2} \mathrm{O}$

Illite (Moderate)

Chemical formula: $\left(\mathrm{K}, \mathrm{H}_{3} \mathrm{O}\right)(\mathrm{Al}, \mathrm{Mg}, \mathrm{Fe})_{2}(\mathrm{Al}, \mathrm{Si})_{4} \mathrm{O}_{30}\left[(\mathrm{OH})_{2}, \mathrm{H}_{2} \mathrm{O}\right]$

Kaolinite (Moderate)

Chemical formula: $\mathrm{Al}_{2} \mathrm{Si}_{2} \mathrm{O}_{3}(\mathrm{OH})_{4}$

Explanation of Semiquantitative terms

Dominant - Predominant mineral in X-ray pattern

Subdominant - 70 to $99 \%$ of intensity of dominant phase

Moderate - 30 to $70 \%$ of intensity of dominant phase

Minor $\quad-7$ to $30 \%$ of intensity of dominant phase

Trace $\quad-<7 \%$ of intensity of dominant phase

n.d. - Not detected

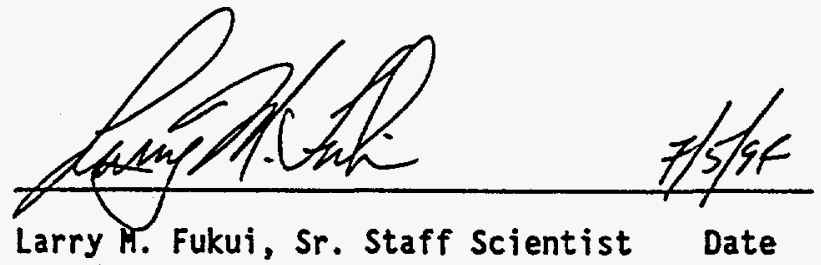




\section{RESULTS}

CLAY MINERAL ANALYSIS

REQUESTED BY: JIM ALLEN

PROJECT NO.: $\quad$ 4RCMS2121

DATE: JULY 5, 1994
REQUISITION NO.: 12672

SITE: RABBIT VALLEY

PROCEDURE: CMA-05-92, REV. 00

\section{Sample NCE 922}

Randomly interstratified illite/smectite (Dominant)

Chemical formula: $\left(\mathrm{K}, \mathrm{H}_{3} \mathrm{O}\right)(\mathrm{Al}, \mathrm{Mg}, \mathrm{Fe})_{2}(\mathrm{Al}, \mathrm{Si})_{4} \mathrm{O}_{10}\left[(\mathrm{OH})_{2}, \mathrm{H}_{2} \mathrm{O}\right] /$

$(\mathrm{Na}, \mathrm{Ca})_{0.3}(\mathrm{AT}, \mathrm{Mg})_{2} \mathrm{Si}_{4} \mathrm{O}_{10} \cdot \mathrm{nH}_{2} \mathrm{O}$

Illite (Subdominant)

Chemical formula: $\left(\mathrm{K}, \mathrm{H}_{3} \mathrm{O}\right)(\mathrm{Al}, \mathrm{Mg}, \mathrm{Fe})_{2}(\mathrm{Al}, \mathrm{Si})_{6} \mathrm{O}_{10}\left[(\mathrm{OH})_{2}, \mathrm{H}_{2} \mathrm{O}\right]$

Kaolinite (Moderate)

Chemical formula: $\mathrm{Al}_{2} \mathrm{Si}_{2} \mathrm{O}_{5}(\mathrm{OH})$.

Chlorite (Trace)

Chemical formula: (Mg, Fe $)_{3} \mathrm{Al}(\mathrm{Si}, \mathrm{Al})_{10}(\mathrm{OH})_{8}$

Sample NCE 923

Smectite (Dominant)

Chemical formula: (Na, Ca $)_{0.3}(\mathrm{Al}, \mathrm{Mg})_{2} \mathrm{Si}_{4} \mathrm{O}_{10} \cdot \mathrm{nH}_{2} \mathrm{O}$

Illite (Moderate)

Chemical formula: $\left(\mathrm{K}, \mathrm{H}_{3} \mathrm{O}\right)(\mathrm{Al}, \mathrm{Mg}, \mathrm{Fe})_{2}(\mathrm{Al}, \mathrm{Si})_{4} \mathrm{O}_{20}\left[(\mathrm{OH})_{2}, \mathrm{H}_{2} \mathrm{O}\right]$

Kaolinite (Moderate)

Chemical formula: $\mathrm{Al}_{2} \mathrm{Si}_{2} \mathrm{O}_{5}(\mathrm{OH})_{4}$

Explanation of Semiquantitative terms

Dominant - Predominant mineral in $X$-ray pattern

Subdominant - 70 to $99 \%$ of intensity of dominant phase

Moderate - 30 to $70 \%$ of intensity of dominant phase

Minor $\quad-7$ to $30 \%$ of intensity of dominant phase

Trace $\quad-<7 \%$ of intensity of dominant phase

n.d. - Not detected

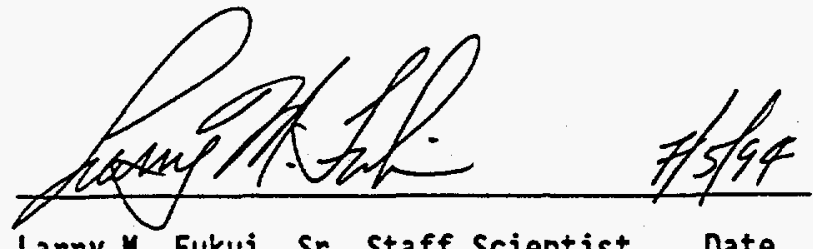

Larry M. Fukui, Sr. Staff Scientist Date 


\section{RESULTS}

\section{CLAY MINERAL ANALYSIS}

REQUESTED BY: JIM ALLEN

PROJECT NO.: ARCMS2121

DATE: JULY 5, 1994
REQUISITION NO.: 12672

SITE: RABBIT VALLEY

PROCEDURE: CMA-05-92, REV. 00

Sample NCE 924

Illite (Dominant)

Chemical formula: $\left(\mathrm{K}, \mathrm{H}_{3} \mathrm{O}\right)(\mathrm{Al}, \mathrm{Mg}, \mathrm{Fe})_{2}(\mathrm{Al}, \mathrm{Si})_{4} \mathrm{O}_{20}\left[(\mathrm{OH})_{2}, \mathrm{H}_{2} \mathrm{O}\right]$

Randomly interstratified $i l l i t e /$ smectite (Subdominant)

Chemical formula: ( $\left.\mathrm{K}, \mathrm{H}_{3} \mathrm{O}\right)(\mathrm{AT}, \mathrm{Mg}, \mathrm{Fe})_{2}(\mathrm{AT}, \mathrm{Si})_{4} \mathrm{O}_{20}\left[(\mathrm{OH})_{2}, \mathrm{H}_{2} \mathrm{O}\right] /$

$(\mathrm{Na}, \mathrm{Ca})_{0.3}(\mathrm{AT}, \mathrm{Mg})_{2} \mathrm{Si}_{4} \mathrm{O}_{30} \cdot \mathrm{nH}_{2} \mathrm{O}$

Kaolinite (Moderate)

Chemical formula: $\mathrm{Al}_{2} \mathrm{Si}_{2} \mathrm{O}_{5}(\mathrm{OH})_{4}$

Chlorite (Minor)

Chemical formula: $(\mathrm{Mg}, \mathrm{Fe})_{5} \mathrm{Al}(\mathrm{Si}, \mathrm{Al})_{10}(\mathrm{OH})_{0}$.

Explanation of Semiquantitative terms

Dominant - Predominant mineral in $x$-ray pattern

Subdominant - 70 to $99 \%$ of intensity of dominant phase

Moderate - 30 to $70 \%$ of intensity of dominant phase

Minor $\quad-7$ to $30 \%$ of intensity of dominant phase

Trace $\quad-<7 \%$ of intensity of dominant phase

n.d. $\quad$ - Not detected

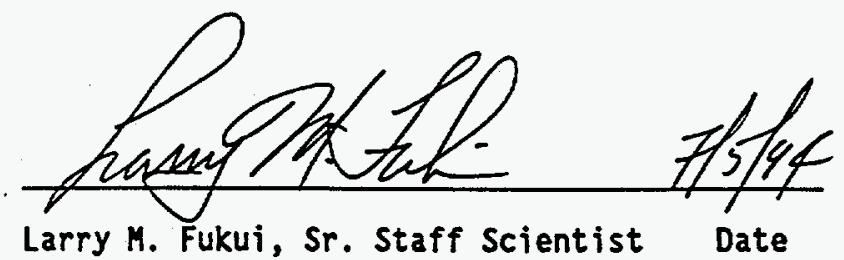




\section{GRAIN SIZE RESULTS}

SAMPLE NCE 918

REQUESTED BY: JIM ALLEN

PROJECT NO.: ARCMS2121

DATE: JULY 5,1994
REQUISITION NO.: 12672

SITE: RABBIT VALLEY

PROCEDURE: SA-02-83, REV. 05

Sieve Analysis

\begin{tabular}{cc}
$\Phi$ & Mesh \\
\hline 0 & 18 \\
1 & 35 \\
2 & 60 \\
3 & 120 \\
4 & 230 \\
5 & PAN
\end{tabular}

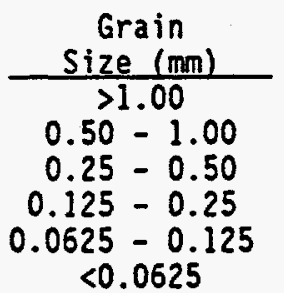

\begin{tabular}{cc}
$\begin{array}{c}\text { Weight } \\
\text { (grams) }\end{array}$ & $\begin{array}{r}\text { Weight } \\
\text { Percent }\end{array}$ \\
\hline 15.77 & 19.44 \\
6.13 & 7.55 \\
5.96 & 7.35 \\
14.02 & 17.28 \\
21.28 & 26.63 \\
17.98 & 22.16
\end{tabular}

Data points from graph of cumulative percent vs grain size in phi ( $\phi)$

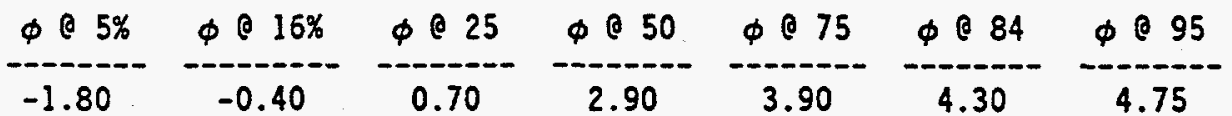

Statistical Parameters of Grain Size

Graphic Mean ( $\left.\mathrm{Mz}_{2}\right)$ Fine sand

Inclusive Graphic Standard Deviation $\left(\mathrm{O}_{1}\right)=2.17 \phi=0.22 \mathrm{~mm}$ Very poorly sorted

Inclusive Graphic Skewness (Skl) Strongly coarse skewed

Graphic Kurtosis (KG) Platykurtic
$=2.27 \phi=0.21 \mathrm{~mm}$

$=-0.42$

$=0.84$

Pipette Analysis

$$
\begin{array}{cr}
\text { Grain } & \begin{array}{r}
\text { Weight } \\
\text { Size (mm) }
\end{array} \\
\hline 0.0020-0.0625(\text { silt }) & \frac{13.68}{8.68} \\
<0.0020 \text { (clay) } & 8.48 \\
\text { Total* } & 22.16
\end{array}
$$

* Pan fraction in sieve analysis, above.

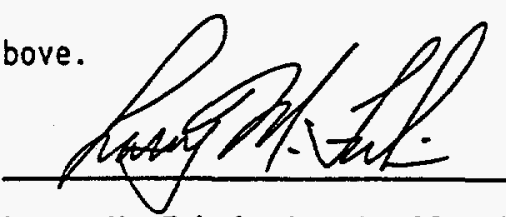

Larry M. Fukui, Sr. Staff Scientist 


\section{GRAIN SIZE RESULTS}

Page 2 of 7

SAMPLE NCE 919

REQUESTED BY: JIM ALLEN

PROJECT NO.: ARCMS2121

DATE: JULY 5, 1994
REQUISITION NO.: 12672

SITE: RABBIT YALLEY

PROCEDURE: SA-02-83, REV. 05

\section{Sieve Analysis}

\begin{tabular}{ccccc}
$\phi$ & Mesh & $\begin{array}{c}\text { Grain } \\
\text { Size (mm) }\end{array}$ & $\begin{array}{c}\text { Weight } \\
\text { (arams) }\end{array}$ & $\begin{array}{r}\text { Weight } \\
\text { Percent }\end{array}$ \\
\cline { 2 - 3 } 0 & $\frac{18}{18}$ & 0.00 & 9.36 & 9.04 \\
1 & 35 & $0.50-1.00$ & 8.27 & 7.99 \\
2 & 60 & $0.25-0.50$ & 12.19 & 11.77 \\
3 & 120 & $0.125-0.25$ & 24.52 & 23.68 \\
4 & 230 & $0.0625-0.125$ & 29.92 & 28.89 \\
5 & PAN & $<0.0625$ & 19.29 & 18.63
\end{tabular}

Data points from graph of cumulative percent vs grain size in phi ( $\phi)$

\begin{tabular}{|c|c|c|c|c|c|c|}
\hline$\phi 5 \%$ & $\phi \odot 16 \%$ & $\phi \odot 25$ & $\phi 50$ & $\phi 75$ & $\phi \odot 84$ & $\phi \bigcirc 95$ \\
\hline-0.70 & 0.90 & 1.80 & 2.90 & 3.75 & 4.10 & 4.70 \\
\hline
\end{tabular}

Statistical Parameters of Grain Size

Graphic Mean (Mz)

$=2.63 \phi=0.16 \mathrm{~mm}$

Fine sand

Inclusive Graphic Standard Deviation $\left(O_{1}\right)=1.62 \phi=0.32 \mathrm{~mm}$ Poorly sorted

Inclusive Graphic Skewness (SkI) Coarse skewed

Graphic Kurtos is (KG) Leptofurtic

$=-0.29$

$=1.13$

Pipette Analysis

\begin{tabular}{cr} 
Grain & $\begin{array}{c}\text { Weight } \\
\text { Size (mm) }\end{array}$ \\
\hline $0.0020-0.0625$ (silt) & $\frac{12.67}{12.67}$ \\
$<0.0020$ (clay) & 5.96 \\
Total* & 18.63
\end{tabular}

* Pan fraction in sieve analysis, above.

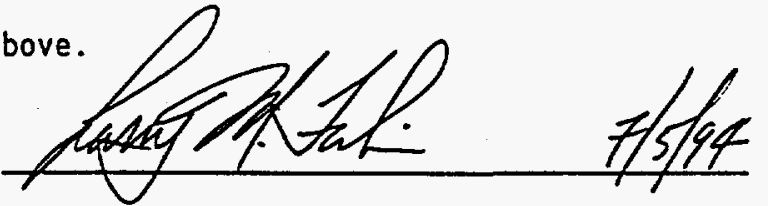

Larry M. Fukui, Sr. Staff Scientist Date 


\section{GRAIN SIZE RESULTS}

Page 3 of 7

\section{SAMPLE NCE 920}

REQUESTED BY: JIM ALLEN

PROJECT NO.: ARCKS2121

DATE: JULY 5, 1994
REQUISITION NO.: 12672

SITE: RABBIT YALLEY

PROCEDURE: SA-02-83, REY. 05

\section{$\underline{\text { Sieve Analysis }}$}

\begin{tabular}{ccccc}
$\Phi$ & Mesh & $\begin{array}{c}\text { Grain } \\
\text { Size }(\mathrm{mm})\end{array}$ & $\begin{array}{c}\text { Weight } \\
\text { (grams) }\end{array}$ & $\begin{array}{c}\text { Weight } \\
\text { Percent }\end{array}$ \\
\cline { 2 - 3 } & $\frac{>1.00}{18}$ & $\frac{15.56}{12.91}$ & 11.22 \\
1 & 35 & $0.50-1.00$ & 13.52 & 11.22 \\
2 & 60 & $0.25-0.50$ & 18.94 & 15.72 \\
3 & 120 & $0.125-0.25$ & 23.59 & 19.58 \\
4 & 230 & $0.0625-0.125$ & 31.69 & 26.30 \\
5 & PAN & $<0.0625$ & 17.20 & 14.27
\end{tabular}

Data points from graph of cumulative percent vs grain size in phi $(\phi)$

\begin{tabular}{|c|c|c|c|c|c|c|}
\hline $5 \%$ & $\phi 16 \%$ & $\phi 25$ & $\phi \odot 50$ & $\phi \odot 75$ & $\phi \odot 84$ & $\phi \odot 95$ \\
\hline-0.80 & 0.30 & 1.00 & 2.65 & 3.55 & 3.90 & 4.60 \\
\hline
\end{tabular}

Statistical Parameters of Grain Size

Graphic Mean ( $M z)$ Fine sand

Inclusive Graphic Standard Deviation $\left(O_{1}\right)=1.72 \phi=0.30 \mathrm{~mm}$ Poorly Sorted

Inclusive Graphic Skewness (Skı) Coarse skewed

Graphic Kurtosis $\left(K_{G}\right)$ Platykurtic
$=2.28 \phi=0.20 \mathrm{~mm}$

$=-0.29$

$=0.87$

\section{Pipette Analysis}

Grain

Size (mm)

$0.0020-0.0625$ (silt) $<0.0020$ (clay)

Total*

* Pan fraction in sieve analysis, above.

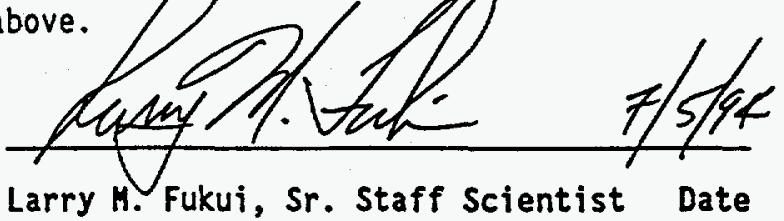




\section{GRAIN SIZE RESULTS}

\section{SAMPLE NCE 921}

REQUESTED BY: JIM ALLEN

PROJECT NO.: $\quad$ 4RCMS2121

DATE: JULY 5, 1994
REQUISITION NO.: 12672

SITE: RABBIT VALLEY

PROCEDURE: SA-02-83, REV. 05

Sieve Analysis

\begin{tabular}{|c|c|c|c|c|}
\hline & $\begin{array}{r}\frac{\text { Mesh }}{18} \\
35 \\
60 \\
120 \\
230 \\
\text { PAN }\end{array}$ & $\begin{array}{c}\text { Grain } \\
\text { Size (mm) } \\
>1.00 \\
0.50-1.00 \\
0.25-0.50 \\
0.125-0.25 \\
0.0625=0.125 \\
<0.0625\end{array}$ & $\begin{array}{c}\text { Weight } \\
\text { (grams) } \\
43.26 \\
9.21 \\
4.67 \\
5.17 \\
6.18 \\
10.42\end{array}$ & $\begin{array}{r}\begin{array}{r}\text { Weight } \\
\text { Percent }\end{array} \\
54.82 \\
11.67 \\
5.92 \\
6.55 \\
7.83 \\
13.20\end{array}$ \\
\hline
\end{tabular}

Data points from graph of cumulative percent vs grain size in phi ( $\phi)$

\begin{tabular}{|c|c|c|c|c|c|c|}
\hline $5 \%$ & $\phi 16 \%$ & $\phi 25$ & $\phi 50$ & $\phi 75$ & $\phi$ (อ 84 & $\phi 95$ \\
\hline-3.80 & -3.00 & -2.30 & -0.40 & 2.30 & 3.70 & 4.60 \\
\hline
\end{tabular}

Statistical Parameters of Grain Size

Graphic Mean (Mz) Medium sand

Inclusive Graphic Standard Deviation $\left(0_{1}\right)=2.95 \phi=0.13 \mathrm{~mm}$ Very poorly sorted

Inclusive Graphic Skewness (SkI)

Fine skewed

Graphic Kurtosis $\left\langle K_{G}\right\rangle$

Platykurtic
$=0.10 \phi=0.46 \mathrm{~mm}$

$=0.21$

$=0.75$

\section{Pipette Analysis}

\begin{tabular}{|c|c|}
\hline $\begin{array}{l}\text { Grain } \\
\text { Size (mm) }\end{array}$ & $\begin{array}{l}\text { Weight } \\
\text { Percent }\end{array}$ \\
\hline $\begin{array}{l}0.0020-0.0625(\mathrm{silt}) \\
<0.0020(\mathrm{clay}) \\
\text { Total* }\end{array}$ & $\begin{array}{r}6.81 \\
6.39 \\
13.20\end{array}$ \\
\hline
\end{tabular}

* Pan fraction in sieve analysis, above.

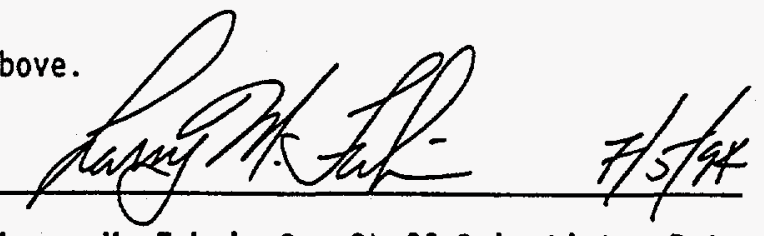

Larry M. Fukui, Sr. Staff Scientist Date 


\section{GRAIN SIZE RESULTS}

\section{SAMPLE NCE 922}

REQUESTED BY: JIM ALLEN

PROJECT NO.: 4RCNS2121

DATE: JULY 5, 1994
REQUISITION NO.: 12672

SITE: RABBIT VALLEY

PROCEDURE: SA-02-83, REY. 05

Sieve Analysis

\begin{tabular}{ccccr}
$\phi$ & Mesh & $\begin{array}{c}\text { Grain } \\
\text { Size (mm) }\end{array}$ & $\begin{array}{c}\text { Weight } \\
\text { (arams) }\end{array}$ & $\begin{array}{r}\text { Weight } \\
\text { Percent }\end{array}$ \\
\cline { 2 - 3 } & $\frac{>1.00}{18}$ & & 7.67 & 9.02 \\
1 & 35 & $0.50-1.00$ & 5.94 & 6.99 \\
2 & 60 & $0.25-0.50$ & 9.63 & 11.33 \\
3 & 120 & $0.125-0.25$ & 19.39 & 22.81 \\
4 & 230 & $0.0625-0.125$ & 23.04 & 27.11 \\
5 & PAN & $<0.0625$ & 19.33 & 22.74
\end{tabular}

Data points from graph of cumulative percent vs grain size in phi ( $\phi$ )

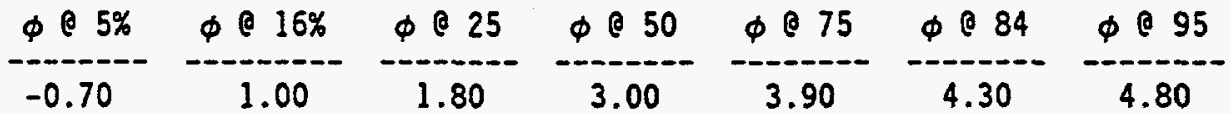

Statistical Parameters of Grain Size

Graphic Mean (Mz)

$=2.77 \phi=0.14 \mathrm{~mm}$

Fine sand

Inclusive Graphic Standard Deviation $\left(\mathrm{O}_{1}\right)=1.66 \phi=0.31 \mathrm{~mm}$ Poorly Sorted

Inclusive Graphic Skewness (Skl)

$=-0.28$ Coarse Skewed

Graphic Kurtosis (Ko)

Mesokurtic (normal distribution)

Pipette Analysis

\begin{tabular}{cc} 
Grain & $\begin{array}{c}\text { Weight } \\
\text { Percent }\end{array}$ \\
\hline $0.0020-0.0625$ (silt) & $\frac{15.49}{15 m}$ \\
$<0.0020$ (clay) & 7.25 \\
Total* & 22.74
\end{tabular}

* Pan fraction in sieve analysis, above.

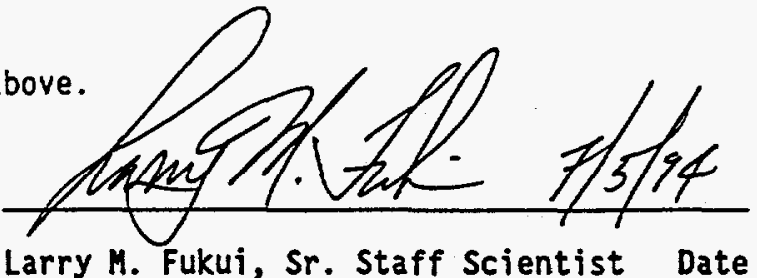




\section{GRAIN SIZE RESULTS}

\section{SAMPLE NCE 923}

REQUESTED BY: JIM ALLEN

PROJECT NO.: ARCMS2121

DATE: JULY 5, 1994
REQUISITIOH NO.: 12672

SITE: RABBIT VALLEY

PROCEDURE: SA-02-83, REV. 05

\section{Sieve Analysis}

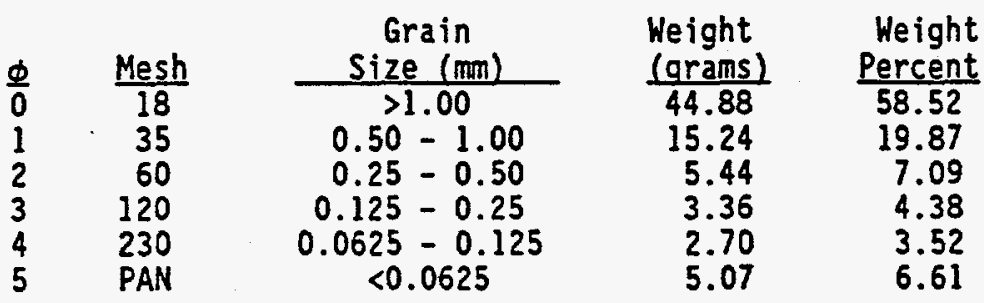

Data points from graph of cumulative percent vs grain size in phi ( $\phi$ )

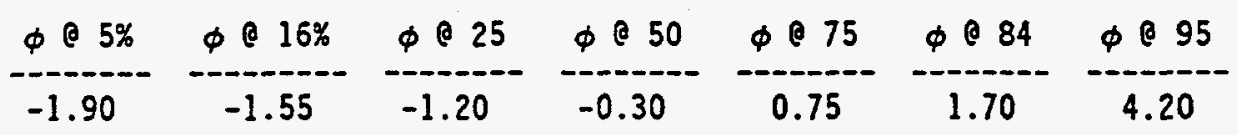

Statistical Parameters of Grain Size

Graphic Mean ( $\left.M_{z}\right)$ Very coarse sand (hard shale grains)

Inclusive Graphic Standard Deviation $\left(0_{1}\right)=1.74 \phi=0.29 \mathrm{~mm}$ Poorly sorted

Inclusive Graphic Skewness
Strongly fine skewed

Graphic Kurtosis $\left(K_{G}\right)$

$(S k !)=0.35$

Leptokurtic

$=1.28$

\section{Pipette Analysis}

$\begin{array}{cc}\begin{array}{c}\text { Grain } \\ \text { Size (mm) }\end{array} & \begin{array}{r}\text { Weight } \\ \text { Percent }\end{array} \\ 0.0020-0.0625(\mathrm{silt}) & 3.24 \\ 00.0020 \text { (clay) } & 3.37 \\ \text { Total* } & 6.61\end{array}$

* Pan fraction in sieve analysis, above.

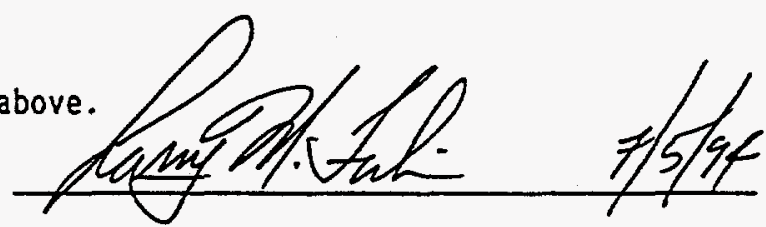

Larry M. Fukui, Sr. Staff Scientist Date 


\section{GRAIN SIZE RESULTS}

\section{SAMPLE NCE 924}

REQUESTED BY: JIM ALLEN

PROJECT NO.: 4RCMS2121

DATE: JULY 5, 1994
REQUISITION NO.: 12672

SITE: RABBIT VALLEY

PROCEDURE: SA-02-83, REV. 05

Sieve Analysis

\begin{tabular}{lr}
$\phi$ & Mesh \\
\hline 0 & 18 \\
1 & 35 \\
2 & 60 \\
3 & 120 \\
4 & 230 \\
5 & PAN
\end{tabular}

$$
\begin{gathered}
\text { Grain } \\
\text { Size (mm) } \\
\hline>1.00 \\
0.50-1.00 \\
0.25-0.50 \\
0.125-0.25 \\
0.0625-0.125 \\
<0.0625
\end{gathered}
$$

\begin{tabular}{|c|c|c|c|c|c|c|}
\hline $5 \%$ & $\phi \subset 16 \%$ & $\phi \odot 25$ & $\phi \odot 50$ & $\phi \subset 75$ & $\phi \subset 84$ & $\phi 95$ \\
\hline-0.60 & 0.45 & 1.30 & 2.90 & 4.05 & 4.40 & 4.80 \\
\hline
\end{tabular}

\begin{tabular}{cc}
$\begin{array}{c}\text { Weight } \\
\text { (grams) }\end{array}$ & $\begin{array}{r}\text { Weight } \\
\text { Percent }\end{array}$ \\
\hline 12.56 & 10.69 \\
12.96 & 11.03 \\
14.32 & 12.18 \\
20.61 & 17.54 \\
26.19 & 22.28 \\
30.89 & 26.28
\end{tabular}

Data points from graph of cumulative percent vs grain size in phi $(\phi)$

Statistical Parameters of Grain Size

Graphic Mean (Mz) Fine sand

Inclusive Graphic Standard Deviation $\left(\mathrm{O}_{l}\right)=1.81 \phi=0.28 \mathrm{~mm}$ Poorly sorted

\begin{tabular}{|c|c|}
\hline $\begin{array}{l}\text { Grain } \\
\text { Size }(\mathrm{mm})\end{array}$ & $\begin{array}{l}\text { Weight } \\
\text { Percent }\end{array}$ \\
\hline $\begin{array}{l}0.0020-0.0625(\mathrm{silt}) \\
<0.0020(\mathrm{clay}) \\
\text { Total* }^{*}\end{array}$ & $\begin{array}{r}17.83 \\
8.45 \\
26.28\end{array}$ \\
\hline
\end{tabular}

Inclusive Graphic Skewness (Sk:) Coarse skewed

Graphic Kurtosis $\left(K_{0}\right)$ Platykurtic

Pipette Analysis

* Pan fraction in sieve analysis, above.
$=-0.27$

$=0.80$

$$
0.27
$$

$=2.58 \phi=0.17 \mathrm{~mm}$ 